\title{
ECOLOGY, TAXONOMIC STATUS, AND CONSERVATION OF THE SOUTH GEORGIAN DIVING PETREL (Pelecanoides georgicus) IN NEW ZEALAND
}

BY

JOHANNES HARTMUT FISCHER

\author{
A thesis \\ submitted to Victoria University of Wellington \\ in fulfilment of the requirements for the degree of \\ Master of Science in Conservation Biology
}

School of Biological Sciences

Faculty of Sciences

Victoria University of Wellington

September 2016 


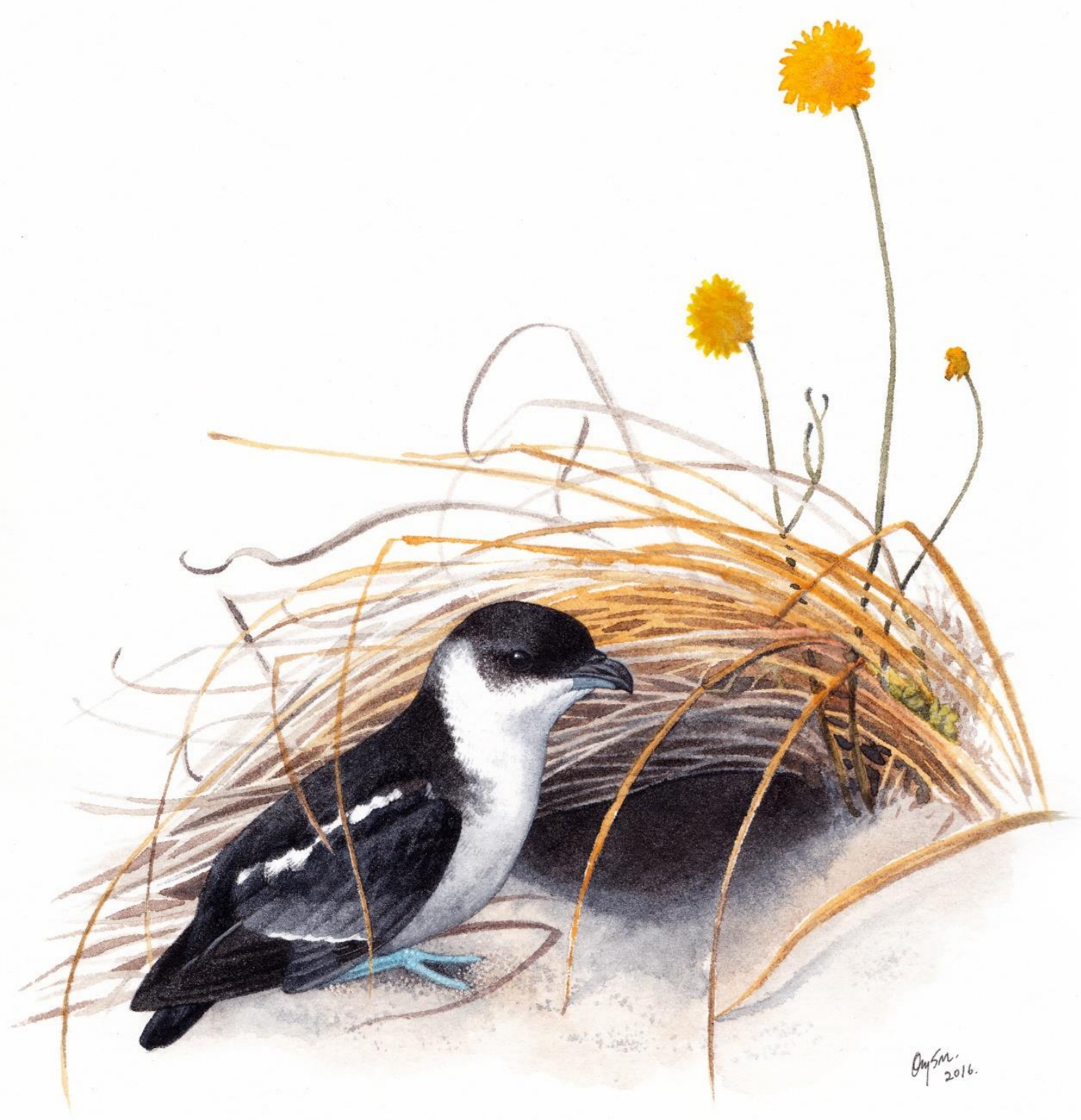

\section{Supervisor:}

Dr. Heiko U. Wittmer,

Senior Lecturer at the School of Biological Sciences, Victoria University of Wellington.

(C) Johannes Hartmut Fischer. September 2016. Ecology, Taxonomic Status and Conservation of the South Georgian Diving Petrel (Pelecanoides georgicus) in New Zealand. 


\section{ABSTRACT}

$\mathrm{P}$ ROCELLARIFORMES IS A diverse order of seabirds under considerable pressure from onshore and offshore threats. New Zealand hosts a large and diverse community of Procellariiformes, but many species are at risk of extinction. In this thesis, I aim to provide an overview of threats and conservation actions of New Zealand's Procellariiformes in general, and an assessment of the remaining terrestrial threats to the South Georgian Diving Petrel (Pelecanoides georgicus; SGDP), a Nationally Critical Procellariiform species restricted to Codfish Island (Whenua Hou), post invasive species eradication efforts in particular. I reviewed 145 references and assessed 14 current threats and 13 conservation actions of New Zealand's Procellariiformes $(n=48)$ in a meta-analysis. I then assessed the terrestrial threats to the SGDP by analysing the influence of five physical, three competition, and three plant variables on nest-site selection using an information theoretic approach. Furthermore, I assessed the impacts of interspecific interactions at 20 SGDP burrows using remote cameras. Finally, to address species limits within the SGDP complex, I measured phenotypic differences (10 biometric and eight plumage characters) in 80 live birds and 53 study skins, as conservation prioritisation relies on accurate taxonomic classification. The results from the meta-analysis revealed that New Zealand's Procellariiformes are at risk from various threats $(\bar{x}=5.50 \pm 0.34)$, but species also receive aid from several conservation actions $(\bar{x}=7.19 \pm 0.33)$. Results from a logistic regression showed that smaller species are more threatened onshore than offshore. The majority of the conservation actions appear in place where needed. However, habitat management, native predator control and the mitigation of risks associated with environmental stochasticity may need improvement. Analysis of SGDP nest-site selection showed dependency on mobile, steep, seaward-facing foredunes. Invasive plant species, the presence of conspecifics, or the presence of other seabird species did not influence SGDP nest-site selection. Assessment of interspecific interactions at SGDP burrows showed seven species occurring at burrows, but only Common Diving Petrels (P. urinatrix; CDP) interfered with SGDP breeding success. Assessment of phenotypic differences within the SGDP revealed that the New Zealand SGDP population differs in five biometric and three plumage 
characters from all other populations and warrants species status based on a species delimitation test with quantitative criteria. I propose to name this Critically Endangered species Pelecanoides taylorii sp. nov. These findings indicate that $P$. taylorii is of considerable conservation concern and additional measures, even after successful eradication of invasive species, may be required to safeguard this species. Based on the habitat preference, stochastic events, such as storms and storm surges, appear a major threat to $P$. taylorii. The assessed interspecific interactions at nestsites, indicate competition with CDPs to be a minor threat. I propose a translocation as a potential strategy to relieve the pressure on P. taylorii, but further monitoring and research is needed to enable the implementation of such a conservation strategy. 


\section{ACKNOWLEDGEMENTS}

THIS RESEARCH WAS generously supported by the New Zealand Department of Conservation (DOC), the Ornithological Society of New Zealand (OSNZ) through the Birds NZ Research Fund 2015, the Dunes Restoration Trust of New Zealand through the Dunes Trust Postgraduate Student Study Award 2016, the Centre for Biodiversity and Ecological Restoration (CBRE), the Australasian Seabird Group (ASG) through the Student Grant 2016, and the Hutton's Shearwater Charitable Trust.

My first and biggest thank you goes to Dr. Heiko U. Wittmer for his supervision and his unwavering belief in both my project and me. Dr. Igor Debski and Graeme Taylor also have my deepest gratitude for their advice and guidance. I am grateful to the Ngāi Tahu, DOC Southern Islands, and Kakapo Recovery for granting visits to Codfish Island (Whenua Hou). I thank Igor Debski, Graeme Miller, Juliet O'Connell, and a myriad of volunteers for their assistance in the field. I am grateful to Jake Tessler for assisting in designing and building burrow traps. The access to data from the Kerguelen Islands provided by Charles-André Bost, Ayemeric Fromant, and Colin Miskelly is much appreciated. I thank Alan Tennyson and Colin Miskelly for granting access to specimens at Te Papa Tongarewa Museum of New Zealand (NMNZ). I am most grateful to Peter Caipanolo, Paul R. Sweet, and Thomas J. Trombone from the American Museum of Natural History (AMNH), and Alex Bos, Hein van Grouw and Justin Jansen from the Natural History Museum (BMNH) for the provision of data from museum specimens. I thank Victor Anton, Sandy Bartle, Katherine Clements, Stu Cockburn, Graeme Elliott, Stephen Hartley, Jo Hiscock, Wei Ji Leong, Les McPherson, Jason Preble, Matt Rayner, Bruce Robertson, Rachael Sagar, Sharon Trainor, Jake Tessler, Murray Williams, and Samhita Yumnam for further insights and advice. Furthermore, I am grateful to Francesco Angeloni, Victor Anton, Igor Debski, Hartmut Fischer, Sabine Fischer, Ellen Irwin, Justin Jansen, Regan Mackinley, Jason Preble, Graeme Taylor, and Bibek Yumnam for proofreading various manuscripts. Finally, I am indebted to David Young for providing the electronic artwork, and to Ayuwat Jearwattanakanok for providing the frontispiece. 


\section{CONTENTS}

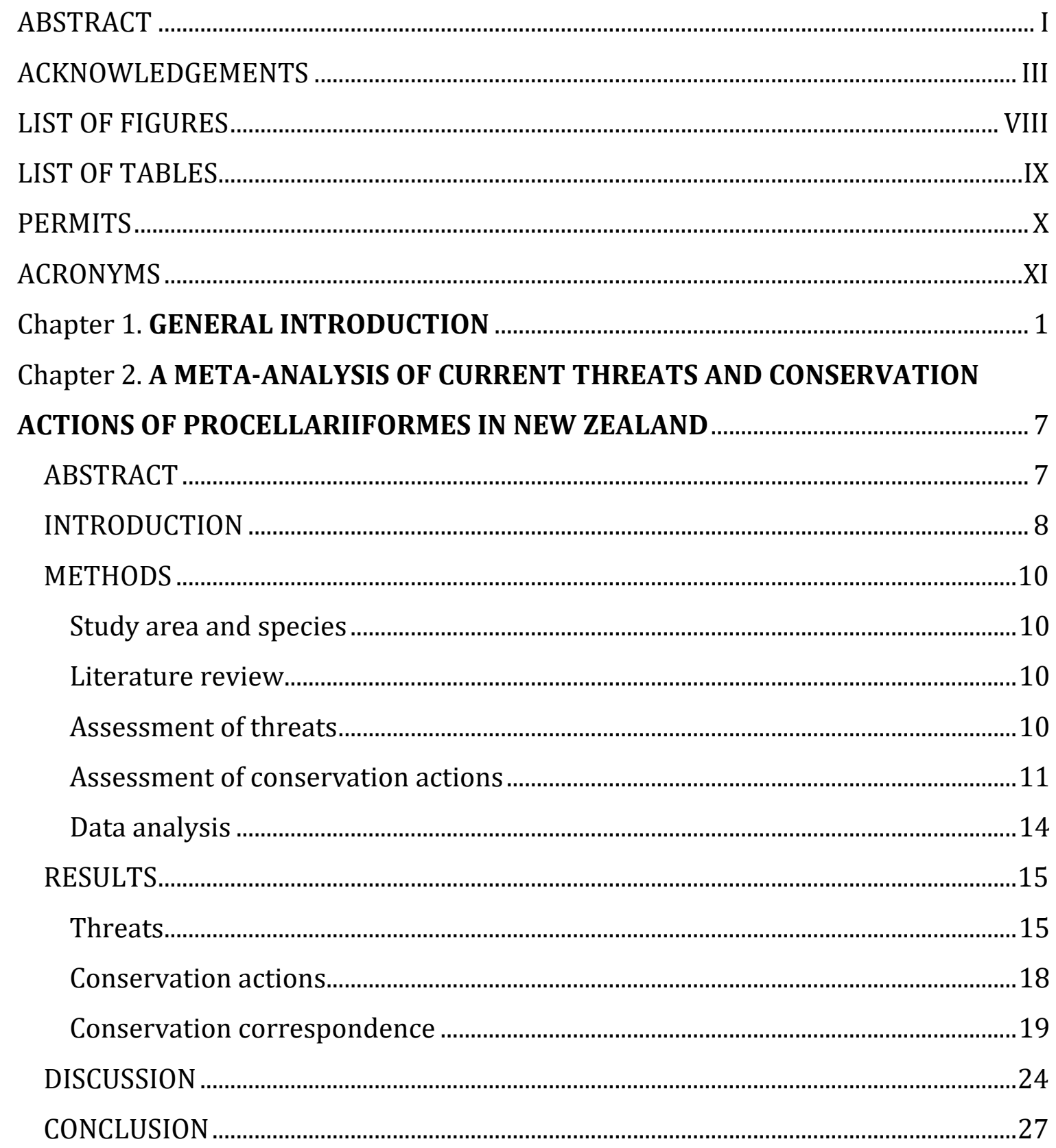

Chapter 3. NEST-SITE SELECTION OF SOUTH GEORGIAN DIVING PETRELS ON CODFISH ISLAND, NEW ZEALAND: IMPLICATIONS FOR CONSERVATION

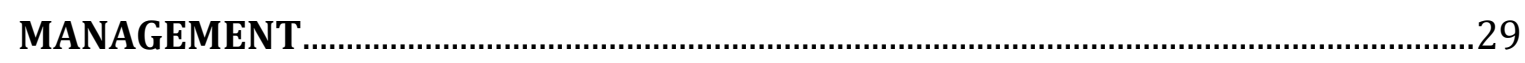

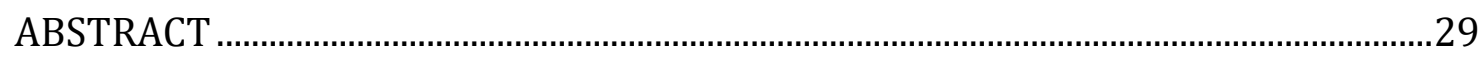

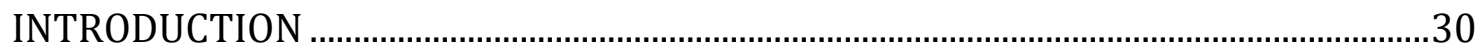

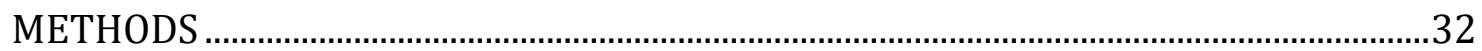

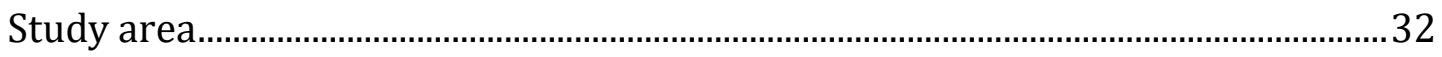




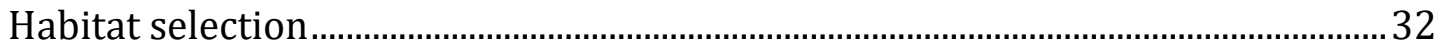

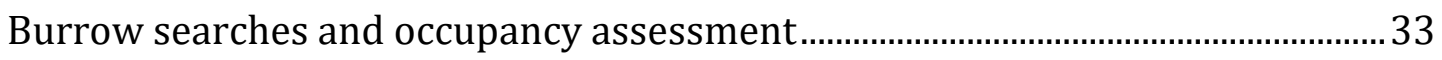

Variables affecting nest-site selection............................................................................... 33

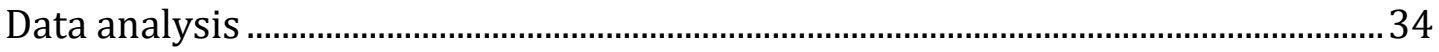

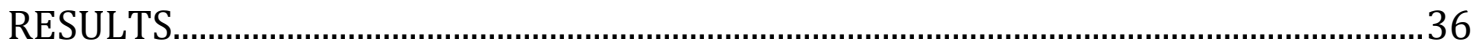

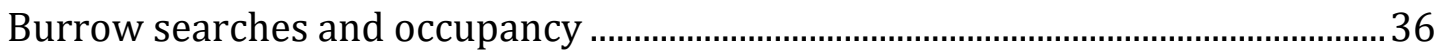

Relative importance of variables in the whole dune system .....................................36

Relative importance of variables in the foredune ...........................................................39

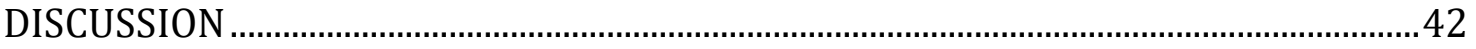

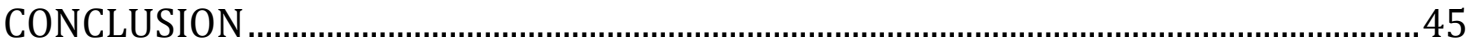

Chapter 4. ASSESSING THE SUITABILITY OF NON-INVASIVE METHODS TO

MONITOR INTERSPECIFIC INTERACTIONS AND BREEDING BIOLOGY OF THE

SOUTH GEORGIAN DIVING PETREL........................................................................... 47

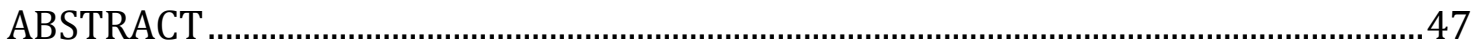

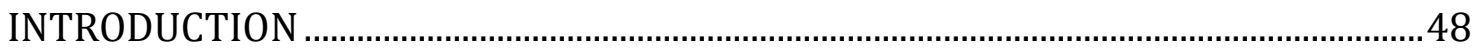

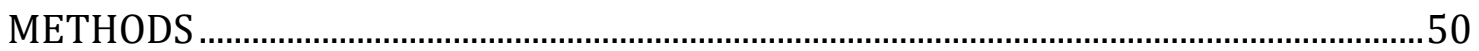

Study area

Assessment of burrow occupancy and breeding success...........................................50

Remote camera pilot study............................................................................................. 50

Assessment of interactions at burrows ……….......................................................... 51

Assessment of remote cameras for monitoring ……..................................................... 51

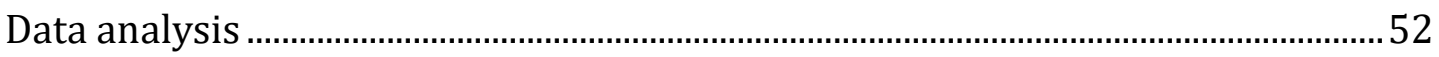

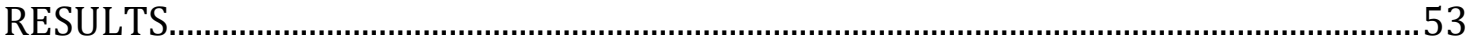

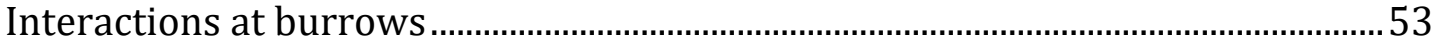

Detection rate of remote cameras …………................................................................ 55

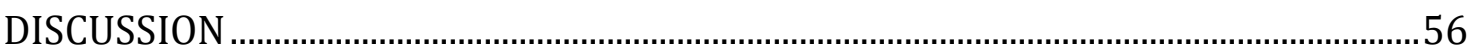

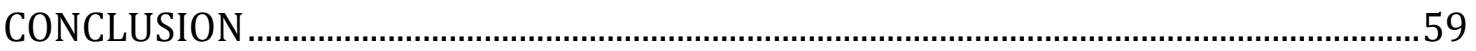

Chapter 5. ANALYSIS OF PHENOTYPIC DIFFERENTIATIONS BETWEEN SOUTH GEORGIAN DIVING PETREL (Pelecanoides georgicus) POPULATIONS REVEALS AN UNDESCRIBED AND HIGHLY ENDANGERED SPECIES FROM NEW ZEALAND61

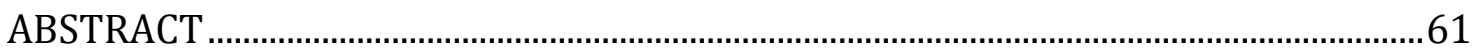

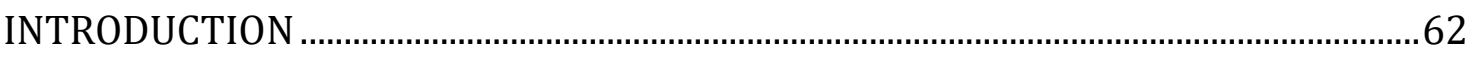

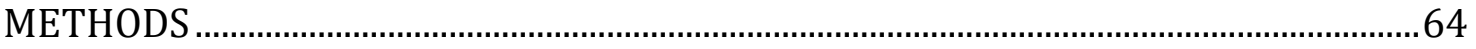




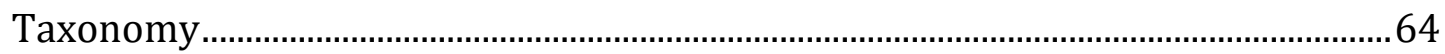

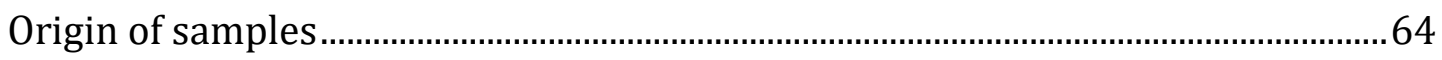

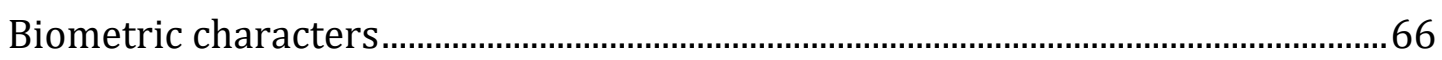

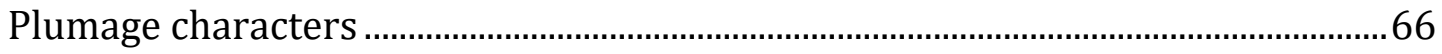

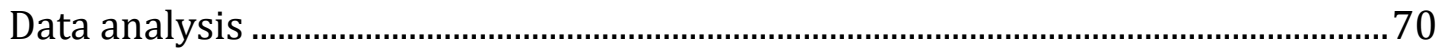

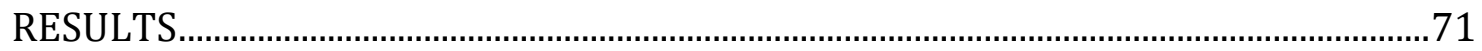

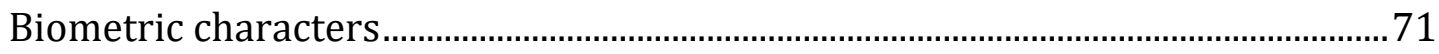

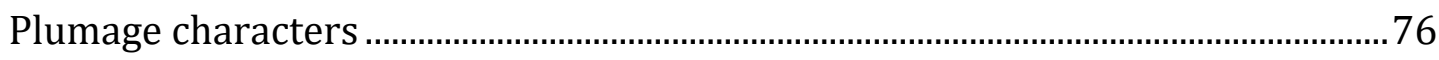

Phenotypic species delimitation test............................................................................. 76

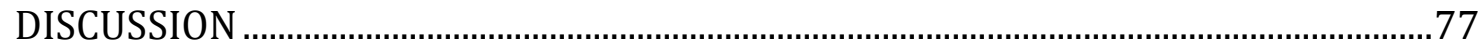

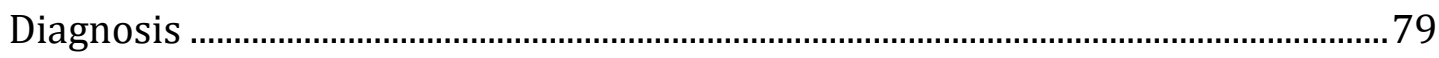

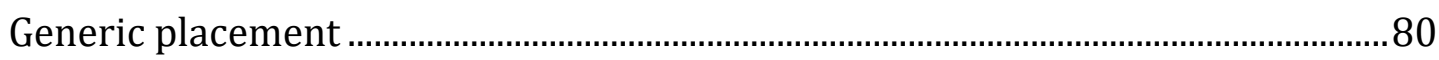

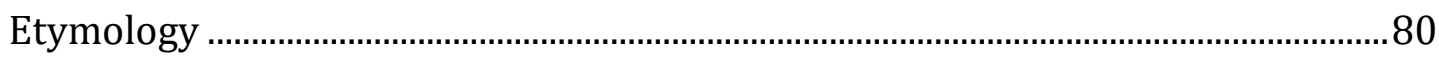

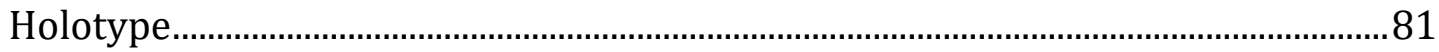

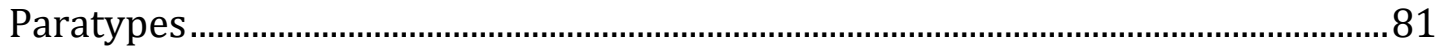

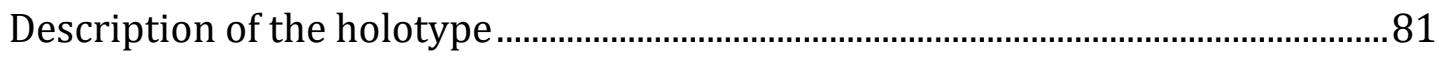

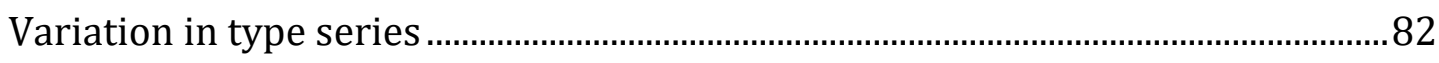

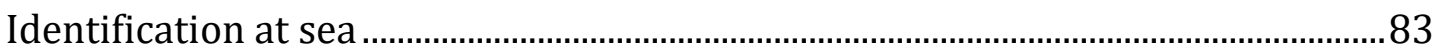

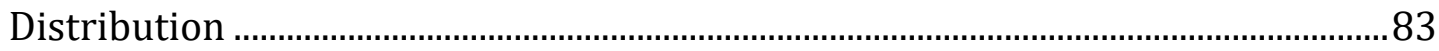

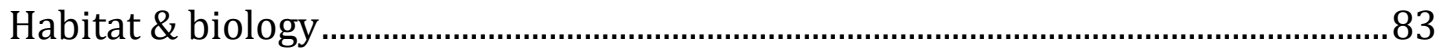

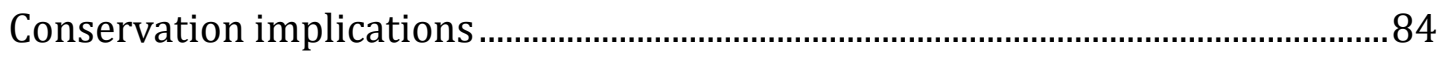

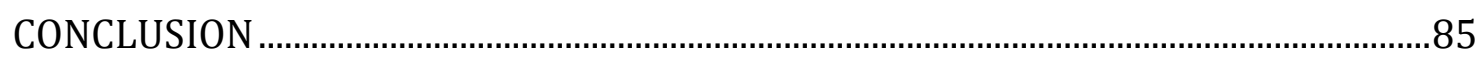

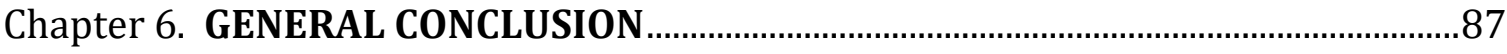

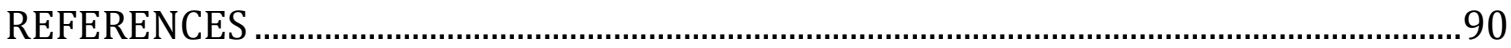

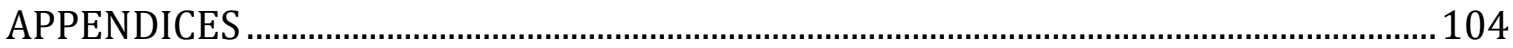

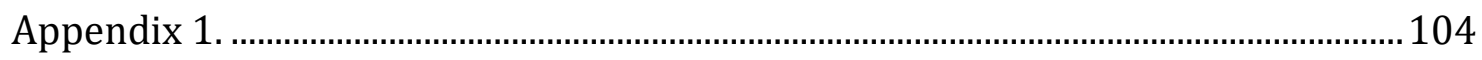

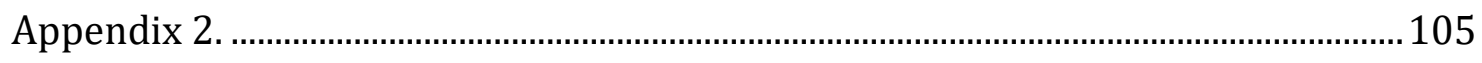

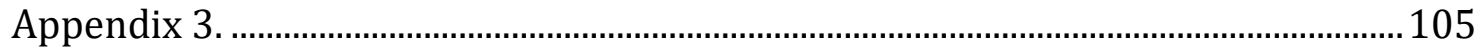

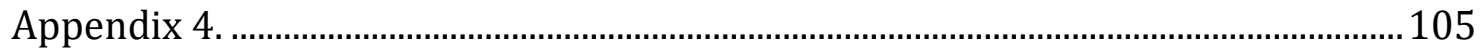

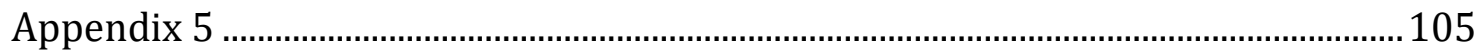




\section{LIST OF FIGURES}

Figure 1.

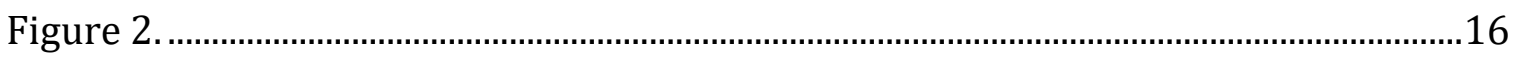

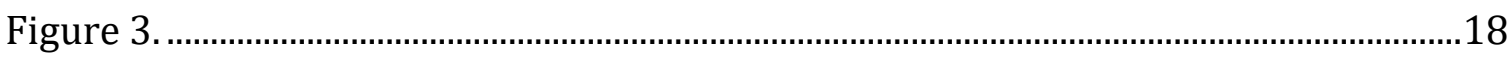

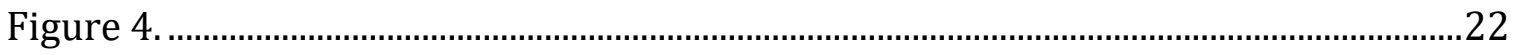

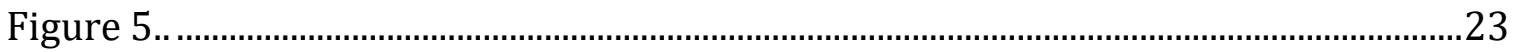

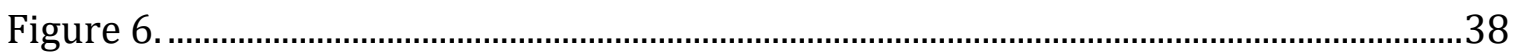

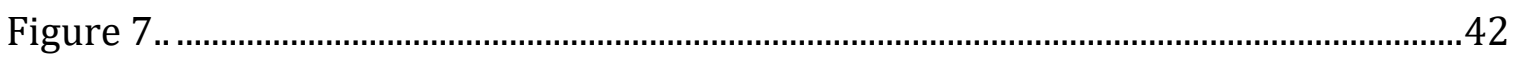

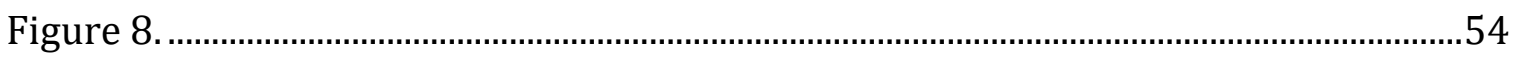

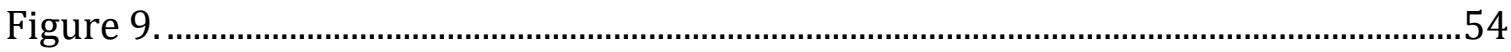

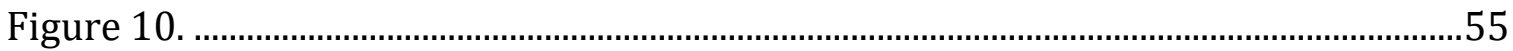

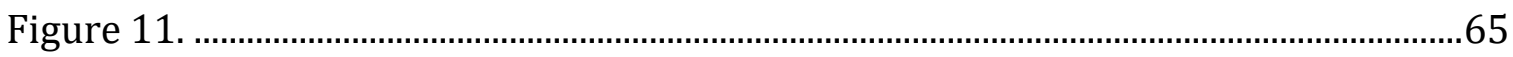

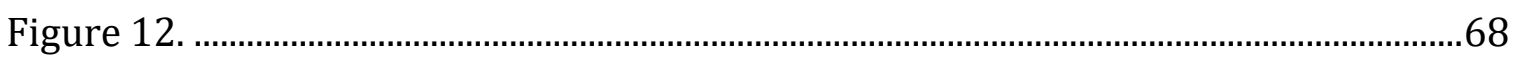

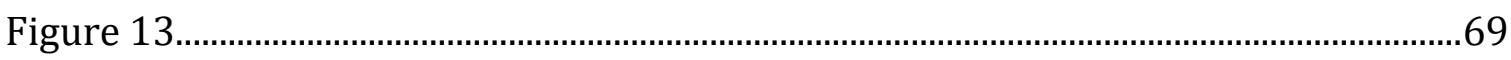

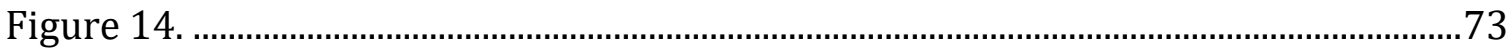

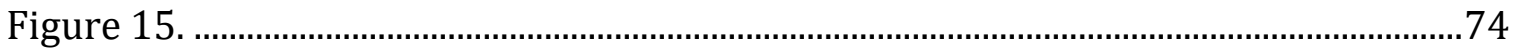




\section{LIST OF TABLES}

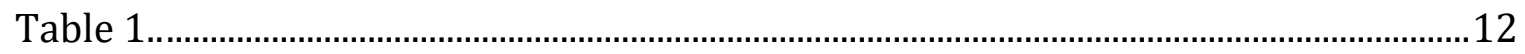

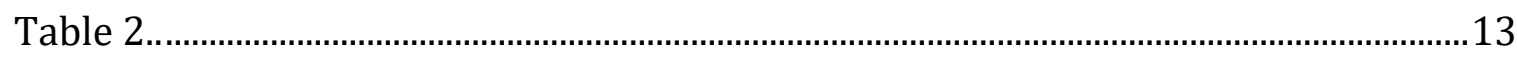

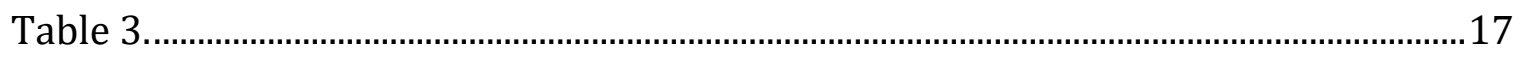

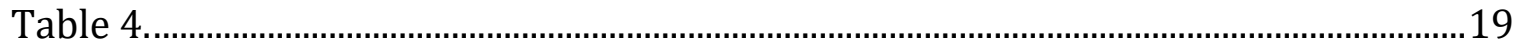

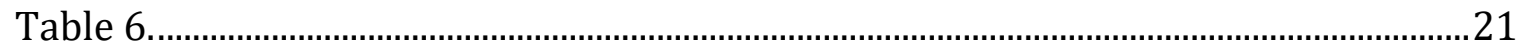

Table 5

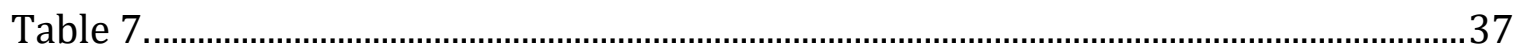

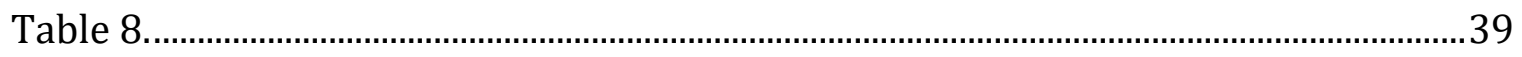

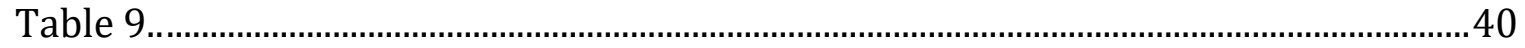

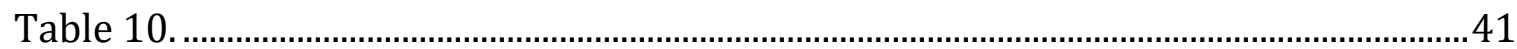

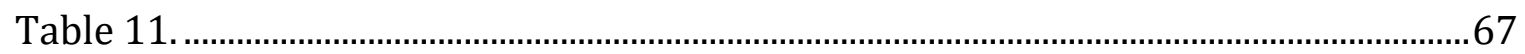

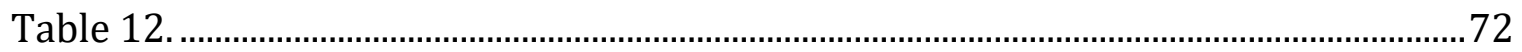

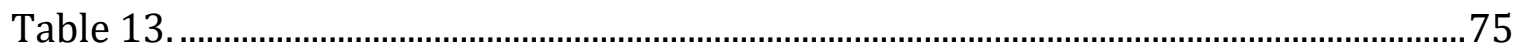

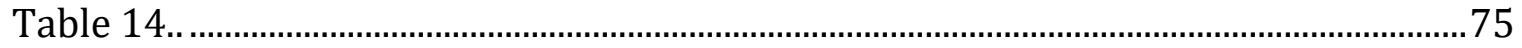




\section{PERMITS}

LL USED METHODS were approved by the Victoria University of Wellington
Animal Ethics Committee (VUW AEC 22252), the Department of Conservation (Wildlife Authority Act 45407-FAU \& Entry Permit 47920-LND-1516/04) and the Whenua Hou Committee. 


\section{ACRONYMS}

AICc Akaike Information Criterion, corrected for small sample sizes

AIR Active Infrared

AMNH American Museum of Natural History, New York, U.S.A.

ANOVA Analysis of Variance

BMNH Natural History Museum, Tring, U.K.

CDP Common Diving Petrel (Pelecanoides urinatrix)

DOC New Zealand Department of Conservation

GLM Generalised Linear Model

IUCN International Union for Conservation of Nature

LM Linear Model

LOESS Locally Estimated Scatterplot Smoothers

MCA Multiple Correspondence Analysis

NMNZ Te Papa Tongarewa Museum of New Zealand, Wellington, New Zealand

PCA Principal Component Analysis

PIR Passive Infrared

RFID Radio Frequency Identification

RVI Relative variable importance

SAO South Atlantic Ocean

SGDP South Georgian Diving Petrel (Pelecanoides georgicus)

SIO Southern Indian Ocean

SP0 South Pacific Ocean 
Chapter 1 


\section{Chapter 1.}

\section{GENERAL INTRODUCTION}

ONSERVATION BIOLOGY IS the science aimed at countering the human-induced,
cataclysmic mass-extinction. Anthropogenic changes to the environment have had unprecedented impacts on the biosphere, resulting in extinction rates 100 to 1000 times higher than pre-human rates (Pimm et al. 1995, Hoffmann et al. 2010). These human-induced changes are not only apparent on a global scale, but also occur within a relatively small timeframe (Pimm et al. 1995). Numerous species are on the brink of extinction due to these wide-ranging, rapid changes. The IUCN (2016) lists 4749 species that are at extremely high risk (i.e. Critically Endangered), 7050 species at very high risk (i.e. Endangered) and 10,694 species at high risk (i.e. Vulnerable) of extinction. Conservation biology aims to prevent the extinction of these and other species, and while extinction rates are increasing, conservation efforts are slowing the rate of increase (Hoffman et al. 2010). However, given the vast number of threatened species and the limited resources at hand, conservation prioritisation is challenging (Brooks et al. 2006).

Procellariiformes is a severely threatened order of seabirds, whose members are ecosystem engineers - species with a disproportionate influence on the surrounding environment - and thus of high conservation interest. The order Procellariiformes is diverse and encompasses approx. 100 seabird species, including some of the largest (Albatrosses) and some of the smallest seabird species (e.g., Storm Petrels) (Marchant \& Higgins 1990, Gill et al. 2010). Procellariiform species are distributed throughout the world's oceans, but most species occur in the southern hemisphere (Marchant \& Higgins 1990). Procellariiformes is one of the most threatened bird orders (Butchart et al. 2004, Croxall et al. 2012) and the life history traits of these species (slow population growth rates, small clutch sizes, and long incubation and chick rearing stage; $K$-strategy) render these species particularly prone to extinctions (Duncan \& Blackburn 2004, Satterthwaite \& Mangel 2012). Consequently, a substantial percentage ( $43 \%$ ) of Procellariiform species is currently threatened with extinction (IUCN 2016). Some of these species rank among the rarest and most threatened birds in the world, as 12 species are listed as Critically 
Endangered. This is of major conservation concern, as Procellariiformes enable nutrient cycling between terrestrial and pelagic ecosystems, alter soil properties through bioturbation, and influence the vegetation in their breeding colonies. (Sekercioglu et al. 2004, Hawke \& Holdaway 2005, Paleczny et al. 2015). The presence of these birds also enhances the diversity of invertebrates and reptiles (Markwell \& Daugherty 2002). Furthermore, these birds act as seed dispersers (Falla 1960, Cheke \& Hume 2010). Moreover, Procellariiformes are considered indicators of various ecosystem changes because of their placement on high trophic levels, large ranges and long lifespans (Furness \& Camphuysen 1997, Paleczny et al. 2015).

New Zealand is of global conservation importance to Procellariiformes. New Zealand hosts one of the most diverse communities and the highest number of endemic species of Procellariiform of any country (Taylor 2000, Croxall et al. 2012). Currently four families encompassing 48 different Procellariiform species breed within the boundaries of New Zealand, of which 18 are endemic to the area (Taylor 2000, Gill et al. 2010). Another approximately 30 species visit New Zealand's waters as passage migrant, winter visitor or vagrant (Gill et al. 2010, Heather \& Robertson 2015). Procellariiform species in New Zealand have suffered significant population declines due to anthropogenic influences (Taylor 2000) and at least two species have been extirpated following human settlement (Tennyson et al. 2015). Various methods are used to conserve New Zealand's Procellariiform species (e.g., Miskelly et al. 2009, Gummer et al. 2015, Jones et al. 2016). Yet most species are still under considerable pressure from both onshore and offshore threats (Taylor 2000) and 18 species breeding in New Zealand are considered at direct risk of extinction (IUCN 2016). The New Zealand Department of Conservation (DOC) also maintains a national threat ranking system and this ranks 11 Procellariiform species as Nationally Critical, Nationally Endangered or Nationally Vulnerable (Robertson et al. 2013).

Caughley (1994) identified two paradigms within conservation biology: the small and the declining population paradigm. The first is involved with identifying and mitigating the negative effects caused by the small size of a population (e.g., inbreeding or stochasticity). The second is concerned with the causes of the population decline (e.g., overkill or habitat loss). Invasive species also fall under the declining population paradigm (Caughley 1994) and are part of Diamond's (1984) "evil quartet" of extinction drivers. Predation by invasive species represents one of 
the main causes of Procellariiform population declines in New Zealand (Taylor 2000). New Zealand has successfully eradicated invasive species on increasingly large islands (Towns \& Broome 2003, Jones et al. 2016). Such eradications had a variety of beneficial outcomes for Procellariiformes, including the release of habitat constraints and population increases (Taylor 2000, Middleton 2007, Rayner et al. 2008, Buxton et al. 2015, Jones et al. 2016). However, other threats, besides invasive species, within both the small and the declining population paradigm, may also imperil New Zealand's Procellariiformes (Taylor 2000).

An example of a highly threatened Procellariiform taxon in New Zealand is the South Georgian Diving Petrel (Pelecanoides georgicus; SGDP). This small species (90$160 \mathrm{~g}$; Taylor \& Cole 2002) has a wide distribution across the southern oceans and is considered Least Concern by the IUCN (2016). The SGDP was also widespread and numerous in southern New Zealand (Figure 1), but the species has been affected by local extinctions throughout the majority of its historic range and the species was extirpated on the Auckland Islands (Dundas and Enderby Island), Chatham Islands, Stewart Island (Mason Bay) and the Otago Peninsula (Sandfly Bay) (Marchant \& Higgins 1990, Worthy 1998, Taylor 2000, Holdaway et al. 2003, Wood \& Briden 2008). The last remaining SGDP population in New Zealand persists in the Sealers Bay dunes of Codfish Island (Whenua Hou) and numbers approximately 150 individuals only (Wood \& Briden 2008, Taylor 2013). This precarious state has resulted in the species being listed as Nationally Critical (Robertson et al. 2013). Invasive species have been eradicated from Codfish Island, partly to aid the various Procellariiform populations present on the island (Middleton 2007). No distinct population increase has been observed for the SGDP population post eradication efforts (Taylor 2000, Wood \& Briden 2008, Taylor 2013), which contrasts with the responses observed in other Procellariiform species present on the island (Middleton 2007, Rayner et al. 2008). Consequently, other inhibiting factors may be limiting the SGDP population on Codfish Island. Various threats have been hypothesised, including the encroachment of the Sealers Bay dunes (Taylor 2013), erosion caused by stochastic events and catastrophes (Cole 2004), predation by Moreporks (Ninox novaeseelandiae) (Trainor 2008) and competition with Common Diving Petrels (P. urinatrix; CDP) for nest-sites (Taylor \& Cole 2002). No offshore threats affecting the SGDP are currently recognised, but collision with ships has been reported at other colonies (Black 2005). Moreover, 
the SGDP population on Codfish Island might be the last population of an undescribed species (Paterson et al. 2000). Consequently, the last remaining SGDP population in New Zealand may be of considerable global conservation concern.

The objective of this study is to provide further insights on the threats and conservation of New Zealand's Procellariiformes in general, and the ecology, current risks and taxonomic status of the SGDP in New Zealand in particular. In Chapter 2, I present a meta-analysis investigating the current threats and conservation actions of New Zealand's Procellariiformes. In Chapter 3, I analyse the nest-site selection of the SGDP on Codfish Island and infer terrestrial threats to the population. In Chapter 4, I assess interspecific interactions at SGDP burrows and their effects on SGDP breeding success with remote cameras. In addition, I assess the utility of remote cameras for breeding biology studies. In Chapter 5, I analyse phenotypic differences between SGDP populations and assess the taxonomic status of the Codfish Island SGDP population. I use the results presented in these chapters to discuss the potential directions for future conservation management in order to reinstate population growth, and ultimately, securing the SGDP population in New Zealand (Chapter 6). 


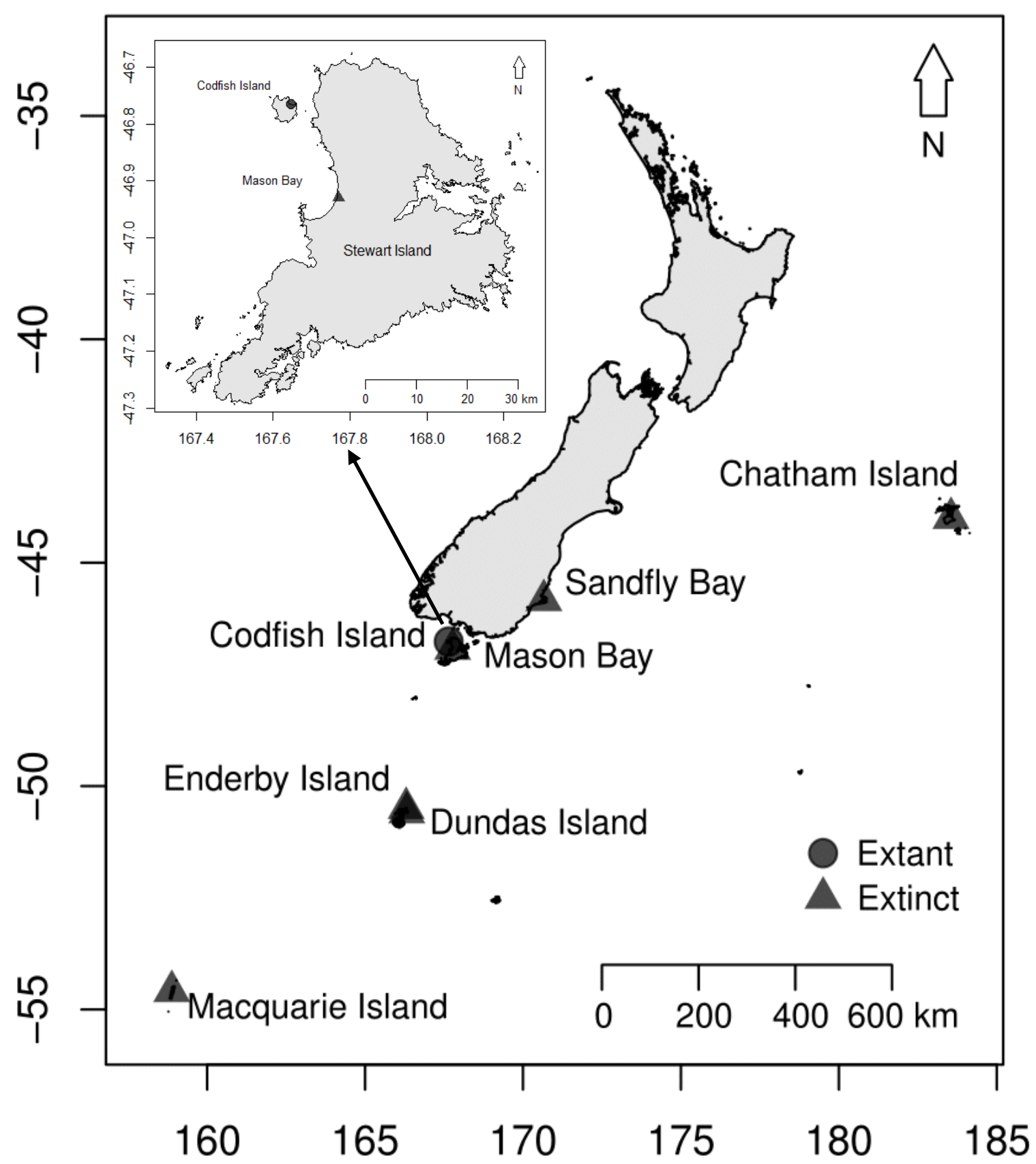

Figure 1. Historic and present distribution of the South Georgian Diving Petrel in southern New Zealand (including Macquarie Island, Australia). 
Chapter 2 
Chapter 2.

\section{A META-ANALYSIS OF CURRENT THREATS AND CONSERVATION ACTIONS OF PROCELLARIIFORMES IN NEW ZEALAND}

\section{ABSTRACT}

LARGE PORTION of the world's Procellariiformes breeds in New Zealand and
many of these are threatened with extinction. As these species are faced with an array of threats that occur in different ecosystems, implementation of conservation management can be challenging. To provide an overview and to inform management, I assessed current threats and conservation actions of New Zealand's Procellariiform species (families Diomedeidae, Procellariidae, Hydrobatidae and Pelecanoididae; $\mathrm{n}=$ 48). I reviewed 145 relevant references and constructed presence/absence databases of 14 threats and 13 conservation actions. Using these databases as a foundation for a meta-analysis, I showed that several threats imperil individual species $(\bar{x}=5.50 \pm$ $0.34)$, but species also benefited from a range of conservation actions $(\bar{x}=7.19 \pm 0.33)$. Invasive species ( $\mathrm{n}=42$ affected species), line fisheries $(\mathrm{n}=36)$ and net fisheries $(\mathrm{n}=$ 35) are the most commonly recognized threats. The most common conservation actions are bycatch management $(n=48)$, population census/survey $(n=48)$ and research investigating population dynamics and breeding biology $(n=46)$. Results of a logistic regression (GLM) illustrate that larger species are more likely to be threatened offshore, while smaller species are more often threatened onshore $\left(R^{2}\right.$ McFadden $\left.=0.254\right)$. In addition, I used Fisher's exact tests, Spearman correlation tests and multiple correspondence analyses (MCA) to test for correlation and correspondence between certain threats and conservation actions. These reveal that the majority of conservation actions are in place where needed. Improvements could be made in addressing negative effects caused by native predators ( $p=0.354$ ) and environmental stochasticity $(p=0.214)$, and potentially habitat loss. While the qualitative meta-analysis presented here provides a broad overview for New Zealand's Procellariiformes, further monitoring and research is needed to assess the quantitative effects of threats and conservation actions. 
Chapter 2

\section{INTRODUCTION}

Seabirds have a relatively low diversity (approx. 350 species) compared to other species groups (e.g., songbirds with approx. 5000 species) (Croxall et al. 2012, Moyle et al. 2016). Despite this low diversity, seabirds have attracted a considerable amount of attention on a global scale (Croxall et al. 2012). A possible explanation for this interest in seabirds may be that they are considered reliable indicators of ecosystem changes on large temporal and geographical scales, because most species are wideranging, long-lived, and placed on high trophic levels (Furness \& Camphuysen 1997, Paleczny et al. 2015). In addition, seabirds fulfil important ecosystem functions, as they can act as ecosystem engineers and increase nutrient cycling between ecosystems (Sekercioglu et al. 2004, Paleczny et al. 2015). The presence of seabirds also boosts the diversity of other species groups (Markwell \& Daugherty 2002). Unfortunately, Paleczny et al. (2015) showed that seabird populations suffered a global decrease of $70 \%$ in the last 60 years and consequently, many seabird species are currently threatened with extinction (IUCN 2016).

Seabirds spend most of their time foraging at sea, but return to land to breed and, for some species, to roost, and thus they are influenced by a variety of onshore and offshore threats. One of the main perils at sea is the accidental bycatch by commercial longline and trawl fisheries, which causes the death of several 100,000 seabirds each year (Tuck et al. 2003, Abraham \& Thompson 2011, Maree et al. 2014, Rollinson et al. 2014). In addition, ingestion of plastic debris (Fry et al. 1987, Wilcox et al. 2015) and contamination with chemical pollutants (Furness \& Camphuysen 1997, Chu et al. 2015) have been identified as offshore threats to many seabird species. A prevalent terrestrial threat to seabirds is predation of eggs, chicks and, sometimes, adults, by invasive mammalian species such as rats (Rattus ssp.) (Jones et al. 2007) or cats (Felis catus) (Keitt et al. 2002). Much effort has been invested to eradicate such problematic species (e.g., Towns \& Broome 2003, Phillips 2010, Jones et al. 2016). Furthermore, seabirds are also threatened onshore by the loss of suitable nesting habitat (Croxall et al. 2012) and human disturbance (Higham 1998) among others.

New Zealand contains the one of the most diverse seabird communities in the world (Taylor 2000) and was listed by Croxall et al. (2012) as the most threatened 
community in the world. Furthermore, New Zealand hosts the highest number of endemic seabird species $(\mathrm{n}=35)$ in the world (Taylor 2000, Croxall et al. 2012). The majority (58\%) of New Zealand's seabird species belong to the order Procellariiformes (Gill et al. 2010, Heather \& Robertson 2015). Many Procellariiformes are currently threatened with extinction. The IUCN (2016) has ranked 12 species as Critically Endangered, 18 as Endangered and 30 as Vulnerable. A considerable proportion of these threatened species breeds in New Zealand (2, 3, and 13, respectively). The New Zealand Department of Conservation (DOC) also maintains a national threat classification system (Robertson et al. 2013). In this system five Procellariiformes were ranked as Nationally Critical, two as Nationally Endangered and four as Nationally Vulnerable. Both threat classification systems underline the importance of New Zealand for Procellariiformes and the need for their conservation.

Given the array of potential threats, directing conservation management to secure and protect Procellariiformes can be challenging. Many studies have focused on the effects of a single threat or conservation action for a single species (e.g., Bell et al. 2005, Keitt et al. 2006) and several studies have directed their attention towards patterns across several species (e.g., Jones et al. 2007, Abraham \& Thompson 2011). Yet such studies are often limited to threats within a single ecosystem. As Procellariiform species rely on two entirely different ecosystems, broader overviews may be required to ensure conservation actions are directed successfully.

Using a meta-analysis of published references, I provide a qualitative review of the spread and nature of current threats and conservation actions of all Procellariiformes breeding in New Zealand. Specifically, I aim to address the following questions: 1) How are current threats spread among New Zealand's Procellariiformes? 2) What is the relationship between body weight and threats? 3) How are current conservation actions are spread among New Zealand's Procellariiformes? 4) What is the relationship between body weight and the spread of conservation actions? 5) Are conservation actions targeted directly at mitigating particular threats? 
Chapter 2

\section{METHODS}

\section{Study area and species}

The geographical scope of this meta-analysis is limited to New Zealand and its marine territories. I defined this area as the mainland of New Zealand including offshore island such as the Kermadec, Chatham, Bounty, Auckland, Campbell and Snares Islands as well as the New Zealand Exclusive Economic Zone (EEZ).

I assessed 48 Procellariiform species, of which 18 are endemic breeders to New Zealand. These 48 species represented four families: Diomedeidae $(n=11)$, Procellariidae $(n=29)$, Hydrobatidae $(n=6)$ and Pelecanoididae $(n=2)$. I only included Procellariiformes taxa that breed successfully within the study area, following the taxonomy of Gill et al. (2010). Therefore, I excluded migrants, wintervisitors, or vagrants to New Zealand, as well as populations that breed outside of New Zealand. For polytypic species, I solely assessed taxa breeding in New Zealand. Furthermore, I limited the taxonomic scope of this study to species level, and thus jointly assessed different subspecies of polytypic species breeding in New Zealand.

\section{Literature review}

I used both Google Scholar and Web of Science to search for literature by using the English and scientific name of each of the 48 target species as search term. In addition, I used Taylor (2000), Miskelly (2013) and IUCN (2016) as a starting point for further literature searches to account for relevant grey literature, such as internal DOC reports, that are unlikely to be found through regular search engines. I did not include literature published before 2000 in order to limit the scope of this meta-analysis to current threats and conservation actions. In total, I reviewed 145 references published between 2000 and 2015 as the fundament of this meta-analysis (Appendix 1).

\section{Assessment of threats}

Based on the sourced literature, I constructed a presence/absence database with 14 categories of threats faced by New Zealand's Procellariiformes (Appendix 2). I considered seven categories to be onshore threats and five to be offshore threats (Table 1). I considered two additional threat categories to be neither land- nor sea- 
based (non-spatial). I also classified the area of the most detrimental threats (onshore/offshore) per species in order to gain a better understanding of the overall patterns in threats. I based this classification of severity on a combination of number of references, data quality and, where necessary, data on closely related species.

\section{Assessment of conservation actions}

I also constructed a presence/absence database with 13 conservation action categories to evaluate the spread of current conservation actions directed at New Zealand's Procellariiformes (Appendix 3). I considered six conservation actions to be land-based and five to be sea-based (Table 2). I considered two additional conservation actions to be neither onshore nor offshore actions (non-spatial). Furthermore, I assumed certain conservation action categories to be aimed to mitigate particular threat categories $(n=8)$. 


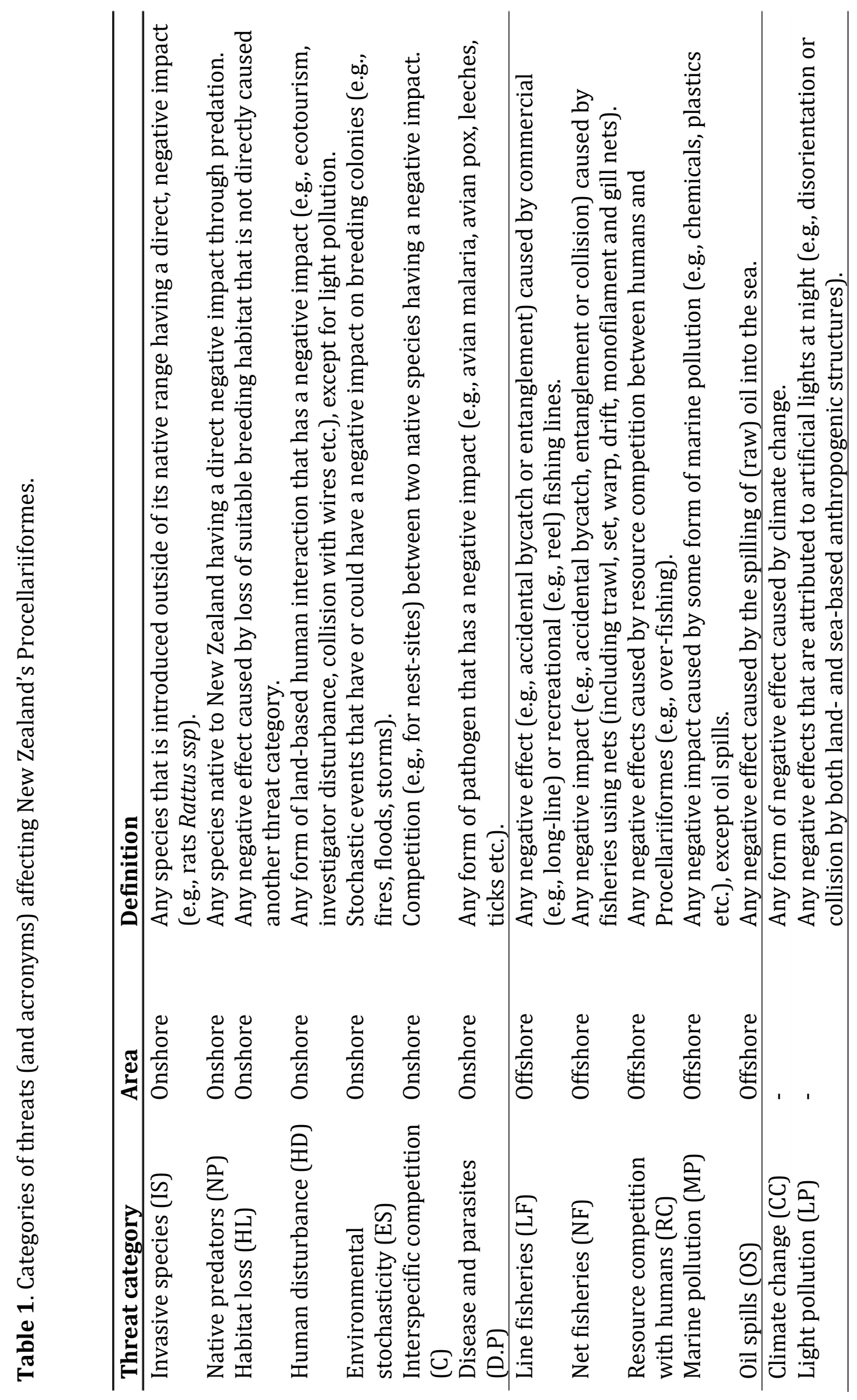




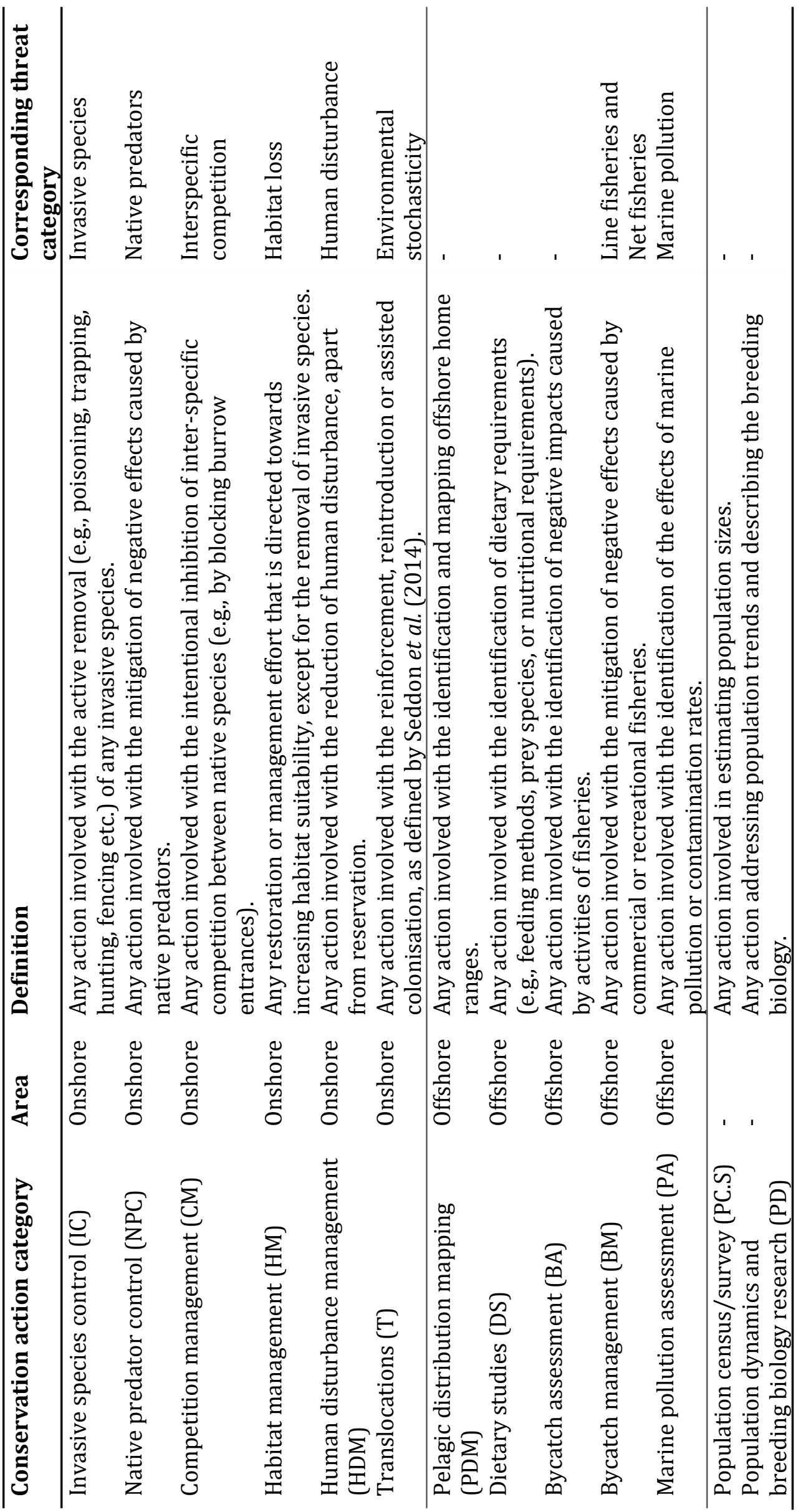


Chapter 2

\section{Data analysis}

I used the databases (Appendix $2 \& 3$ ) to assess patterns of threats and conservation actions of New Zealand's Procellariiformes. I analysed the differences in number of threats and conservation actions between families and endemics and non-endemics using factorial ANOVAs and Welch two-sample t-test, respectively. I excluded Pelecanoididae from these statistical analyses due to the low sample size $(n=2)$.

I analysed the relationship between body weight ( $\mathrm{g}$ ) and the number of threats, whether the most detrimental threats occurred onshore or offshore (main area of threats), and the number of conservation actions. For this, I sourced body weight data for each species from Scofield \& Stephenson (2013), del Hoyo et al. (2015) and Heather \& Robertson (2015). I then calculated the midpoint between the minimum and the maximum weight of each species. I calculated the midpoint as an approximation of the mean, because weight data of similar quality were not available for each species and I assumed that weight variation within species followed normal distribution. I then assessed the relationship between body weight and the main area of threats using a generalized linear model (GLM) with body weight as the independent and main area of threats as the dependent variable. I also assessed the relationship between the number of threats and conservation actions per species and body weight using linear models (LM).

I assumed that certain conservation action categories were directly aimed at the mitigation of certain threat categories. I therefore analysed how well these conservation action categories corresponded and correlated with their respective threat categories. First, I used Spearman correlation tests to assess correlation between threat and conservation action categories. Then I constructed contingency tables (based on presence/absence) and subsequently analysed these using Fisher's exact tests. I assumed bycatch management to aid all target species and thus this variable became a constant. Therefore, I excluded this variable from analyses with Fisher's exact tests and Spearman correlation tests. Finally, I performed two multiple correspondence analyses (MCA) to reduce dimensionality of variables and factors: one for onshore and one for offshore threats and conservation actions. I included nonspatial threats and conservation actions in both MCAs. 
I conducted all analyses in Program R (R Development Core Team 2016) using the Hmisc (Harrel 2016), the FactoMineR (Le et al. 2008) and the ggplot2 packages (Wickham 2009).

\section{RESULTS}

\section{Threats}

Threats that affect the most species of New Zealand's Procellariiformes are: invasive species ( $n=42$ affected species), line fisheries $(n=36)$, net fisheries $(n=35)$, environmental stochasticity $(n=30)$ and human disturbance $(n=29)$ (Figure 2). On average, species are threatened by $5.50 \pm 0.34$ different threats, of which $3.13 \pm 0.20$ are onshore, $1.94 \pm 0.20$ are offshore and $0.44 \pm 0.08$ are non-spatial threats (Table 3). The number of threats does not differ among Procellariiformes families overall $\left(f_{2,43}=0.928, p=0.403\right)$, onshore $\left(f_{2,43}=0.100, p=0.905\right)$ or offshore $\left(f_{2,43}=2.409, p\right.$ $=0.102$ ). Endemics and non-endemics also do not face significantly different number of threats overall $(t=-1.148, d f=37.137, p=0.259)$, onshore $(t=-0.866, d f=45.007$, $p=0.391)$ or offshore $(t=-1.297, d f=29.948, p=0.243)$.

The assessment of main area of threats shows that 32 species are primarily threatened by onshore threats, while 16 species were primarily threatened by offshore threats. The main area of threats has a very strong relationship with body weight $\left(R^{2}\right.$ McFadden $\left.=0.254\right)\left(R^{2}\right.$ McFadden $=0.2-0.4$ indicates excellent fit; Domencich \& McFadden 1975). With increasing body weight, the area of the most important threats shifts from onshore to offshore (Figure 3). Body weight of species is not related to the number of threats overall $\left(R^{2}=0.045, p=0.147\right)$, onshore $\left(R^{2}=0.010, p=0.502\right)$ or offshore $\left(R^{2}=0.061, p=0.091\right)$. 

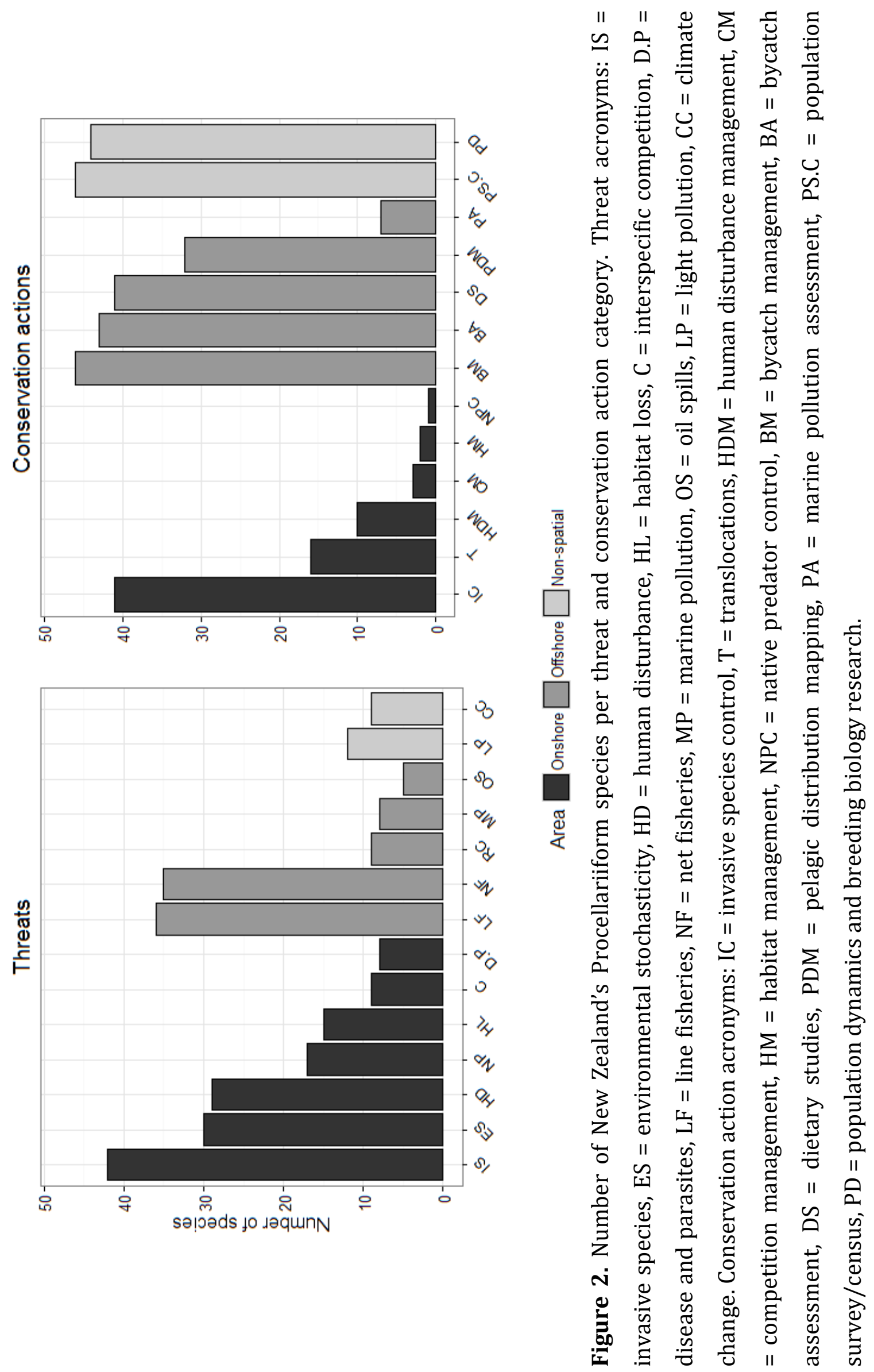

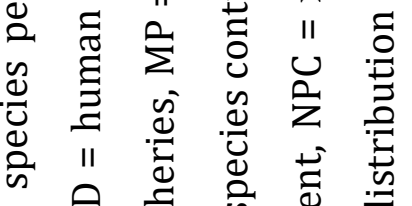




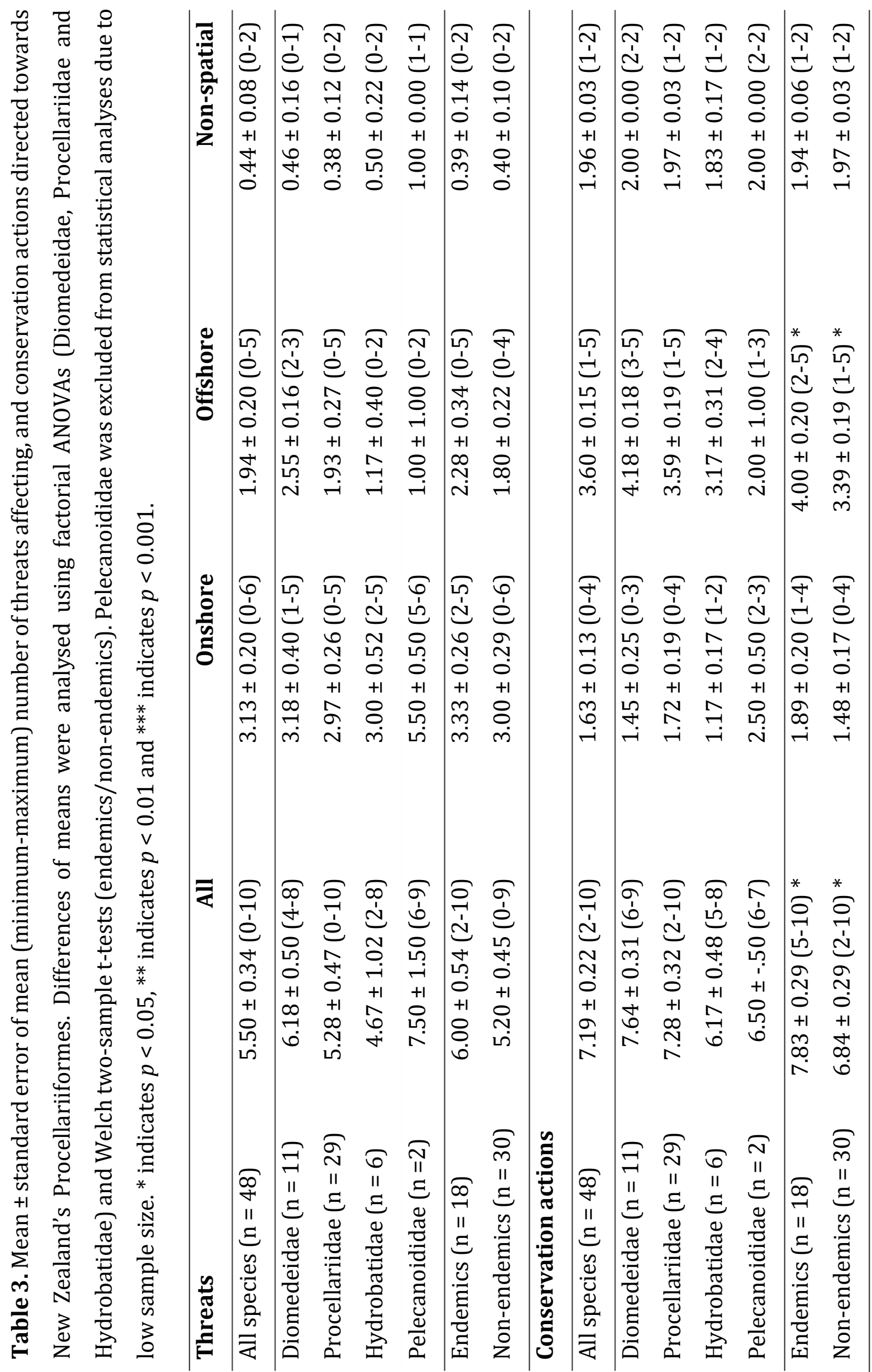




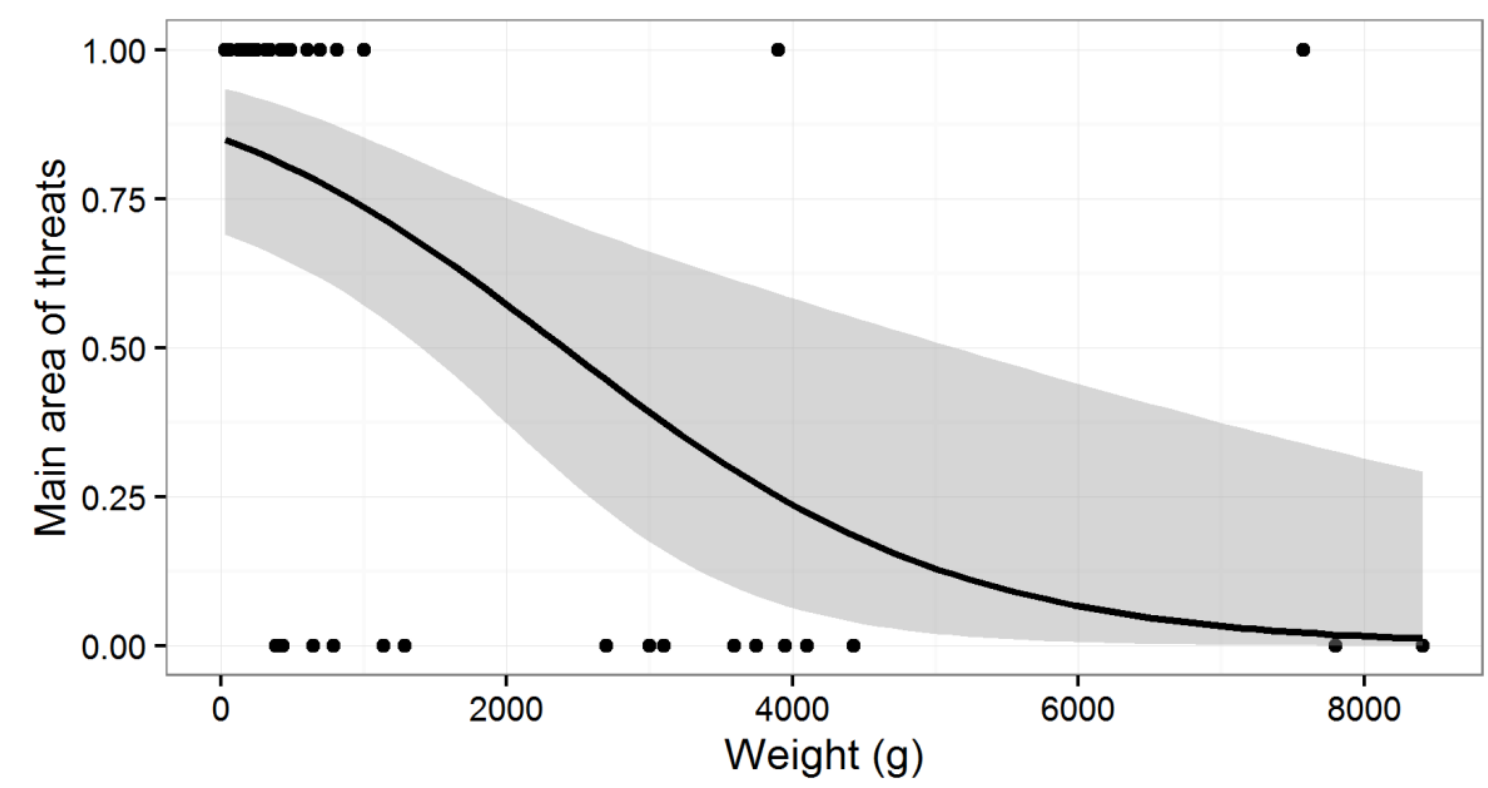

Figure 3. The relationship between the main area of threats $(1=$ onshore, $0=$ offshore) to New Zealand's Procellariiformes compared to the body weight (g) of each species, assessed with a general linear model (GLM) including 95\% confidence intervals.

\section{Conservation actions}

The most common conservation actions undertaken in New Zealand to aid Procellariiformes are bycatch management ( $n=48$ species), population census/ survey $(n=48)$, population dynamics and breeding biology research $(n=46)$, bycatch assessment $(n=44)$ and invasive species control $(n=43)$ (Figure 2). On average, species receive $7.19 \pm 0.22$ different conservation actions, of which $1.63 \pm 0.13$ are onshore, $3.60 \pm 0.15$ are offshore and $1.93 \pm 0.03$ are non-spatial actions (Table 3 ). The number of actions does not differ between Procellariiformes families overall $\left(f_{2,43}\right.$ $=1.803, p=0.177)$, onshore $\left(f_{2,43}=1.094 p=0.344\right)$ or offshore $\left(f_{2,43}=2.788, p=\right.$ 0.070). Endemic species receive attention from more conservation actions than nonendemics overall ( $t=-2.484, d f=42.788, p=0.017)$ and offshore $(t=-2.316, d f=$ $41.718 p=0.026)$, but the amount of actions did not differ onshore $(t=-1.622, d f=$ 39.349, $p=0.113$ ).

Body weight of species is not related to the number of actions overall $\left(R^{2}=\right.$ $0.051, p=0.124)$ or actions onshore $\left(R^{2}<0.001, p=0.952\right)$. However, body weight has a very weak influence on the number of actions offshore $\left(R^{2}=0.099, p=0.030\right)$. 


\section{Conservation correspondence}

Eight conservation action categories were assumed to be directly aimed at a certain threat category. The majority of these actions are corresponding and correlating significantly with their respective threats (Table 4). However, native predator control and translocations are not significantly corresponding and correlating with their respective threats.

Table 4. Correspondence and correlation between threats affecting New Zealand's Procellariiform species and the mitigating conservation actions assessed by Fisher's exact Tests and Spearman correlation tests. Blank indicates $p>0.05$, ${ }^{*}$ indicates $p<$ $0.05,{ }^{* *}$ indicates $p<0.01$ and ${ }^{* * *}$ indicates $p<0.001$.

\begin{tabular}{llrr}
\hline Threat & Conservation action & Fisher's exact test & Spearman's $\boldsymbol{r}$ \\
\hline Invasive species & Invasive species control & $* * *$ & $1.00^{* * *}$ \\
Native predators & Native predator control & $*$ & 0.20 \\
Habitat loss & Habitat management & $*$ & $0.38^{* *}$ \\
Human & Human disturbance & & $0.34^{*}$ \\
disturbance & management & & 0.21 \\
Environmental & Translocations & & \\
stochasticity & & $* *$ & $0.54^{* * *}$ \\
Interspecific & Competition & & \\
competition & management & $* * *$ & $0.77^{* * *}$ \\
Marine pollution & Pollution assessment & & \\
\hline
\end{tabular}


Results from MCA analyses reveal that both onshore and offshore conservation actions are generally applied where these are needed (Figure $4 \& 5$, Table $5 \& 6$ ). The MCA for onshore threats and conservation actions also shows that there is a distance between interspecific competition and competition management, habitat loss and habitat management, and environmental stochasticity. Furthermore, species suffering from climate change, species for which native predator control is in place, and species without population dynamics and breeding biology research, form outliers. The MCA for offshore threats and conservation actions shows a wider spread than the onshore MCA. The offshore MCA also reveals several outlying groups: 1) species that suffer from resource competition, climate change and light pollution, 2) species that are threatened by oil spills and marine pollution and for which pollution assessment is scored, and 3) species that are not threatened by line fisheries, net fisheries and for which population dynamics and breeding biology studies, dietary studies and bycatch assessment are not scored. 

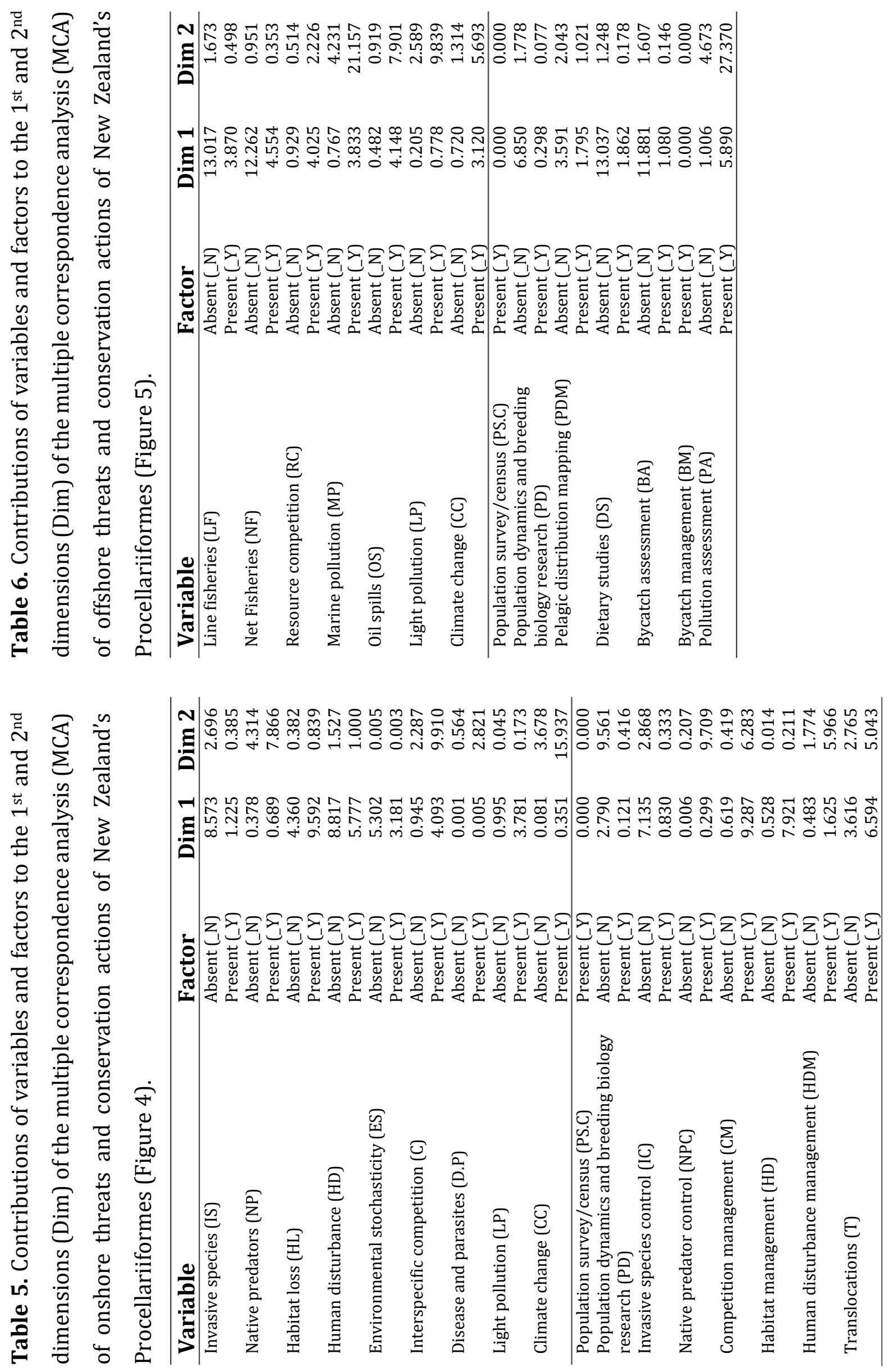


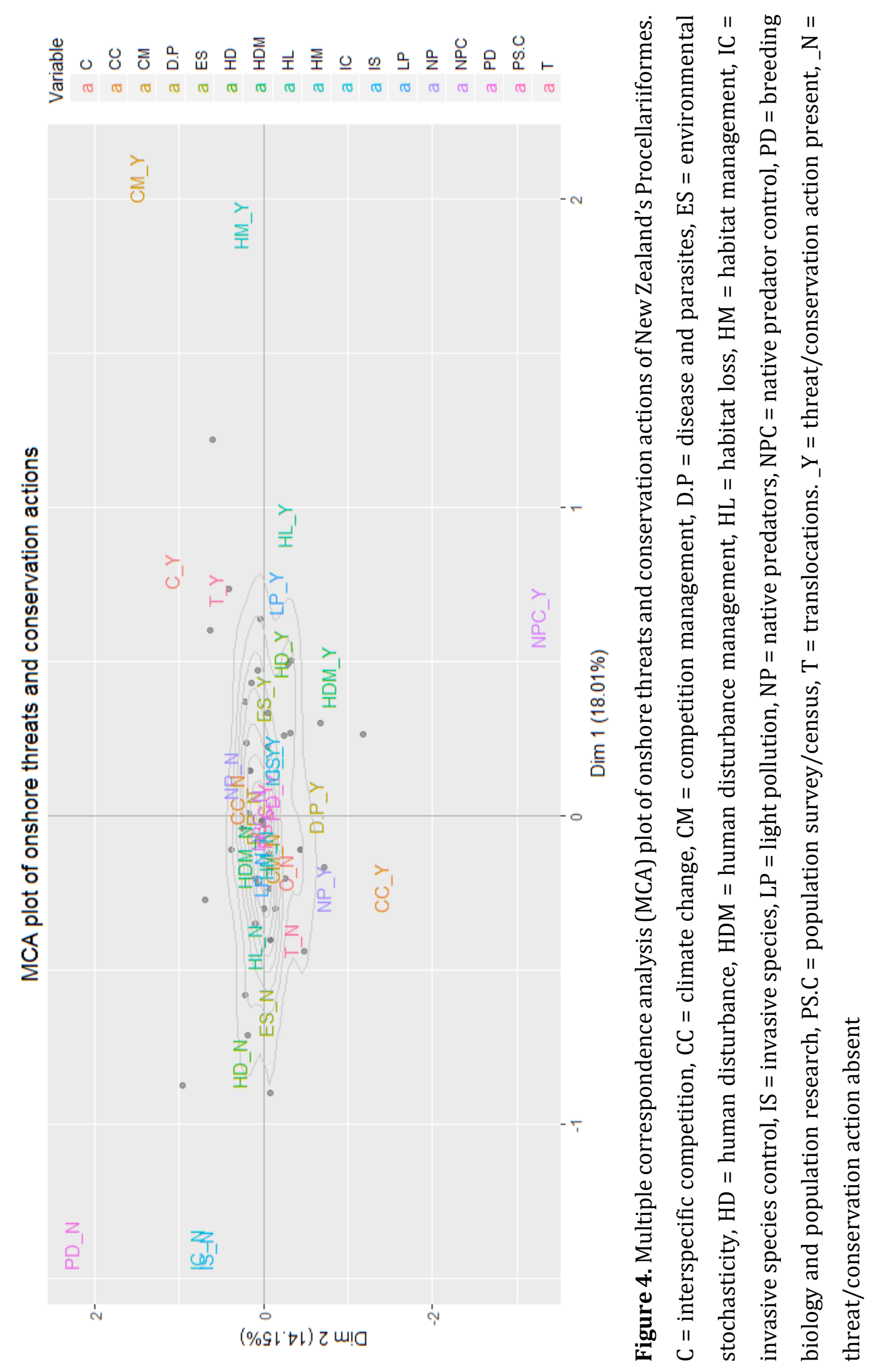




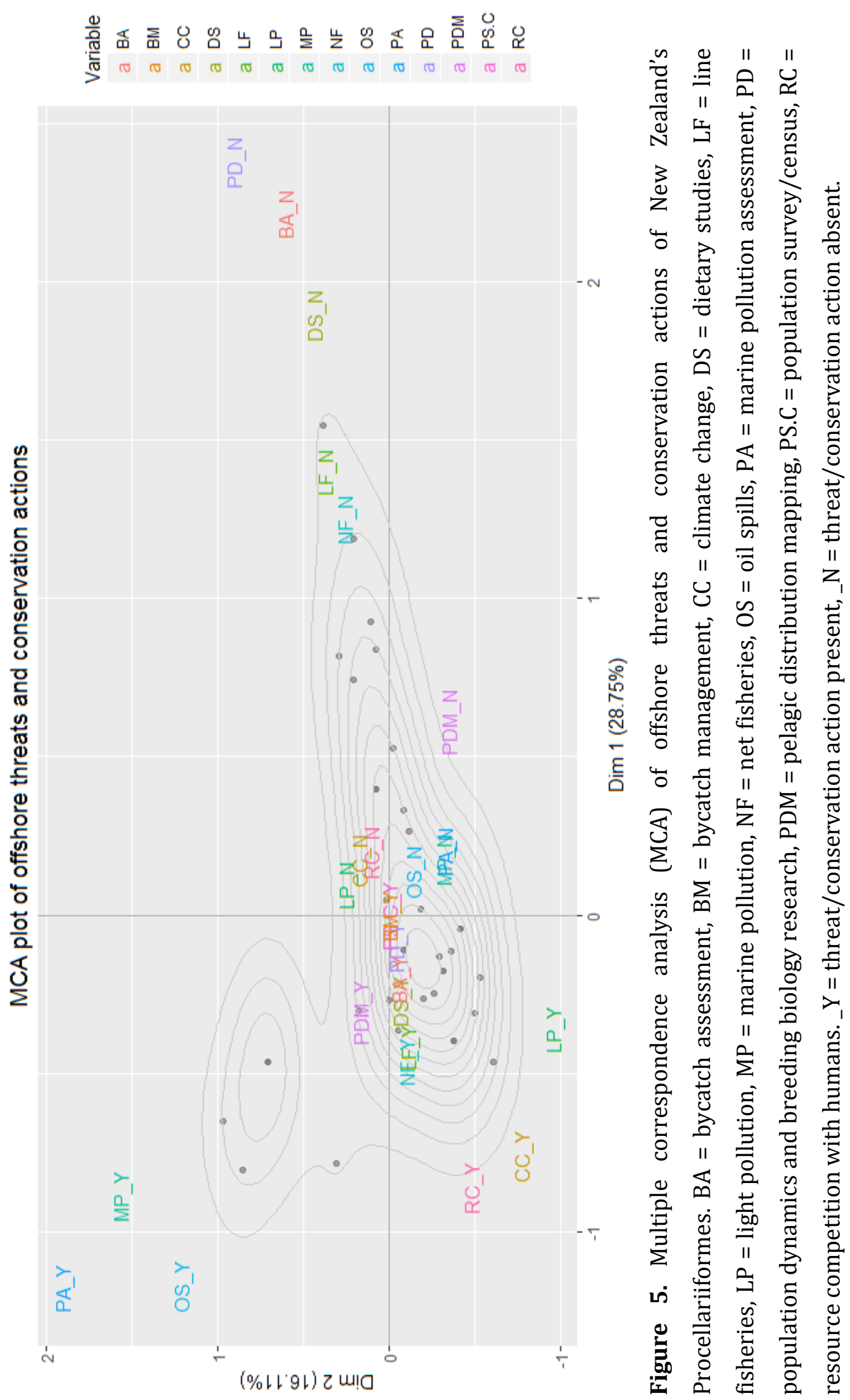




\section{DISCUSSION}

The results of this study show that New Zealand's Procellariiformes are threatened by a range of threats in both terrestrial and pelagic ecosystems. Larger (heavier) species are more threatened by offshore threats, while smaller (lighter) species are mostly threatened by onshore threats. However, body weight has no influence on the amount of threats faced by a species. In addition, a considerable suite of conservation actions is present to mitigate threats. Body weight does not explain the amount of conservation actions per species. In general, these conservation actions appear to be applied where needed, although some gaps exist. Specifically, there appears to be room for improvement to mitigate the risks associated with environmental stochasticity, habitat loss and native predators.

Threats appear spread evenly among New Zealand's Procellariiformes, as neither Procellariiform family, nor endemism, nor body weight influences the number of threats. Procellariiform species are threatened by a larger variety of threats onshore than offshore, but this may be caused by the larger amount of assessed onshore threats than offshore threats.

The shift of main area of threats from terrestrial to pelagic ecosystems with increasing body weight is most likely explained by a lower sensitivity to invasive predators by larger (heavier) Procellariiformes (Jones et al. 2007). Larger seabirds such as members of Diomedeidae and Procellaria petrels within Procellariidae are less prone to predation by invasive species, but suffer significantly from accidental bycatch at sea (Taylor 2000, Abraham \& Thompson 2011).

The demonstrated spread of conservation actions fits international conservation policy. Procellariiform species endemic to New Zealand receive aid from a larger variety of actions than non-endemics, while there is no demonstrated difference between Procellariiform families. New Zealand has the highest number of endemic Procellariiformes (Taylor 2000, Croxall et al. 2012) and endemism is seen as an important factor for prioritisation assessments (Myers et al. 2000). Therefore, when considering the variety of actions as a proxy for conservation focus, the increased focus on endemics fits well within global conservation prioritisation.

The lack of influence of body weight on the number of conservation actions may be indicative of actions being applied were necessary. In general, larger (and thus 
heavier) species are considered more charismatic (Entwistle \& Dusntone 2000). Such species are often used as flagship-species, with the reasoning that if these species benefit from conservation management, other, less charismatic species may benefit too. In this meta-analysis of New Zealand's Procellariiforms, however, the flag-ship species conservation approach does not become evident when considering the spread of actions as a proxy for conservation focus. This suggests that management is applied to aid species were required.

While most conservation actions appear in place where required, certain conservation actions appear in need of improvement. This meta-analysis revealed a lack of correspondence between species suffering from native predators and native predator management. This limited correspondence may be explained by the controversy surrounding native predator management. The absence of correspondence and correlation between environmental stochasticity and translocations may be caused by the limitations of the assumption that this conservation action is directly aimed at this threat. Alternatively, more Procellariiform species in New Zealand are in need of translocations to mitigate the threats associated with stochastic events. The application of habitat management to species threatened by habitat loss also appears in need of improvement. This may indicate a limited focus within New Zealand on habitat loss as a threat to Procellariiformes, yet New Zealand has undergone a substantial reduction in native vegetation (Cieraad et al. 2015). On the other hand, a lack of literature discussing habitat loss as a threat to Procellariiform species in New Zealand might explain the distance in the MCA between species suffering from habitat loss and mitigating habitat management.

Publication bias may have been a factor while researching and compiling literature on the threats and conservation actions directed at New Zealand's Procellariiformes. This is a commonly encountered issue with meta-analyses (Rothstein et al. 2006, Fernandez-Duque \& Vallegia 2010). The publication bias of this part of the study is likely to be smaller for conservation actions than for threats, as conservation actions in New Zealand appear well-documented, even if the results have not been published in peer-reviewed journals (e.g., through DOC reports). Some threats such as invasive species, net- and line fisheries seem thoroughly represented in the literature (e.g., Gaze 2000, Abraham \& Thompson 2011, Abraham et al. 2013, 
Buxton et al. 2015). Other threats may be underrepresented in studies originating from New Zealand. For example, in Hawaii, considerable attention has been directed towards the impact of marine contaminants and plastic debris (Fry et al. 1987, Chu et al. 2015). In comparison, the literature on New Zealand based research addressing this threat appears only marginal (Buxton et al. 2013, Wilcox et al. 2015). A similar pattern may be present for light pollution affecting New Zealand's Procellariiform species, even though this threat is thoroughly documented from Macaronesia and the Mediterranean region (Rodrigues et al. 2012, Rodriguez et al. 2015). In addition, threats such as resource competition with humans and climate change are likely to be underrepresented in the literature, due to the potential difficulties of identifying these threats as direct or indirect causes of population declines.

Considering the range of threats and conservation actions of New Zealand's Procellariiformes, only few fall under the small population paradigm (Caughley 1994). Caughley (1994) proposed two defining paradigms to be present within conservation science: 1) the small population paradigm, and 2) the declining population paradigm. The first paradigm is concerned with the consequences of the smallness and rareness of a threatened population (e.g., inbreeding and stochasticity). The second paradigm is concerned with understanding the causes of the population declines and mitigating these (e.g., invasive species and habitat loss). Seabirds face a considerable suite of different threats that are included in the declining population paradigm and the majority of the assessed threat categories fall under this paradigm. The same pattern appears to hold for the conservation actions addressed in this metaanalysis. Environmental stochasticity affects most assessed species and this is the only assessed threat that falls under the small population paradigm. The only conservation actions that may be applicable to this paradigm is research directed at population dynamics and breeding biology research and translocations. The apparent lack of the small population paradigm in New Zealand's Procellariiformes may illustrate a limited appreciation in New Zealand for this paradigm. On the other hand, genetic threats to seabirds, such as inbreeding, appear surprisingly low, as these highly philopatric birds have been shown to actively choose to mate with close relatives (Cohen \& Dearborn 2004) and breed in extreme proximity of their natal grounds (Steiner \& Gaston 2005), perhaps to avoid outbreeding effects. Therefore, the 
small population paradigm might not be as pressing to Procellariiform species as the declining population paradigm.

\section{CONCLUSION}

Based on the results from this qualitative meta-analysis, I show the variety of threats faced by New Zealand's Procellariiformes and the considerable number of conservation actions in place to address these threats. While certain gaps are present, the majority of conservation actions appear to be aimed directly at the relevant threats present. Conservation of New Zealand's Procellariiformes appears wellstructured overall, which is impressive, given the comparatively limited focus on and commitment to Procellariiformes conservation within New Zealand (Moller et al. 2000). Yet the assessment presented here should be seen as only the first step to improving conservation management. A quantitative assessment using seabird- or Procellariiformes-specific population models will provide much more detailed understanding of the impact of various threats faced by these species and the effectiveness of the mitigating actions. Due to the considerable lifespan and low fecundity ( $K$-strategy) of Procellariiformes (Taylor 2000, Satterthwaite \& Mangel 2012), a quantitative assessment will present considerable challenges, especially given the diversity of New Zealand's Procellariiformes (Moller et al. 2000, Croxall et al. 2012). While detailed data on population dynamics is present for a variety of threats and a limited suit of conservation actions (e.g., Fraser et al. 2011, Waugh et al. 2015), further long-term research is needed to improve understanding of future conservation challenges and directions. As Paleczny et al. (2015) showed that only $3 \%$ of seabird populations in New Zealand and surrounding waters have been monitored regularly, increasing monitoring efforts seems paramount to enable quantitative assessment of population dynamics and thus the magnitude of threats and success of conservation actions. Given the wide-ranging effects of Procellariiformes on their surrounding environment (Furness \& Camphuysen 1997, Paleczny et al. 2015) and the importance of New Zealand for this order (Taylor 2000), continuing and improving current conservation management in New Zealand appears of global conservation interest. 
Chapter 3 


\section{Chapter 3.}

\section{NEST-SITE SELECTION OF SOUTH GEORGIAN DIVING PETRELS ON \\ CODFISH ISLAND, NEW ZEALAND: IMPLICATIONS FOR \\ CONSERVATION MANAGEMENT}

\section{ABSTRACT}

$\mathrm{S}$ MALL SEABIRD SPECIES are often threatened by predation from invasive species at their breeding colonies and considerable effort is invested into mitigating this threat. However, invasive predators may not be the only onshore threat affecting small seabird species. The South Georgian Diving Petrel (Pelecanoides georgicus; SGDP) is a small Procellariiform seabird species, considered Nationally Critical in New Zealand. My objective was to identify the terrestrial threats to the species at their sole remaining breeding colony in New Zealand on Codfish Island (Whenua Hou) following the successful eradication of invasive predators. To achieve my objective, I assessed the influence of five physical, three competition, and three plant variables on the nestsite selection of the SGDP with generalised linear models (GLMs) and compared models using an information theoretic approach. Models including the distance to the sea, slope, aspect and sand flux outperformed other models, and show selection for steep seaward-facing foredunes with mobile soils. In addition, no invasive plant- and competition variables were included in the best performing models, indicating that SGDPs neither avoid invasive vegetation, nor the vicinity of conspecifics, nor the vicinity of other seabird species. These results suggest that SGDPs are extremely vulnerable to effects caused by stochastic events and catastrophes, such as storms and storm surges. Eradication efforts directed at invasive predators on Codfish Island appear thus insufficient to safeguard the SGDP colony necessitating further conservation strategies to ensure the continued survival of this population. 
Chapter 3

\section{INTRODUCTION}

Seabird populations, considered good indicators of ecosystem health (Furness \& Camphuysen 1997), have declined by 70\% over the last 60 years (Paleczny et al. 2015). This is a concern, given that seabirds provide many important ecosystem services including nutrient cycling between pelagic and terrestrial ecosystems (Sekercioglu et al. 2004, Pelaczny et al. 2015, Chapter 2). Seabirds face threats on two fronts: at sea (e.g., accidental by-catch) and at their onshore breeding colonies (e.g., predation by invasive species) (Jones et al. 2007, Abraham \& Thompson 2011). Smaller species are often more threatened onshore, while larger seabird species are more threatened at sea (Jones et al. 2007, Chapter 2).

New Zealand and its numerous offshore islands hosts one of the most diverse seabird communities and the highest number of endemic species globally (Taylor 2000). Local population trends mirror those found globally and as a consequence, New Zealand also has the most threatened seabird community in the world (Croxall et al. 2012) making their conservation of global importance.

New Zealand is considered a world leader in mitigating the negative effects of invasive predators on seabirds (Jones et al. 2016). Numerous eradication programmes have been implemented to control invasive species and protect seabird populations (Towns \& Broom 2003). With increasingly better eradication techniques and protocols, larger islands have been successfully freed of their invasive predators (Towns \& Broome 2003). Several seabird species have benefitted from these eradications (Ismar et al. 2014, Buxton et al. 2015), though the lack of sufficient posteradication monitoring of seabirds is concerning (Jones et al. 2016).

Despite the efforts aimed at the mitigation and eradication of invasive predators, other terrestrial factors, such as habitat loss, may also contribute to population declines or limit population recovery of seabirds (Taylor 2000, Chapter 2). However, these threats seem to receive less attention (Chapter 2). For example, studies directed at investigating exact habitat requirements of seabird species in New Zealand appear rare. Such studies should be encouraged, as habitat selection is one of the key components of ecological research and fundamental to understanding ecological processes (Johnson 1980, Manly et al. 2002). Understanding the mechanisms dictating how and why species choose specific habitats will enhance the 
development of successful management strategies to preserve (seabird) species (Manly et al. 2002, Cassini 2013).

This conundrum is illustrated by the South Georgian Diving Petrel (Pelecanoides georgicus; SGDP) in New Zealand. The SGDP is a small burrow-breeding, Procellariiform seabird with a circumpolar distribution across the southern oceans. Due to its widespread distribution, the SGDP is globally considered Least Concern by the IUCN (2016). In New Zealand, however, the SGDP has declined steeply and was subsequently extirpated across most of its historic range (Worthy 1998, Taylor 2000, Holdaway et al. 2003, Wood \& Briden 2008) (Figure 1). The only remaining SGDP colony in New Zealand currently persists in the dunes of the Sealers Bay on Codfish Island (Whenua Hou). The total SGDP population size on Codfish Island was estimated at 150 adults (Taylor 2013). Therefore, the species is currently considered Nationally Critical by the New Zealand Department of Conservation (DOC) (Robertson et al. 2013).

Underlying causes of decline of the SGDP in New Zealand remain speculative but predation by introduced species, such as Pacific rats (Rattus exulans), was likely a key contributor. However, while the removal of introduced predators (brush-tailed possums (Trichosurus vulpecula), Pacific rats, and Weka (Gallirallus australis)) from Codfish Island (Middleton 2007) initially resulted in an increased population trend of SGDPs between the 1980's and the late 1990's (Imber \& Nilsson 1980, West \& Imber 1989, Taylor 2000), this increase appears to have halted since 2000 (Taylor 2013). The reason for the lack of population growth is unknown, but several contributing factors have been hypothesised. For example, given that SGDPs in New Zealand nest in coastal dunes, the impact of encroachment of the dunes by (invasive) vegetation is currently perceived as a threat (Taylor 2013), even after the successful eradication of Marram Grass (Ammophila arenaria) and Mouse-eared Hawkweed (Pillosella officinarum) (Wickes \& Rance 2010, Taylor 2013, DOC unpub. data). Due to the potential preference of SGDPs for coastal dunes for nesting, stochastic events and catastrophes such as storms might pose additional risks (Cole 2004). Furthermore, as Common Diving Petrels (P. urinatrix; CDP) recently have started breeding in the same dunes (Taylor \& Cole 2002) competition for nest-sites might also pose a threat to the SGDP. No pelagic threats have yet been identified for the Codfish Island population 
(Taylor 2000), though collision with vessels caused by anthropogenic light pollution has been recorded for other populations (Black 2005).

To better understand potential onshore threats to the SGDP on Codfish Island, I conducted burrow searches and recorded a range of physical and biological variables at both burrows and random points between November 2015 and February 2016. I aimed to identify the most important dune characteristics influencing nest-site selection in SGDPs. Such information is essential to assess threats and identify conservation management options for the SGDP in New Zealand.

\section{METHODS}

\section{Study area}

I collected data on the nest-site selection of SGDPs in the Sealers Bay dunes (-46.766, 167.645) on Codfish Island (Whenua Hou), approx. $3 \mathrm{~km}$ west of Stewart Island (Figure 1). I defined the exact study area using an aerial photograph of Codfish Island (G. Elliott unpub. data 2004) geo-referenced to NZGD2000. The borders of the study area were defined by the Sealers Bay beach in the north, the forests of Codfish Island in the south and east, and an unnamed stream in the west. The size of this area was approx. $100 \times 900 \mathrm{~m}$, encompassing the entire Sealers Bay dunes and all SGDP burrows identified in previous surveys (Taylor \& Cole 2002, Cole 2004).

\section{Habitat selection}

I assessed habitat selection within a use versus availability framework at the fourth scale of habitat selection (the selection of resources for one specific type of behaviour; Johnson 1980), i.e. nest-site selection. I considered SGDP burrows as used sites. To account for the available habitat, I created 150 random points within the entire study area using a random point generator in ArcGIS 10. At the study site, I marked random points with a bamboo/fibreglass pole and a track marker with an ID number. I discarded 19 random points, because they were located below the spring tide line.

As previous surveys (Imber \& Nilsson 1980, Taylor \& Cole 2002, Cole 2004) indicated a strong dependency on foredunes, I assessed habitat selection using two approaches: 1) habitat selection in the whole dune system, and 2) habitat selection in the foredune system. For the first approach, I included data from all random points (n 
$=131$ ) in the analyses. For the second approach I created a $20 \mathrm{~m}$ buffer around each detected burrow site in ArcGIS 10 and discarded all random points falling outside this buffer. The total number of remaining random points within these $20 \mathrm{~m}$ buffers was $\mathrm{n}=45$.

\section{Burrow searches and occupancy assessment}

I searched for burrows of Diving Petrels (Pelecanoides ssp.) and other Procellariiformes in the study area for ten days in November 2015. Burrow searches were made by walking the length of the dunes in pairs with $10 \mathrm{~m}$ distance between observers. I marked every detected burrow with a bamboo/fibreglass pole, a track marker with an ID number and a reflector (to enable safe navigation of the colony at night and minimize impact on breeding birds). In addition, I took a GPS point for each burrow.

I used various techniques to determine burrow occupancy. In November and December 2015, I monitored the burrows with stick palisades (Johnston et al. 2003) and checked these palisades twice per week. I considered burrows with more than three records of knocked over sticks as occupied to account for false positives (Taylor et al. 2012). To identify the species present in the burrows I used playback of calls of both SGDPs and CDPs in combination with hand capture of birds at night (Taylor \& Cole 2002). In January 2016, I used burrow traps custom-made for Pelecanoides ssp. (length $=20 \mathrm{~cm}, \varnothing=8 \mathrm{~cm}$ ) at night to identify the occupants of remaining unidentified active burrows. Traps were checked every 45 to 60 minutes to prevent (heat) stress in these birds.

\section{Variables affecting nest-site selection}

I recorded a range of physical and biological variables at both burrows and random points. I identified plant species within a circle with $1 \mathrm{~m}^{2}$ surface area, using Wilson (2009) and Wickes \& Rance (2010) as references. I estimated the cover of each plant species as the vertical projection of all foliage onto a horizontal surface within this 1 $\mathrm{m}^{2}$ circle. To reduce the number of explanatory variables, I summed the cover of all recorded plant species to form the variable plant cover. I also assessed the effect of invasive plant species such as Cock's Foot (Dactylus glomerata), Yorkshire Fog (Holcus lanatus), and Catsear (Hypochaeris radicata). To further reduce the number 
of explanatory variables, I summed the cover of all invasive plant species which I then divided through the sum of the cover of all plant species to form the explanatory variable invasive plant ratio. Due to the high vegetation density at some sites, I refrained from measuring maximum standing vegetation height and instead classified plant height into one of five classes $(0.0-0.5 \mathrm{~m}, 0.5-1.0 \mathrm{~m}, 1.0-1.5 \mathrm{~m}, 1.5-2.0$ $\mathrm{m}$, and $>2.0 \mathrm{~m}$ ). I measured slope with a handheld clinometer. I measured aspect using a handheld compass and transformed recorded values to values between 2 and 0 using the Beers et al. (1966) transformation. The maximum aspect in this transformation was considered $45^{\circ}$, because the Sealers Bay dunes are a northeast facing dune system. I assessed soil compaction using a hand-held penetrometer (AMS Inc. G-281) with an adapter foot (AMS Inc. G-282) for sensitive soils (Ø 2.54 $\mathrm{cm})$. With this penetrometer I measured the force needed to penetrate the soil to a depth of $6.4 \mathrm{~mm}$ in $\mathrm{kg} / \mathrm{cm}^{2}$. To account for micro scale variation I measured the soil compaction five times within a $1 \mathrm{~m}^{2}$ circle at each site (at the centre and on the edge in each wind direction) and averaged values per site. I investigated sand flux by measuring the accumulation or erosion of sand at the poles marking the sites over the course of two months (49-66 days). I accounted for the difference in exposure time between sites by dividing sand flux ( $\mathrm{mm}$ ) through the number of days. I measured the distance to the sea, defined by the spring-tide line, the distance to the closest occupied SGDP burrow and the distance to other seabird species burrow in $\mathrm{m}$ in ArcGIS 10.

\section{Data analysis}

I constructed a priori models aligning with several biologically plausible hypotheses. I only included explanatory variables with Spearman correlation coefficients of $r \leq$ 0.6 in the same model. I then used generalised linear models (GLM) with a logit-link function to analyse nest-site selection of the SGDP. I applied the Akaike Information Criterion corrected for small sample sizes (AIC)) (Burnham \& Anderson 2002) to identify the relative importance of variables affecting nest-site selection by SGDPs. I also generated a "full" model (a model that includes all uncorrelated variables with the highest indicative fit) and a null model. For each model, I generated the AIC difference in $\mathrm{AIC}_{\mathrm{C}}$ values relative to the best model $\left(\triangle \mathrm{AIC}_{\mathrm{C}}\right)$ and Akaike weights $\left(w_{\mathrm{i}}\right)$. I considered models with a $\Delta \mathrm{AIC}_{\mathrm{C}}<4.0$ to be supported by the data (Burnham $\&$ 
Anderson 2002). I summed the $w_{\text {i }}$ from all supported models to assess the relative importance of each variable (RVI).

The analysis of SGDP nest-site selection was then repeated, as explained above, for the $20 \mathrm{~m}$ buffer created around each burrow with the remaining dataset. However, I also accounted for biologically plausible interactions between explanatory variables in this second layer of analysis, as biotic variables in foredune habitats are under considerable pressure from abiotic influences (Hesp 1999).

All statistical analyses were conducted in Program R (R Development Core Team 2016) using the Hmisc (Harrel 2016) and MuMIn (Bartoń 2015) packages. I used the ggplot2 package (Wickham 2009) for visual interpretation, with Locally Estimated Scatterplot Smoothers (LOESS), of the most important variables affecting SGDP nest-site selection. 
Chapter 3

\section{RESULTS}

\section{Burrow searches and occupancy}

In total, 143 Pelecanoides ssp. burrows were found in the study area, of which 109 showed signs of occupancy. Using playback, hand captures and burrow traps 74 SGDP burrows, six CDP burrows and four burrows with mixed occupancy (one burrow was inhabited by a SGDP x CDP pair, two SGDP burrows were taken over by CDPs and one CDP burrow was taken over by SGDPs) were identified. The occupants of 25 Pelecanoides ssp. burrows remained unidentified. In addition, seven larger burrows were found inhabited by Sooty Shearwaters (Puffinus griseus).

\section{Relative importance of variables in the whole dune system}

Distance to sea was highly correlated $(r \geq 0.6)$ with distance to nearest conspecific, plant cover and plant height (Appendix 4). Distance to nearest conspecific was also highly correlated with plant cover and plant height. In addition, plant cover was highly correlated with plant height. Therefore, these dune variables were not included in the same models.

Distance to sea, slope, aspect, sand flux and penetration were all explanatory variables present in the best performing models ( $\mathrm{AIC}_{\mathrm{C}}<4.0$; Table 7). Distance to sea, slope and aspect were the most important variables for SGDP nest-site selection (RVI $=0.961$; Table 8), followed by sand flux $(\mathrm{RVI}=0.861)$ and sand penetration $(\mathrm{RVI}=$ 0.381). The relationship between SGDP nest-site selection and the distance to the sea was negative (Table 8 and Figure 6). The relationship between SGDP nest-site selection and slope, aspect and sand flux was positive, while the relationship with sand penetrability was negative. SGDP thus selected for dunes within $20 \mathrm{~m}$ distance from the sea (foredunes) with steep, northeast (seaward) facing slopes, high sand flux and, loose soils. Competition and plant parameters were not included in the best models. 


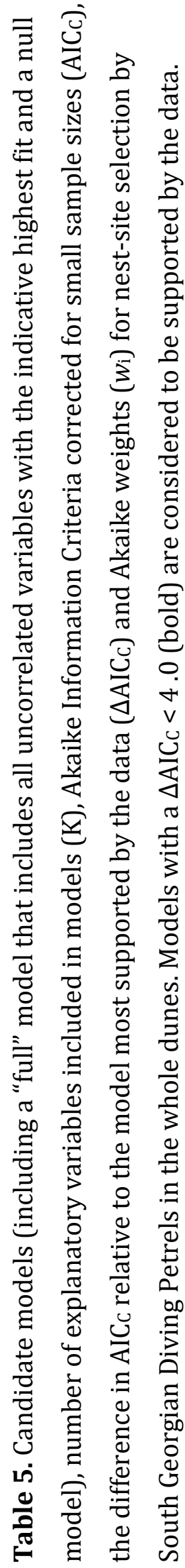

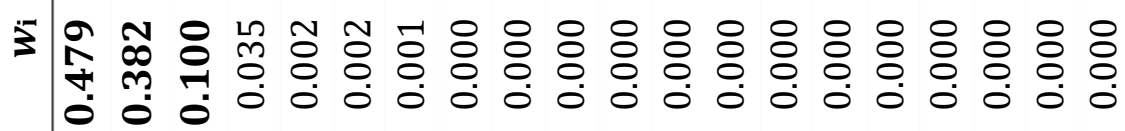

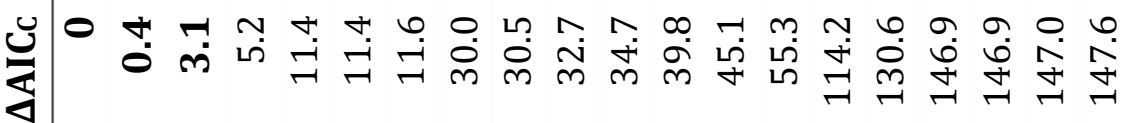
U N $N$ N $N$ N

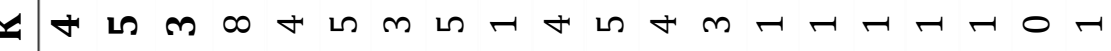
(3) है 严

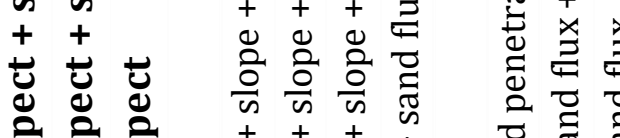
के के के

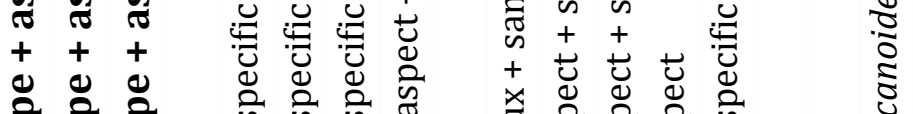

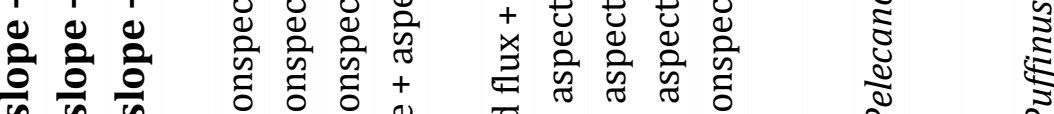

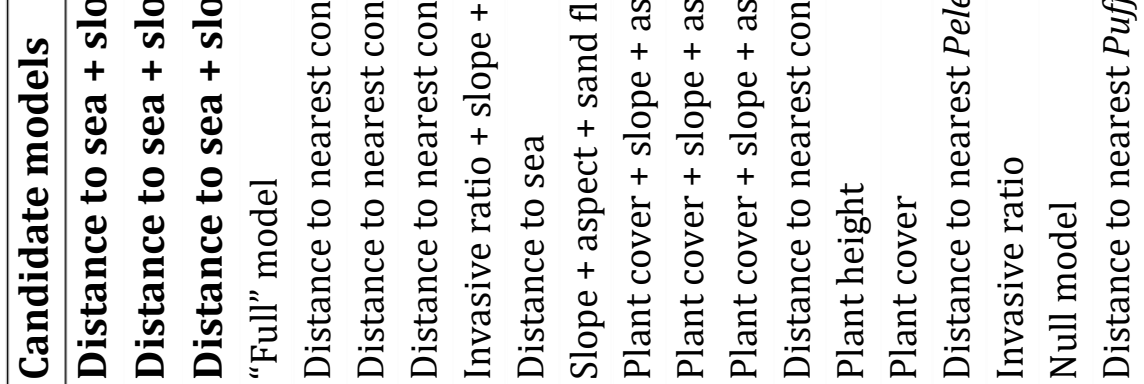



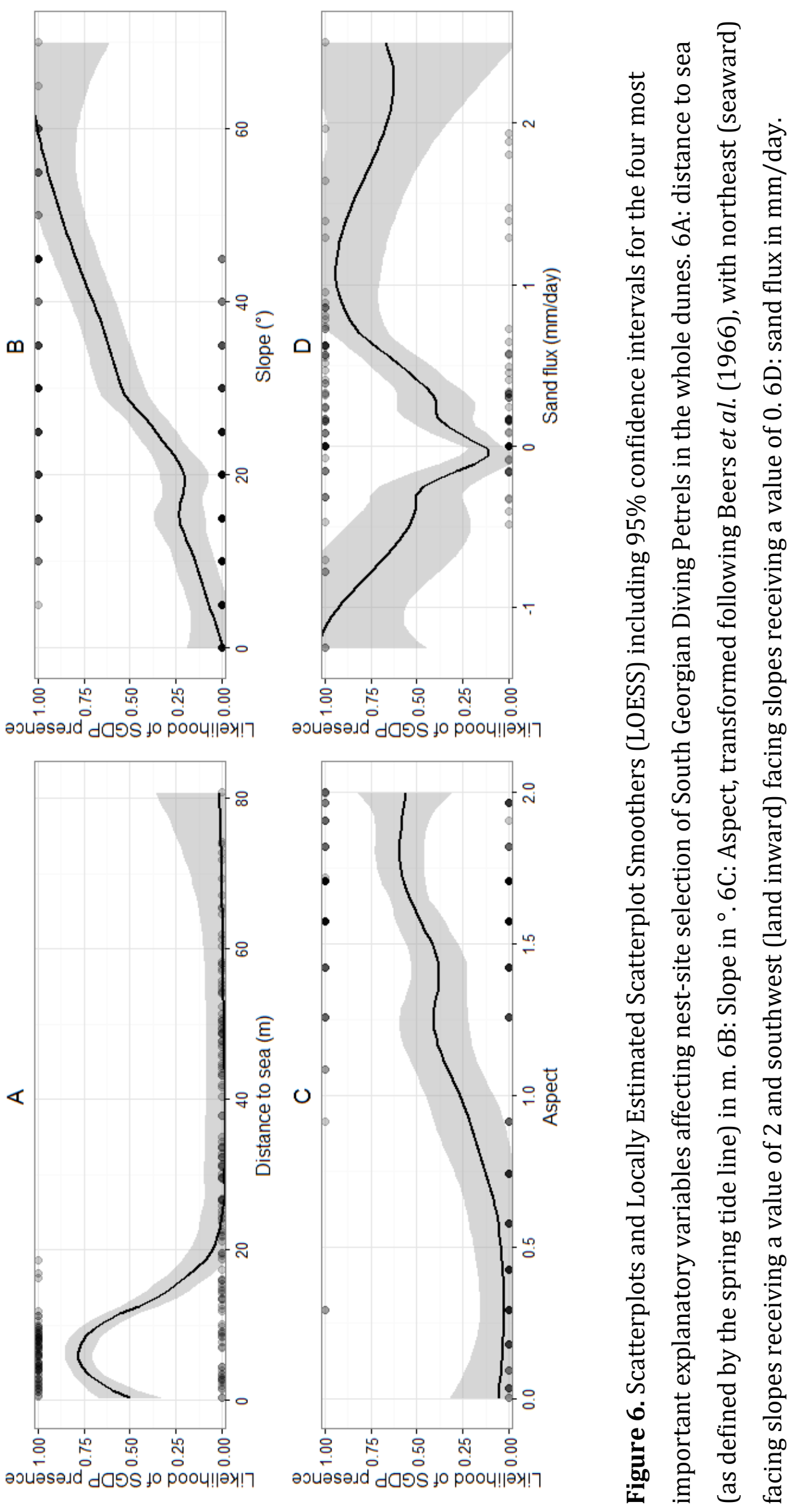
Table 6. Regression coefficients $(\beta)$, standard errors (SE) and relative variable importance (RVI) for explanatory variables included in the best preforming nest-site selection models for South Georgian Diving Petrels in the whole dunes ( $\mathrm{AIC}_{\mathrm{C}}<4.0$ ). * indicates that $\beta \pm 2 *$ SE does not intersect 0 .

\begin{tabular}{lrrr}
\hline Variable & $\boldsymbol{\beta}$ & SE & RVI \\
\hline Distance to sea & $-0.188^{*}$ & 0.033 & 0.961 \\
Slope & $0.105^{*}$ & 0.016 & 0.961 \\
Aspect & $2.090^{*}$ & 0.411 & 0.961 \\
Sand Flux & $0.759^{*}$ & 0.315 & 0.861 \\
Sand penetrability & $-23.950^{*}$ & 3.987 & 0.381 \\
\hline
\end{tabular}

\section{Relative importance of variables in the foredune}

No explanatory variables were highly correlated in the foredune (Appendix 5). In the foredune, distance to sea, slope, aspect, sand flux and plant cover were explanatory variables present in best performing models (Table 9). Distance to sea, slope, aspect, and plant cover were important factors for SGDP nest-site selection (RVI = 0.843). Sand flux appeared less important in the foredune (RVI $=0.317$ ). There was a positive relationship between SGDP nest-site selection and slope and aspect, while there was a negative relationship with the distance to the sea (Table 10). Within the foredune, SGDPs thus also selected for dunes close to the sea with steep seaward-facing slopes. Furthermore, the interactions between the distance to sea and physical dune variables proved influential as well as the interactions between plant cover and the physical dune variables (Table 10 and Figure 7). Within the foredune no competition variables were included in the best performing models and neither were invasive plant ratio and plant height. 


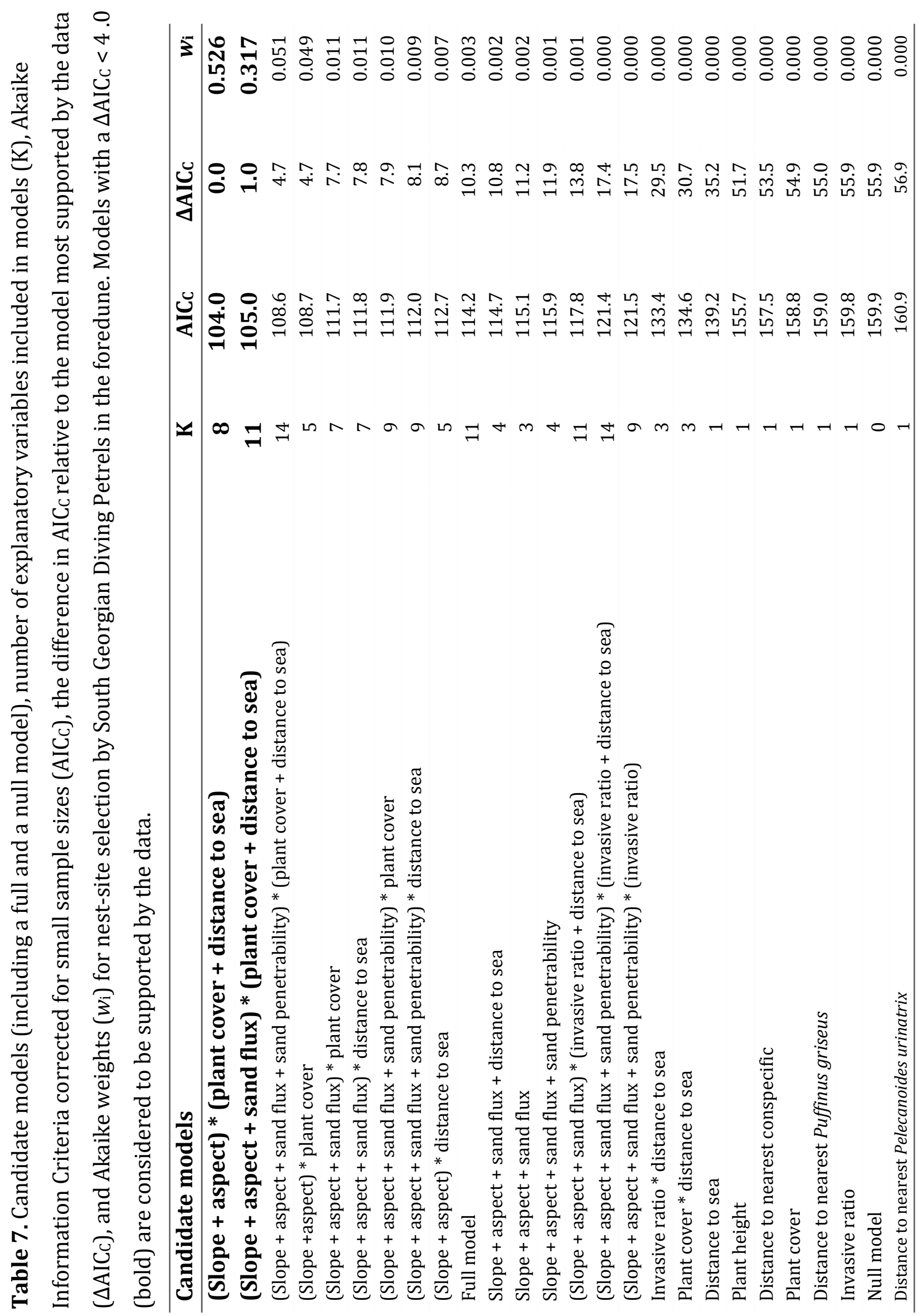


Table 8. Regression coefficients $(\beta)$, standard errors (SE) and relative variable importance (RVI) for explanatory variables included in the best preforming nest-site selection models for South Georgian Diving Petrels in the foredune ( $\mathrm{AIC}_{\mathrm{C}}<4.0$ ). * indicates that $\beta \pm 2 *$ SE does not intersect 0 .

\begin{tabular}{lrrr}
\hline Variable & $\boldsymbol{\beta}$ & SE & RVI \\
\hline Slope & $0.090^{*}$ & 0.019 & 0.843 \\
Aspect & $2.052^{*}$ & 0.531 & 0.843 \\
Plant cover & 0.976 & 0.672 & 0.843 \\
Plant cover : slope & 0.053 & 0.070 & 0.843 \\
Plant cover : aspect & $4.061^{*}$ & 1.928 & 0.843 \\
Distance to sea & $-0.162^{*}$ & 0.039 & 0.843 \\
Distance to sea : slope & 0.006 & 0.004 & 0.843 \\
Distance to sea : aspect & 0.205 & 0.133 & 0.843 \\
Sand Flux & -0.114 & 0.320 & 0.317 \\
Plant cover : sand flux & 0.558 & 1.120 & 0.317 \\
Distance to sea : sand flux & 0.071 & 0.067 & 0.317 \\
\hline
\end{tabular}




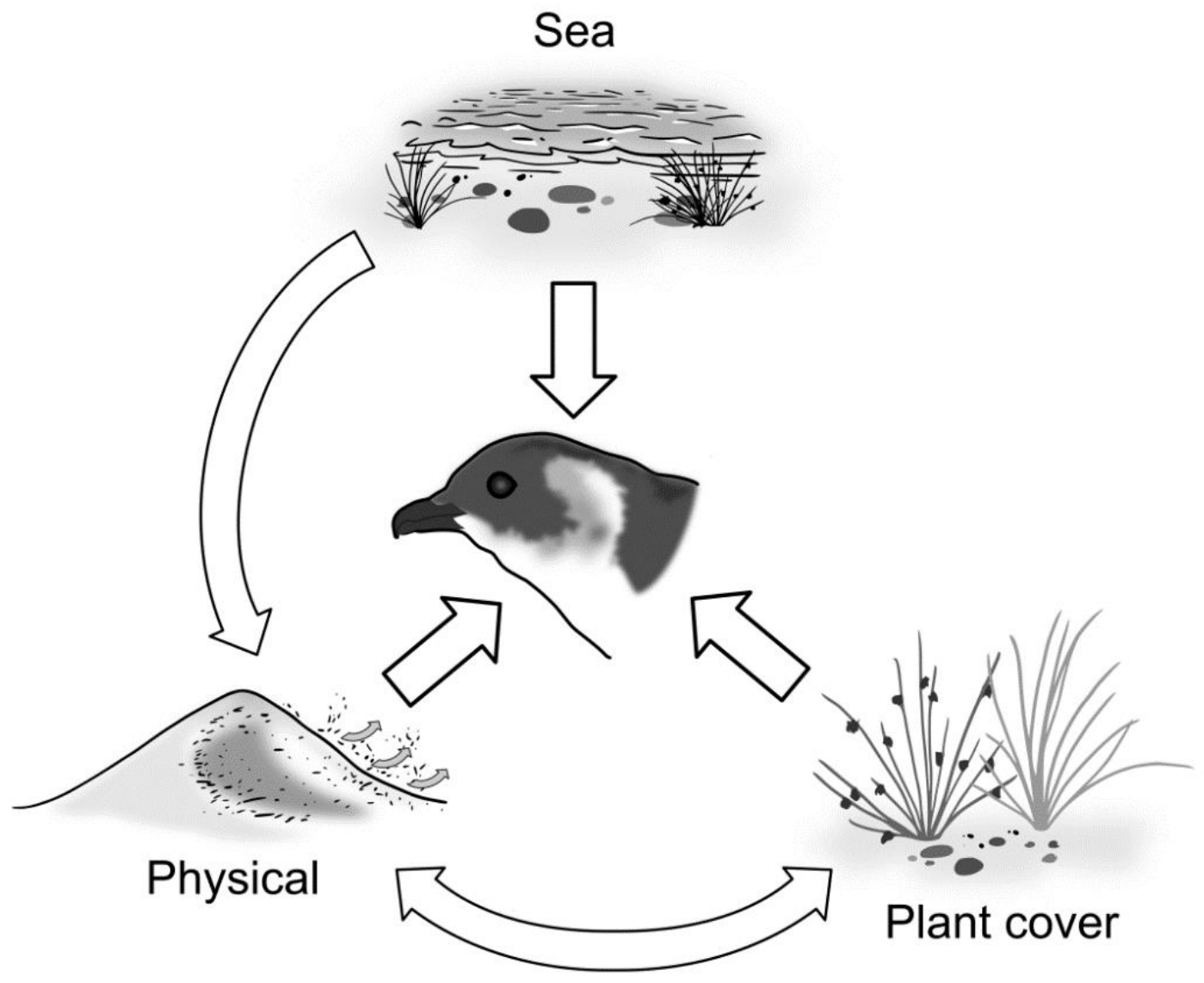

Figure 7. Explanatory variables and interactions affecting nest-site selection in South Georgian Diving Petrels in the foredunes. "Physical" consists of a cluster of slope, aspect and sand flux.

\section{DISCUSSION}

My results show that SGDP nest-site selection is dictated by the distance to the sea, physical dune variables (slope, aspect, sand flux and, to some extent, sand penetrability) and plant cover. SGDPs select for foredunes with steep seaward facing slopes and mobile soils. Interactions between physical variables and the distance to the sea as well as interactions between physical variables and plant cover also affect nest-site selection in SGDPs. Competition or invasive plants do not affect SGDP nestsite selection. 
The strong preference of SGDPs to nest in dunes close to the sea (not further than 20 m inland) is best explained by need for these birds to have a close "runway" for easy departure from the island. SGDPs have relatively short, paddle-like wings adapted to wing-propelled diving (Onley \& Scofield 2007) and may therefore struggle to take off under certain circumstances. On calm nights, I observed that birds ran down onto the Sealers Bay beach and use it as a "runway" in order to take off. Steep seaward-facing dunes provide easy take-off sites and direct access to the sea during windy nights.

The preference for sites with mobile and loose soils might be caused by an inclination of SGDPs to construct nests in soils that allow easy burrowing and are freedraining. The SGDPs breed in relatively deep burrows (up to $2 \mathrm{~m}$ ), which are excavated by the birds. It should be noted that my assessment of penetrability was limited to the uppermost sand layer. Further assessment of the penetrability of deeper soil layers is likely to provide further insights on the effect of sand penetrability on SGDP nest-site selection.

Biotic and abiotic variables affect each other in dynamic ecosystems such as foredunes. For example, the distance to the sea shapes the physical variables in the foredunes (Hesp 1999). The exact interactions between physical variables and overlaying plants remain poorly understood, as physical dune characteristics will influence plants (e.g., Sykes \& Wilson 1990, French 2012, Murphy et al. 2012), but plants can also shape dune profiles by changing physical variables (Hesp 1999). Therefore, it is not surprising that SGDP nest-site selection is affected by interactions between multiple variables. Further investigations will be necessary to unravel how different variables affect each other and consequently the SGDP nest-site selection.

Given the preference of SGDPs for steep seaward-facing and mobile foredunes, this species is very susceptible to stochastic events and catastrophes such as storms during the breeding season. Storms are already impacting SGDPs on Codfish Island. In 2003 a storm extirpated at least $15 \%$ of the population, destroyed $40 \%$ of the nests and removed the first $10 \mathrm{~m}$ of the dunes (estimated at 23,377 $\mathrm{m}^{3}$ of sand; Cole 2004). Unfortunately, storm events and storm surges are likely to increase in both intensity and severity in New Zealand due to human-induced climate change (Blair 2007, Hennessy et al. 2007). If a similar event were to be repeated, 67 burrows (91\%) might be lost, as they were located within the first $10 \mathrm{~m}$ of dunes above the spring tide line. 
Even under the assumption that, if only the burrow entrance is affected and the burrow might still be successful, 49 burrows (66\%) are still at direct risk of another storm event (as burrows are roughly $2 \mathrm{~m}$ long). Therefore, severe storms and storm surges during the breeding season are likely to be the most detrimental current threat to SGDPs on Codfish Island.

Avoidance of conspecifics and other Procellariiformes species does not appear to prominently factor into nest-site selection of SGDPs. However, as three SGDP nests failed due to interactions with CDPs (including the mixed pair), CDPs do appear to compete with SGDPs for some nest-sites (Chapter 4). Competition for nest-sites with other, more abundant Procellariiformes, is common in New Zealand. For example, the Chatham Petrel (Pterodroma axillaris) was put at extreme risk of extinction by nestsite competition with the aggressive Broad-billed Prion (Pachyptila vittata) (Gardner \& Wilson 1999, Sullivan \& Wilson 2001, Gummer et al. 2015), which vastly outnumbered Chatham Petrels. In the case of possible nest-site competition between the SGDP and the CDP, the threatened species still outnumbers the competing species within the colony. However, CDPs appear to be more aggressive than SGDPs (S. Trainor pers. comm. 2016) and if the number of CDPs within this colony increases, they may well form a significant threat to the SGDPs in the future.

My results showed that SGDP nest-site selection is not influenced by invasive plant species. This may have been due to the recent successful eradication of Marram Grass and Mouse-eared Hawkweed from the Sealers Bay dunes (Wickes \& Rance 2010, Taylor 2013, DOC unpub. data). Localised removal of Marram Grass on the Chatham Islands, New Zealand, has allowed the Endangered Chatham Island Oystercatcher (Haematopus chathamensis) to breed further away from the high tide line (Moore \& Davis 2004, IUCN 2016). This action reduced the impact of storms and storm surges for this species. However, there is no evidence that supports a movement of SGDP burrows further inland since the eradication of Marram Grass on Codfish Island. The only common invasive plant species within the SGDP colony are currently Cock's Foot, Yorkshire Fog, Catsear, and Hawkbit (Leontodon taraxacoides). These species might not be strong sand binders and therefore do not influence physical variables in the dunes. However, the Sealers Bay dunes remain vulnerable to (re)invasion of notorious sand binders, as the (re)discovery of several individuals of the invasive Purple Groundsel (Senecio elegans) within the dunes illustrated. Thus 
continued biosecurity and vegetation monitoring of the dunes should be part of future monitoring efforts.

The results showing SGDP preference for fragile foredunes provide an initial step towards understanding the exact mechanisms of nest-site selection in the SGDP. For example, many Procellariiformes show strong nest-site fidelity (Miskelly et al. 2009). Foredunes are inherently mobile and dynamic (Hesp 1999), therefore it is possible that dune variables dictating nest-site selection may change over time. Given the short-term nature of my study, a continued multi-year monitoring programme of the SGDP population in combination with a study assessing nest-site selection of new burrows is recommended.

\section{CONCLUSION}

Eradication of invasive predators may sometimes be insufficient to aid population recovery of small seabirds. The past eradication efforts on Codfish Island were aiming to facilitate population recovery of several small seabird species (Middleton 2007). However, other terrestrial threats can also be present and may be preventing recovery, as illustrated here by the vulnerability of South Georgian Diving Petrels to stochastic events, caused by their dependency on fragile foredunes. Consequently, continued monitoring after eradication efforts is necessary to identify such threats, and additional conservation measures may be required to ensure population recovery of certain species, including the South Georgian Diving Petrel on Codfish Island. 
Chapter 4 
Chapter 4.

ASSESSING THE SUITABILITY OF NON-INVASIVE METHODS TO

MONITOR INTERSPECIFIC INTERACTIONS AND BREEDING BIOLOGY

OF THE SOUTH GEORGIAN DIVING PETREL

\section{ABSTRACT}

DREDATION BY INVASIVE mammals has devastated New Zealand's seabird populations. However, seabirds also face a variety of other threats including competition for nest-sites (burrows). Furthermore, the habit of breeding in burrows, limits breeding biology studies in many small seabirds. I assessed the potential impact of interspecific interactions on the breeding success of the South Georgian Diving Petrel (Pelecanoides georgicus), a Nationally Critical seabird species in New Zealand, by monitoring 20 burrows with remote cameras and stick palisades. Additionally, I tested the use of remote cameras to non-invasively study the breeding biology and activity patterns of the South Georgian Diving Petrel by pairing five remote cameras with Radio Frequency Identification (RFID) readers. I recorded seven species at SGDP burrows. One species caused two monitored burrows to fail: the Common Diving Petrel (P. urinatrix), which thus may pose a potential threat to the South Georgian Diving Petrel. These results suggest that remote cameras are useful tools to study interspecific interactions at seabird burrows. However, cameras had extremely low detection rates $(\bar{x}=10.86 \% \pm 7.62 \%)$ when compared to RFID readers. The low detection rates of South Georgian Diving Petrel activity at their burrows may be explained by their small body size and the speed at which birds enter and exit burrows. Therefore, remote cameras, or at least the model we used, appear unsuitable to study breeding biology and activity patterns in this, and possibly other small burrowing seabirds. 
Chapter 4

\section{INTRODUCTION}

Seabirds are one of the most threatened taxonomic groups on the planet (Croxall et al. 2012). Due to their life history, seabirds are threatened on two fronts: on land and at sea (Taylor 2000). Invasive mammalian predators, such as rats (Rattus ssp.), are considered one of the most detrimental terrestrial threat to seabirds in general, and smaller species in particular (Jones et al. 2007, Chapter 2). However, substantial effort is being invested into mitigating their impacts through island-wide eradications (Towns \& Broome, Jones et al. 2016). In New Zealand, home to one of the most diverse and threatened seabird communities on the planet, invasive mammalian predators have severely decimated the abundance and distribution of seabird species and populations (Taylor 2000, Croxall et al. 2012).

Besides invasive mammals, the already decimated seabird populations in New Zealand face several other threats on shore, including habitat loss and effects of stochastic events (Taylor 2000, Chapter 2 \& 3). Furthermore, interspecific interactions, other than predation by invasive species, can impact seabird populations (Friesen et al. 2016, Chapter 2). Various cases of negative interactions with native species have been documented, including Morepork (Ninox novaeseelandiae) predation, non-predatory attacks by Campbell Island Teals (Anas nesiotis), and competition between various seabird species for nest-sites (Sullivan \& Wilson 2001, Trainor 2008, Friesen et al. 2016, Sagar et al. 2016). In some instances, such interactions have contributed to extreme population declines (Sullivan \& Wilson 2001).

Many small seabird species in New Zealand breed in burrows, restricting our ability to study breeding biology and activity patterns. To overcome this limitation, several techniques have been used. The simplest method to monitor activity patterns is the use of stick palisades (a row of sticks in front of the burrow entrance), but this method is prone to false positives (Taylor et al. 2012). An approach to study both activity patterns and breeding biology is the instalment of study burrows (the placement of a door into a burrow that allows the access to brood chambers). However, the use of study burrows is labour intensive, invasive and may not always be feasible (Blackmer et al. 2004, Taylor et al. 2012). In more recent years, the development of new technologies has produced less invasive study methods. For 
example, Radio Frequency Identification (RFID) readers, also known as Passive Integrated Transponder (PIT) readers, have been used to study small burrowing seabirds (e.g., Zangmeister et al. 2009, Taylor et al. 2012). RFID readers allow the automated monitoring at burrow entrances of individuals equipped with RFID tags. Additionally, remote cameras are increasingly being used to monitor burrows and assess breeding biology and activity patterns (Taylor et al. 2012, Dilley et al. 2015). However, the use of remote cameras poses considerable challenges, as large amounts of footage need to be viewed and assessed (Johnston et al. 2003). On the other hand, remote cameras provide the opportunity to assess interspecific interactions at burrows (Dilley et al. 2015).

The South Georgian Diving Petrel (Pelecanoides georgicus; SGDP) is a small, burrowing seabird species. The SGDP is considered Nationally Critical in New Zealand (Robertson et al. 2013), because it is limited to Codfish Island (Whenua Hou) (Figure 1) and the population numbers a mere 150 individuals approximately (Taylor 2000). Codfish Island is free of invasive predators following eradication efforts (Middleton 2007). Invasive species are likely to have been the main cause of the historic population declines in this species (Taylor 2000). However, dune erosion, caused by storms, continues to threaten this small SGDP colony (Chapter 3). Furthermore, interactions with other species may also reduce the reproductive success of this species. For example, the SGDP may suffer from competition for nest-sites with the Common Diving Petrel (P. urinatrix; CDP) (Chapter 3). In addition, Morepork predation has been recorded anecdotally (Trainor 2008). Currently available data on the SGDP breeding biology and activity patterns are either anecdotal (Taylor \& Cole 2002, Cole 2004, Trainor 2008, Trainor 2009) or originate from populations from different oceans (Payne \& Prince 1979, Marchant \& Higgins 1990).

To gain a better understanding of interspecific interactions affecting SGDP breeding success on Codfish Island, I monitored 20 occupied SGDP burrows with remote cameras during the presumed chick rearing period (Taylor 2013). In addition, to assess the utility of remote cameras to monitor and study the breeding biology and activity patterns of the SGDP, I paired five remote cameras with RFID readers. 
Chapter 4

\section{METHODS}

\section{Study area}

The SGDP in New Zealand is limited to one colony at the Sealers bay dunes $(-46.766$, 167.645) on Codfish Island, approx. $3 \mathrm{~km}$ west of Stewart Island (Figure 1). I defined the exact study area using aerial photographs (G. Elliott unpub. data 2004) georeferenced to NZGD2000 and maps of previous SGDP nest-sites (Taylor \& Cole 2002). The exact study area encompassed the entire Sealers bay dunes and was limited by natural borders: the Sealers beach in the north, forest in the south and the east, and a creek in the west. The size of the study area was approx. 100 x $900 \mathrm{~m}$.

\section{Assessment of burrow occupancy and breeding success}

I searched for burrows during the first 10 days of field work (early November 2015) by walking the length of the study area. I assessed the occupancy of identified burrows using stick palisades, which were checked twice a week. To account for false positives (Taylor et al. 2012), I only considered burrows with three or more records of disturbed palisades as active. I then used hand captures and playback to confirm that SGDPs were the species occupying the burrows (Taylor \& Cole 2002). To assess burrow abandonment, I continued to check stick palisades twice a week until late December 2015.

During a repeat visit in late January 2016, I assessed the success (i.e. producing fledgings) of all SGDP burrows using daily monitoring with stick palisades (Taylor \& Cole 2002). I assumed burrows to have chicks close to fledging when repeated signs of activity (disturbed palisades) were recorded. I assumed that burrows successfully produced fledglings, if active burrows seized to show signs of activity in late January 2016.

\section{Remote camera pilot study}

I assessed the most suitable settings in Bushnell Trophy Cam ${ }^{\mathrm{TM}}$ Trail Cameras (Model 119436; Bushnell Outdoor Technology 2011) for long-term monitoring of SGDP burrows using 10 cameras in early November 2015. This initial round of testing showed that these cameras recorded almost indefinitely throughout the day, potentially due to the high temperature differences in dunes affecting the Passive 
Infrared (PIR) sensor of the camera (Bushnell Outdoor Technology 2011). This caused memory cards to fill up within days. In addition, SGDPs appeared to enter/leave their burrows in seconds, without lingering at burrow entrances. Therefore, I decided to use the following settings for long-term monitoring at SGDP burrows: 5 second video recordings, 60 second break period and "medium" sensitivity (Bushnell Outdoor Technology 2011).

\section{Assessment of interactions at burrows}

I deployed 20 cameras to assess the interactions of various species with SGDP burrows. I randomly selected 15 occupied SGDP burrows. Five additional cameras were placed at burrows that were occupied by birds fitted with RFID tags (see below). This selection of monitored burrows spanned the whole length of the study area. I monitored all 20 burrows from mid-November 2015 to late January 2016 (54-61 monitoring nights) and consequently, covered the entire presumed chick rearing period (Taylor 2013) with a cumulative total of 1121 monitoring nights. I replaced all memory cards and downloaded data on a weekly basis. I replaced broken or malfunctioning cameras when necessary.

\section{Assessment of remote cameras for monitoring}

I captured SGDPs by hand at burrow entrances to equip birds with RFID tags to assess SGDP detection rates of remote cameras. When the burrow surroundings were feasible for RFID reader placement (e.g., flat ground with relatively stable soils), I attached a small (12 x 2.5 mm) RFID tag (Allflex ${ }^{\text {tm }}$ P/N, ISO FDX-B). I placed RFID tags externally on the left tarsus using wrap-around colour bands, as previous attempts at internal RFID placement resulted in excessive bleeding in SGDPs (Trainor 2009). Due to low success rates of hand capture, only five birds from different burrows were fitted with an RFID tag. Considerable amount of time was invested in capturing the partner of these five birds, but without success. RFID tagged birds were marked with a lateral stripe on the crown using Wite-Out ${ }^{\circledR}$ to allow individual recognition on remote cameras. None of the tagged birds showed any change in behaviour.

After birds were equipped with RFID tags, I deployed five remote cameras and five RFID readers in a paired setup at their burrows. I used small, light-weight, waterproof, custom-made RFID readers as used in Taylor et al. (2012). The internal 
settings of these readers allow for adjustment of the recording time and I set them to record from $2100 \mathrm{~h}$ to $0600 \mathrm{~h}$. In addition, I programmed the RFID readers to read for potential tags every 0.1 second to ensure maximum detectability. I built customised RFID reader antennas using transformer-winding, copper wire on site following Taylor et al. (2012), to ensure appropriate correspondence with the RFID tags $(134200 \mathrm{~Hz})$. The reading frequency of the antennas was checked weekly to ensure it remained constant (Taylor et al. 2012). The RFID readers ran on $12 \mathrm{~V}$ batteries, which were replaced on a weekly basis. I monitored SGDP burrows with RFID readers for 28-34 nights from mid-November to late December 2015.

\section{Data analysis}

To assess interspecific interactions at SGDP burrows, I checked all videos recorded between sunset and sunrise, as SGDPs arrive at their burrows after sunset and return to sea before sunrise (Taylor \& Cole 2002). I recorded activities of all species detected at SGDP burrow entrances and categorised activities based on the interaction with SGDP burrows: neutral (i.e. no perceivable interaction with the SGDP burrow), investigative (e.g., inspecting the burrow entrance) and interfering (i.e. competition or predation). I considered multiple videos of a certain species (other than SGDP) in a single night as one record. To assess the effect of these interactions on SGDP breeding success, I linked the recorded interaction to stick palisades records.

To assess the use of remote cameras for SGDP breeding biology monitoring, I compared the time RFID readers recorded SGDP activity with the time of remote camera records. SGDP records with 5 minutes of overlap between remote cameras and RFID readers were considered to pertain to the same record, as both RFID readers and remote cameras can have some error in recording time. Multiple RFID detections within 1 minute were reduced to one record, to account for the 60 second break period of the remote cameras. I considered RFID reader detections as $100 \%$ reliable (Taylor et al. 2012) and calculated remote camera detection rates as a percentage of the RFID detection rates. Birds recorded by cameras, but not by RFID readers were assumed to pertain to the untagged partner, if the Wite-Out ${ }^{\circledR}$ marking was not visible. In addition, as birds may leave burrows too quickly to be recorded on the remote cameras, while still triggering the camera (the used type of remote cameras has a response period of 1 second; Bushnell Outdoor Technology 2011), I considered videos 
without SGDPs that were recorded at the same time as RFID detected SGDP activity as "near-hits". I combined percentages of SGDP detections and "near-hits" to assess the total detection rates of the cameras. Furthermore, I categorised SGDP activity on videos as entering or exiting.

I refrained from statistical analyses as sample sizes were small, but conducted percentage calculations and graphical visualisations using Program $R$ ( $R$ Development Core Team 2016) with the ggplot2 package (Wickham 2009).

\section{RESULTS}

\section{Interactions at burrows}

I obtained 20,897 videos at 20 SGDP burrows during the presumed chick rearing period. Of those videos, 1616 were recorded at night and these revealed 88 videos of seven different species. The most commonly recorded species were Little Blue Penguin (Eudyptula minor) (recorded at 9 burrows; 14 records), Kakapo (Strigops habroptilus) (7 burrows; 9 records), and Blackbird (Turdus merula) (5 burrows; 6 records). CDPs were recorded at two burrows (14 records), while Yellow-eyed Penguins (Megadyptes antipodes), Sooty Shearwaters (Puffinus griseus) and Campbell Island Teals were rare and only recorded at one single burrow. The majority of interspecific interactions recorded at SGDP burrows were neutral (Figure 8). However, Kakapo occasionally showed investigative behaviour (Figure 9A). More importantly, all records of CDPs showed interfering behaviour, which included CDPs entering SGDP burrows, CDPs showing signs indicative of physical conflict, and CDPs collecting nesting material (Figure 9B).

Ten of the 20 monitored SGDP burrows did not successfully produce fledglings. For two of the unsuccessful burrows this was directly linked to the interference of another species, the CDP, as no SGDP activity was recorded after the recorded interfering behaviour. For the other eight unsuccessful SGDP burrows, the cause of abandonment remained unidentified. 


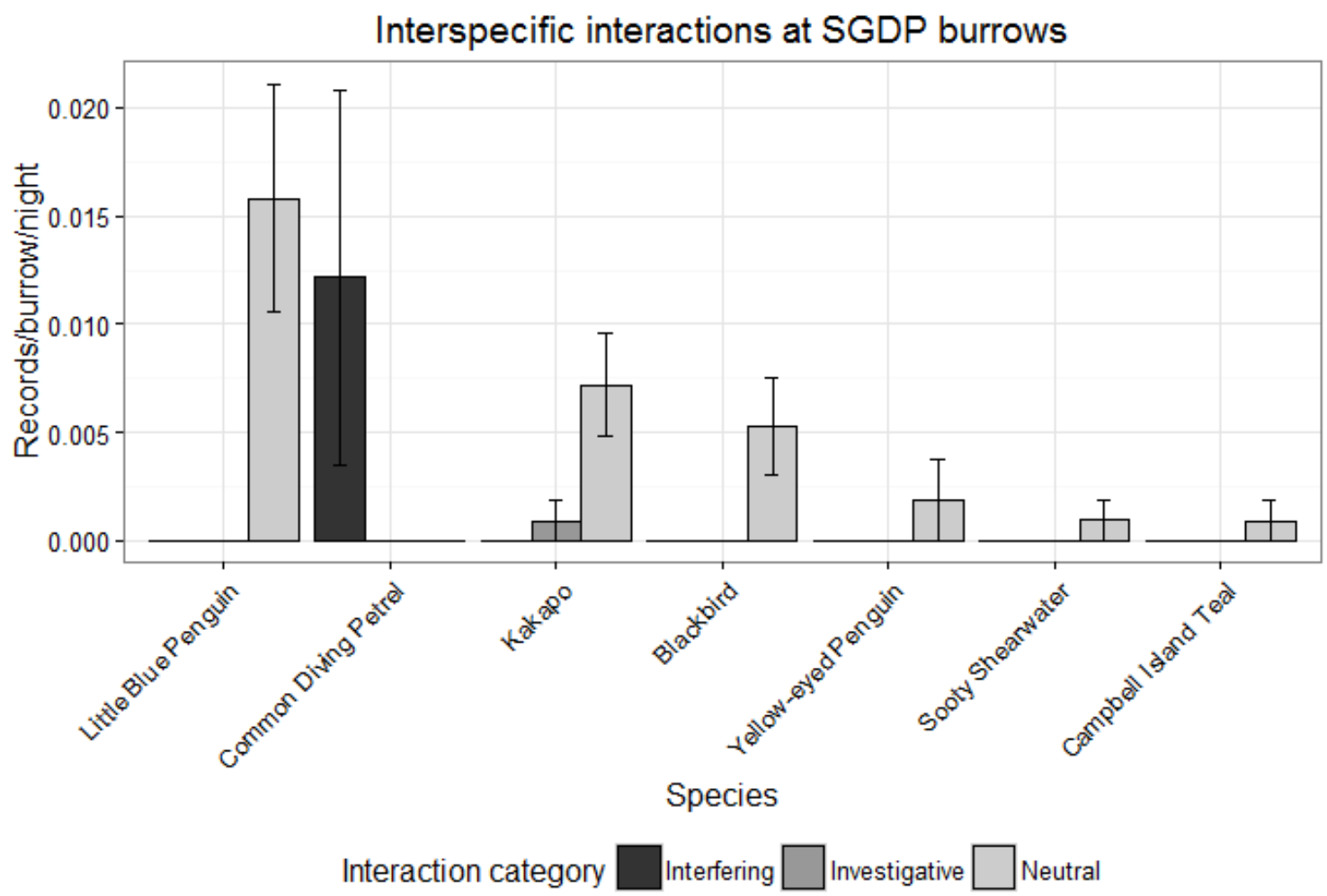

Figure 8. Nature and frequency (mean \pm standard error of mean) of nocturnal interspecific interactions at South Georgian Diving Petrel burrows, as recorded with remote cameras.

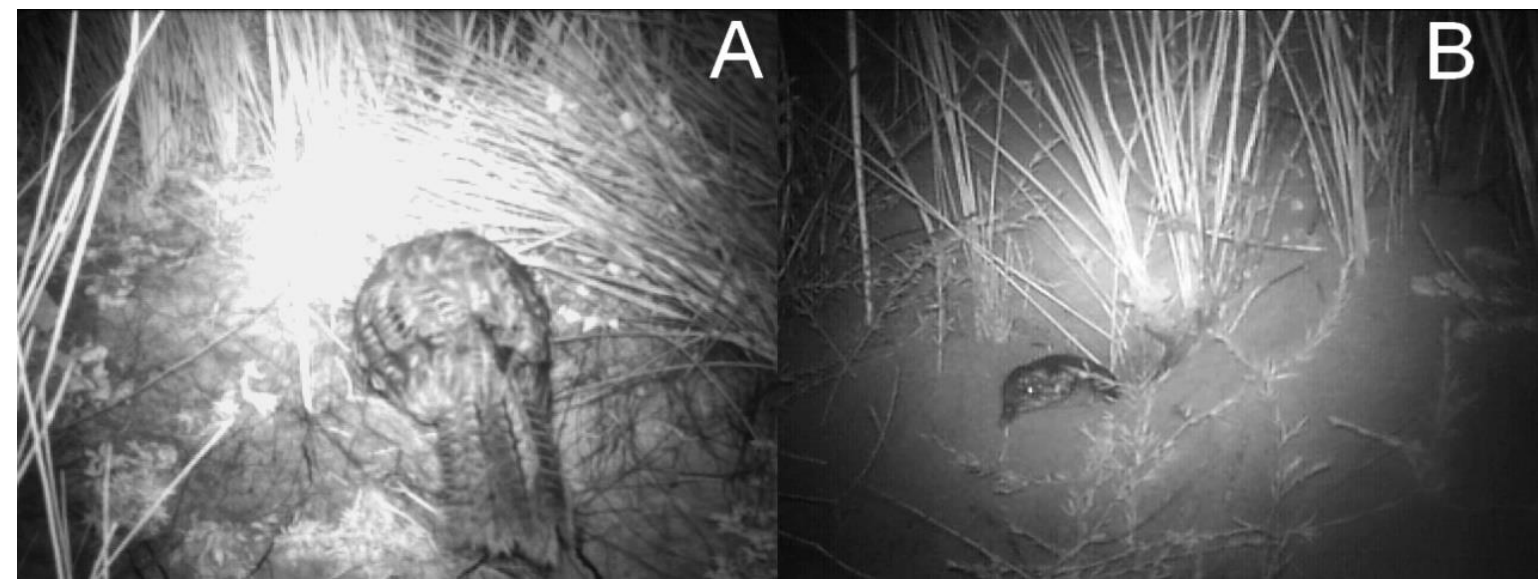

Figure 9. Investigative and interfering behaviour of two species at South Georgian Diving Petrel burrows recorded by remote cameras. 8A shows a Kakapo investigating a burrow entrance. 8B shows a Common Diving Petrel in the burrow entrance, collecting nesting material, and showing with signs of previous physical conflict (as indicated by the disorderly feathers on the side of the head). 


\section{Detection rate of remote cameras}

During the study period, RFID readers detected 33-38 SGDP records at successful burrows $(n=3)$, while RFID readers at unsuccessful burrows $(n=2)$ detected only 812 SGDP records. The nocturnal SGDP activity recorded by RFID readers showed two activity peaks: around $2300 \mathrm{~h}$ and around $0300 \mathrm{~h}$ (Figure 10). Remote cameras detected 3-13 SGDP records at successful burrows and none at unsuccessful burrows. Of the activities detected by remote cameras only two pertained to birds leaving their burrow, while all others $(n=15)$ related to birds entering. Furthermore, the activity patterns revealed by remote cameras differed substantially from the patterns revealed by RFID readers.

When compared to RFID readers, the detection rates of remote cameras were extremely low. Detection rates ranged from $0.00 \%$ to $40.63 \%(\bar{x}=10.86 \% \pm 7.62 \%)$. "Near-hit" rates were slightly higher and ranged from $0.00 \%$ to $47.49 \%$ ( $\bar{x}=24.94 \%$ $\pm 8.99 \%$ ) of RFID reader detections. When combined, the total detection rates ranged from $0.00 \%$ to $62.50 \%(\bar{x}=35.81 \% \pm 16.60 \%)$. No remote camera records of marked birds remained undetected by the RFID readers, indicating accurate detection rates of RFID readers.

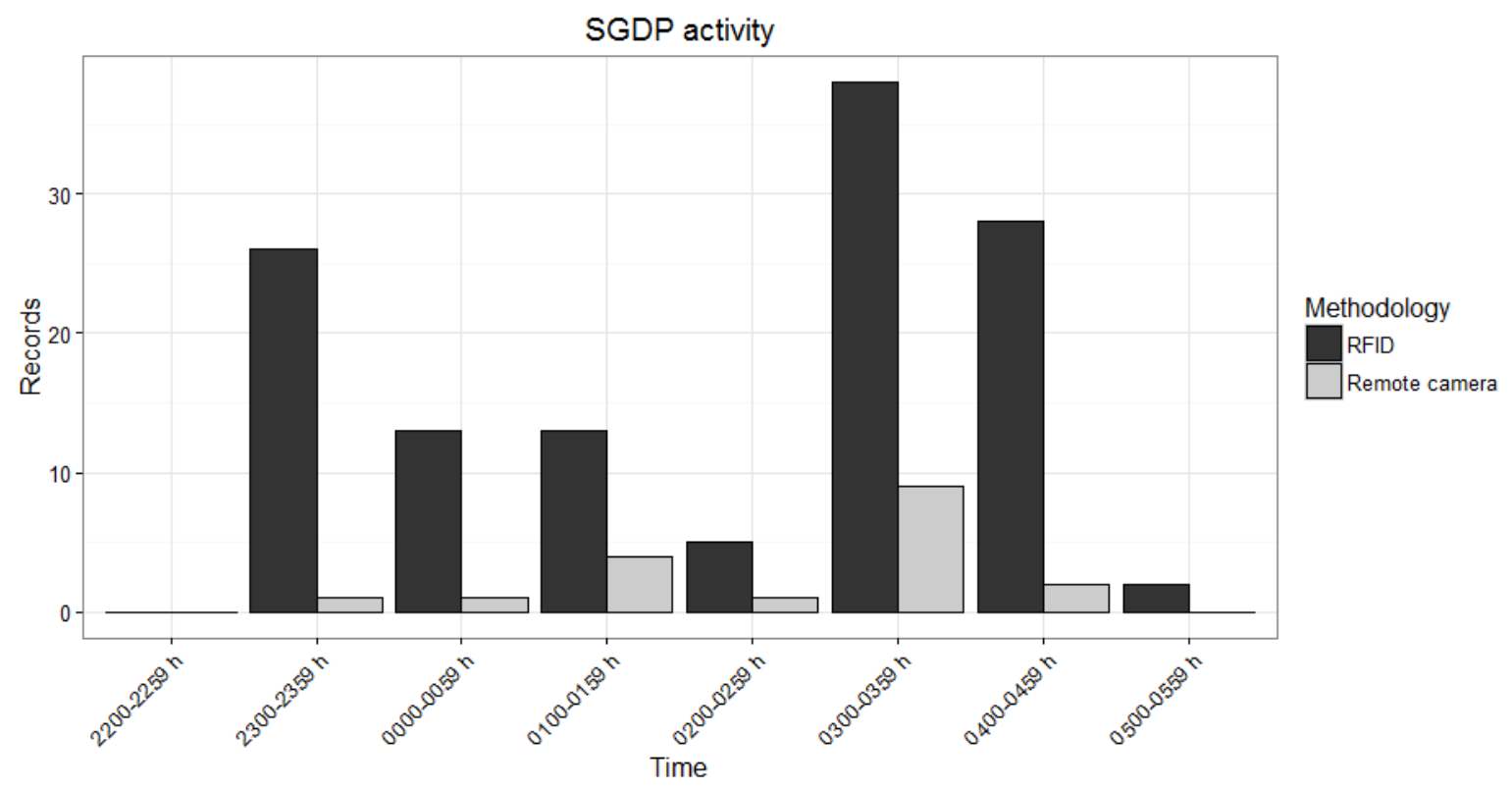

Figure 10. Nocturnal activity of South Georgian Diving Petrels recorded by two noninvasive monitoring methods. 


\section{DISCUSSION}

My results show that several species do occur at, and interact with SGDP burrows, but only two species showed intentional interactions (investigative/interfering), of which only the CDP impacted the breeding success of the SGDPs. These results suggest that remote cameras may be a useful tool to assess the impact of adverse interactions at SGDP burrows. However, my results also show that remote camera detection rates of SGDP activity are extremely low and resulted in questionable activity patterns. Therefore, this non-invasive monitoring method appears unsuitable to study breeding biology and activity patterns in the SGDP.

Monitored SGDP burrows were negatively affected by CDP behaviour. No SGDP activity was recorded at these burrows after the initial records of CDPs, and CDPs were collecting nesting material at these burrows. Data thus suggest that these SGDP burrows were taken over by CDPs. It remains unknown whether or not the recorded interfering behaviour resulted in the mortality of any SGDPs, but it is conceivable that the interaction with CDPs resulted in the failure of these two burrows. Currently, the CDP population is very small (Chapter 3 ) and thus the threat from CDP competition may be only minor. Continued monitoring is needed to assess the CDP population trends within the Sealers bay dunes, and to quantify the potential negative effect on the SGDP. Previous observations suggested that the CDP may be more aggressive than the SGDP (S. Trainor pers. comm. 2016). If the CDP population or records of SGDPCDP competition increase substantially, competition management may be required to safeguard the SGDP population.

Several other species were recorded at SGDP burrows; however, none showed any behaviour with negative effects on SGDP breeding success. Kakapo activity at SGDP burrows was detected comparatively often and the species even investigated burrows, but Kakapo do not appear to pose a threat to SGDP breeding success. The Kakapo is a strictly herbivorous species that has an intricate breeding system with nest-sites in forested habitat (Lloyd \& Powlesland 1993). Therefore, the interest of this species in some SGDP burrows is more likely due to the inquisitive nature of this species (Farrimond et al. 2006). The presence of cameras even may have attracted curious Kakapo to SGDP burrows and therefore elevated the amount of records on remote cameras. In addition, a single record of Campbell Island teal, showing neutral 
behaviour, was made throughout the presumed SGDP chick rearing period. This species is capable of reducing the breeding success of Mottled Petrel (Pterodroma inexpectata) through non-predatory attacks (Sagar et al. 2016). However, the lack of interactions recorded, indicates that teals are not impacting the SGDPs, perhaps because their breeding periods coincide (Heather \& Robertson 2015). Campbell Island Teals may be more reclusive during the breeding period (R. Sagar pers. comm. 2016), potentially reducing encounter rates between teals and SGDPs. Mottled Petrels have a more prolonged breeding season that overlaps less with the Campbell Island Teal breeding season (Heather \& Robertson 2015) and hence encounter rates between these two species may be higher. Alternatively, the small size of SGDP burrows may prevent non-predatory attacks from Campbell Island Teals. Furthermore, remote cameras did not record Moreporks throughout the presumed SGDP chick rearing period. Moreporks predate on small birds (Haw \& Clout 1999), including SGDPs (Trainor 2008). The chick rearing period is likely to be the time when SGDPs are most vulnerable to Morepork predation, as adults enter and exit their burrows virtually every night to feed their chicks (Payne \& Prince 1979, Marchant \& Higgins 1990, Taylor \& Cole 2002). Therefore, the record of SGDP predation by a Morepork (Trainor 2008) may have been incidental and thus Moreporks may not pose a considerable threat to the SGDP population.

Although, remote cameras have low detection rates of SGDP activity, it is probable that interactions between species get recorded because interactions are likely more prolonged than birds entering/exiting burrows. For eight of the unsuccessful monitored burrows the cause remains unknown and this could pertain to interspecific interactions missed by the remote cameras. However, seabird colonies often consist of a mix of breeding birds, unpaired birds, and pre-breeding age prospecting birds, and distinguishing these groups can be difficult (Warham 1996). Therefore, it is more likely that these unsuccessful burrows related to unpaired or prospecting birds, instead of burrows that failed due to undetected interactions. Remote cameras therefore appear a useful tool to assess the effect of interspecific interactions on the breeding of the SGDP, and potentially other small burrowing seabirds.

As useful as remote cameras are to monitor interspecific interactions, the detection of SGDP activity was very low and resulted in inaccurate activity patterns. 
Remote cameras of the used model were thus not suitable to monitor the breeding activities of the SGDP. Potentially, the detection rates were low, because SGDPs enter and leave their burrows quickly, probably to avoid predation (Watanuki 1986, Mougeot \& Bretagnolle 2000). The higher detection rate of SGDPs entering burrows may be explained by the need to clear the burrow entrances of accumulated sand. It should be noted that remote cameras are constantly improving (Swann et al. 2011). Newer models may be less prone to record indefinitely in dune habitats, allowing higher sensitivity settings and may thus be more suitable for the monitoring of SGDPs. Furthermore, remote cameras with Active Infrared (AIR) sensors are also less prone to false triggers, but are substantially more expensive (Kays \& Slauson 2008). The model we used may be more advantageous in other (seabird) species, for most other small burrowing seabird species do not breed in dunes. However, other small burrowing seabird species are likely to enter and leave their burrows equally quickly to avoid predation (Watanuki 1986, Mougeot \& Bretagnolle 2000), which may result in equally low detection rates. Therefore, the use of remote cameras to study breeding biology and activity patterns in small, burrowing seabirds should be considered with care, as this method may not be the most advantageous.

The use of RFID readers for breeding biology monitoring of small petrel species could be further investigated, but study burrows are likely to be the most advantageous method. The disadvantage of RFID readers is that they do not show directionality and thus limit data analysis. Furthermore, the weekly battery changes are labour-intensive and not ideal for long-term monitoring on remote islands. These shortcomings can be overcome by using paired antennas to assess movement directionality and by using solar panels to power RFID readers (Taylor et al. 2012). However, further study of the SGDP with study burrows may provide the most valuable insights. Neither RFID readers nor remote cameras provide data on feeding portions and chick growth rates, for both methods are limited to assessing activity at the burrow entrance. Consequently, the placement of study burrows should be considered to study the breeding biology of the SGDP more in-depth. This technique may be labour intensive, invasive and potentially limited to a selected suit of SGDP burrows in the most stable soils, but this technique will likely provide the most useful breeding biology data. Considering the precarious state of the SGDP in New Zealand, further breeding biology studies appear favourable, especially since certain 
conservation management strategies require detailed breeding biology data (Miskelly \& Taylor 2004).

\section{CONCLUSION}

Remote cameras provide opportunities to assess interspecific interactions at seabird burrows. However, remote cameras may not be the most feasible method to study the breeding biology of small, burrowing seabirds, especially when these breed in dunes like the South Georgian Diving Petrel on Codfish Island. For in-depth breeding biology studies RFID readers with paired antennas may be considered, but study burrows will likely provide the most detailed data on the South Georgian Diving Petrel in particular and small, burrowing seabirds in general. 
Chapter 5 
Chapter 5.

ANALYSIS OF PHENOTYPIC DIFFERENTIATIONS BETWEEN SOUTH

GEORGIAN DIVING PETREL (Pelecanoides georgicus) POPULATIONS

REVEALS AN UNDESCRIBED AND HIGHLY ENDANGERED SPECIES

FROM NEW ZEALAND

\section{ABSTRACT}

$\mathrm{U}^{\mathrm{N}}$ NRESOLVED TAXONOMY OF threatened species is problematic for conservation as the field relies on species as single, distinct, ecological units. New Zealand supports a highly diverse seabird community and their taxonomy is far from resolved. Differences in breeding habitat and results from a preliminary molecular analysis indicated the New Zealand population of the South Georgian Diving Petrel (Pelecanoides georgicus) to be a distinct yet undescribed taxon. I measured 10 biometric characters and scored eight plumage characters in 80 live birds and 53 study skins originating from the majority of the known populations of P. georgicus. I analysed differences with factorial ANOVAs, Kruskal-Wallis rank sum tests, and principal component analyses (PCA). Furthermore, I used a species delimitation test with quantitative phenotypic criteria to address species limits within P. georgicus. Results show that the New Zealand population differs from other populations through: 1) longer wings, 2) longer outer tail feathers, 3) higher bills, 4) longer heads, 5) longer tarsi, 6) limited collar extent, 7) greater extent of contrasting scapulars and, 8) larger contrasting markings on the secondaries. These differences may be linked to different ecological or behavioural traits. The species delimitation test revealed that the New Zealand population merits species status. I hereby propose to name this new species Pelecanoides taylorii sp. nov. Due to severe historic range restrictions and very low number of remaining individuals (approx. 150 individuals limited to Codfish Island (Whenua Hou)) the species warrants listing as Critically Endangered. 
Chapter 5

\section{INTRODUCTION}

Conservation biology remains focussed on species as distinct and single ecological units and thus, accurate taxonomic placement of threatened species is crucial to effective conservation management (May 1990, Sangster et al. 2016). If common, polytypic taxa (i.e., clusters of distinct and diverged species; Griffiths 1974), include unclassified taxonomic units warranting species status, their significance remains "hidden". Valuable time to implement conservation management may consequently be lost if composite "species" ameliorate the actual conservation status of threatened taxa (Sangster et al. 2016). Therefore, the "hidden" rare taxa are unlikely to receive the management required to conserve them.

This phenomenon of "hidden" but endangered taxa is common on archipelagos and many distinct and endemic taxa on (single) islands are consequently underappreciated (Sangster et al. 2016). For instance, the taxonomy of many species complexes on the archipelago of New Zealand remains unresolved (e.g., May 1990, Bell et al. 1998, Hay et al. 2010). Especially New Zealand's diverse seabird community, the most threatened seabird community in the world (Croxall et al. 2012), remains in taxonomic flux (e.g., Penhallurick \& Wink 2004, Rheindt \& Austin 2005, Rawlence et al. 2016, Wood et al. 2016) and several undescribed and threatened seabird taxa may remain within polytypic seabird "species" in New Zealand.

The South Georgian Diving Petrel (Pelecanoides georgicus; Murphy \& Harper 1916) is an example of a potentially polytypic seabird taxon that is currently considered monotypic (Gill et al. 2010), but may include a highly threatened and distinct taxon (Paterson et al. 2000). This Procellariiform species occurs across the southern hemisphere with breeding colonies on South Georgia (U.K.), Prince Edward Island (South Africa), Crozet Islands (France), Kerguelen Islands (France), Heard Island (Australia) and Codfish Island (Whenua Hou) (New Zealand) (Marchant \& Higgins 1990, Figure 11). Other additional colonies were extirpated including colonies on Marion Island (South Africa), Macquarie Island (Australia), Auckland Islands (New Zealand), Chatham Islands (New Zealand), Stewart Island (New Zealand), and the South Island of New Zealand (Marchant \& Higgins 1990, Taylor 2000, Wood \& Briden 2008). Ecological, molecular and osteological data highlight the possibility that the New Zealand P. georgicus population may be a distinct species. For 
example, $P$. georgicus in New Zealand prefer coastal sand dunes at sea level for breeding (Taylor 2000, Chapter 3), rather than scree at high altitude as other populations do (Payne \& Prince 1979, Marchant \& Higgins 1990). In addition, results of a preliminary molecular analysis suggest that the New Zealand population diverged from P. georgicus populations in the Southern Indian Ocean several 100,000 years ago, and is indeed distinct (Paterson et al. 2000). Furthermore, osteological analyses revealed differences between P. georgicus populations (Worthy 1998). The debate surrounding the taxonomic status of P. georgicus in New Zealand has resulted in considerable confusion in the literature (Scofield \& Stephenson 2013). While $P$. georgicus is considered of Least Concern globally (IUCN 2016), the New Zealand population is highly threatened (Taylor 2000) and is currently classified as Nationally Critical (Robertson et al. 2013).

In order to resolve the taxonomic status of the threatened relict population of P. georgicus population in New Zealand, I assessed differences in 10 biometric and eight plumage characters and addressed species limits within P. georgicus using a species delimitation test with quantitative phenotypic criteria (Tobias et al. 2010). 
Chapter 5

\section{METHODS}

\section{Taxonomy}

I adhere here to the taxonomy of Gill et al. (2010) in which P. georgicus is considered monotypic and a member of the Pelecanoididae family (order: Procellariiformes).

\section{Origin of samples}

I assessed biometric and plumage differences between P. georgicus populations using 80 live birds and 53 study skins, covering the majority of the range of the species (Marchant \& Higgins 1990; Figure 11). I measured and photographed live birds on Codfish Island, New Zealand $(n=64)$. Furthermore, I used measurements from live birds from Ile aux Cochons, Kerguelen Islands $(\mathrm{n}=16)$ (Bost, Fromant \& Miskelly unpub. data 2015). In addition, I measured and photographed study skins deposited in Te Papa Tongarewa Museum of New Zealand, Wellington (NMNZ). NMNZ study skins originated from: South Georgia $(n=4)$, Marion Island $(n=1)$, Crozet Islands ( $=3)$, Kerguelen Islands $(n=12)$, Heard Island $(n=10)$, Codfish Island $(n=10)$ and Dundas, Auckland Islands $(\mathrm{n}=1)$. To increase my sample sizes, I requested further data and photographs from study skins from the American Museum of Natural History, New York, U.S.A. (AMNH) and the British Museum of Natural History, Tring, U.K. $(B M N H)$. AMNH study skins originated from South Georgia $(n=5)$. BMNH study skins originated from South Georgia $(n=3)$, Marion Island $(n=1)$, Crozet Islands $(n=$ 2) and Auckland Islands ( $\mathrm{n}=1)$. Six study skins at BMNH (11.6.1861, 01.9.1861, 1949.51.7, 1938.12.19.102, 1940.12.7.45 and 1991.25.1) were originally labelled as Common Diving Petrel (P. urinatrix exsul/coppingeri). I concluded that these skins were in fact P. georgicus based on bill morphology (e.g., convergent bill sides and pointed arch; Onley \& Scofield 2007) and included samples in my analysis. In total, my sample size included 80 live birds and 53 study skins. 


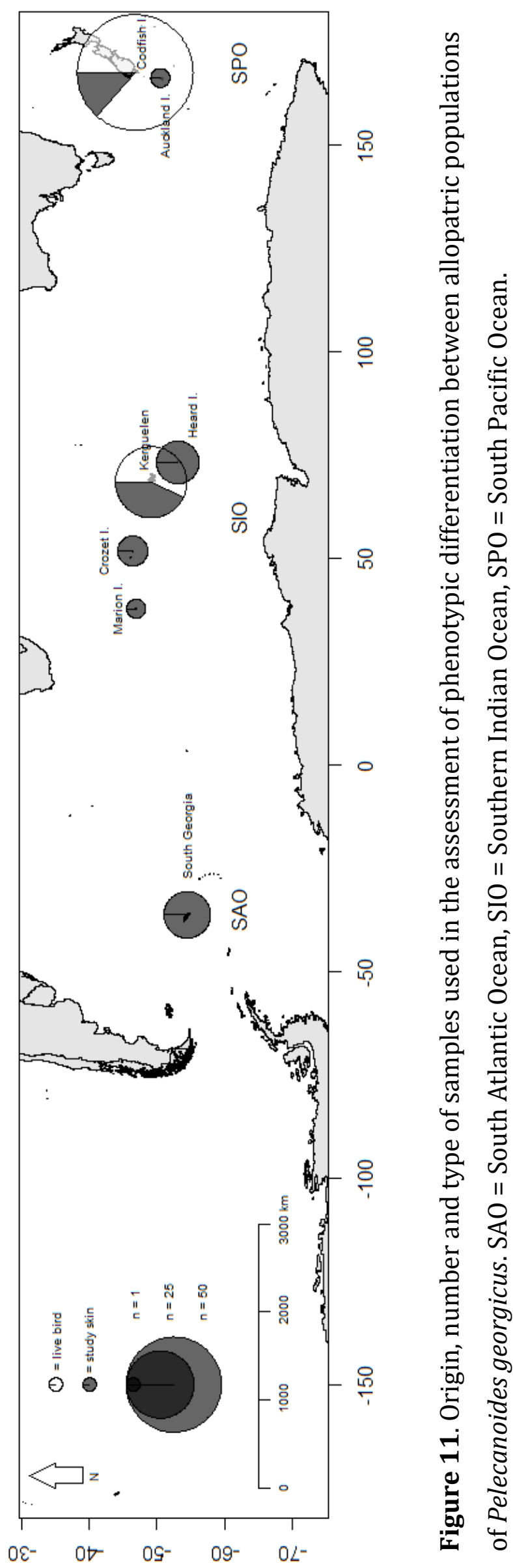




\section{Biometric characters}

I compared 10 biometric variables between populations. Nine different biometric variables were measured (Table 11). In addition, I used the difference between T1 and T6 to enable quantitative assessment of tail fork depth. Measurements were rounded to the nearest $\mathrm{mm}$ for wing and tail measurements and to the nearest $0.1 \mathrm{~mm}$ for all other measurements. Where applicable, measurements were taken on the right side of the bird. Measurements originated from several different researchers and to counter a potential measuring bias, a short video illustrating the precise measuring methodology was provided (https://youtu.be/gyInRYWONKY).

\section{Plumage characters}

I created a semi-standardised photo archive of live $P$. georgicus and study skins and assessed five ordinal plumage characters: contrasting ear-covert extent (1-4; Figure 12A), collar extent (1-4; Figure 12B), contrasting white scapular extent (1-4; Figure 12C), shape of white markings on all secondaries (1-4; Figure 13) and extent of white markings on all secondaries (S1-S10) (1-5; Figure 13). In addition, I recorded the colour of the contrasting ear coverts, collar, and flank on a scale $(1-5 ; 1=$ white, $5=$ black). I refrained from using a colour chart, as this tool is not helpful with colours fading into each other (Collar \& Marsden 2014). In several taxonomic studies plumage characters are scored on larger scales (e.g., 1-10; Alström et al. 2015, 2016). I refrained from using such scales as they come with the arguable difficulty of distinguishing between neighbouring classes. 
Table 9. Definitions and measuring tools of biometric variables used in data collection for analyses of biometric differentiations between Pelecanoides georgicus populations.

\begin{tabular}{|c|c|c|}
\hline $\begin{array}{l}\text { Biometric } \\
\text { variable }\end{array}$ & $\begin{array}{l}\text { Measuring } \\
\text { tool }\end{array}$ & Definition \\
\hline Wing length & Wing ruler & $\begin{array}{l}\text { Flattened wing chord from carpal joint to longest } \\
\text { primary. }\end{array}$ \\
\hline Length of $\mathrm{T} 6$ & Tail ruler & $\begin{array}{l}\text { Distance from point of insertion to tip of the outermost } \\
\text { tail feather (T6). }\end{array}$ \\
\hline Length of T1 & Tail ruler & $\begin{array}{l}\text { Distance from point of insertion to tip of the innermost } \\
\text { tail feather (T1). }\end{array}$ \\
\hline Bill length & $\begin{array}{l}\text { Dial/vernier } \\
\text { callipers }\end{array}$ & $\begin{array}{l}\text { Distance on a horizontal plane from front curve of } \\
\text { upper mandible to distalmost crown feathers. }\end{array}$ \\
\hline Bill width & $\begin{array}{l}\text { Dial/vernier } \\
\text { callipers }\end{array}$ & Width at distalmost crown feathers. \\
\hline Bill height & $\begin{array}{l}\text { Dial/vernier } \\
\text { callipers }\end{array}$ & $\begin{array}{l}\text { Height (depth) of both mandibles at the distalmost } \\
\text { crown feathers, including nostrils (nasal tubes). }\end{array}$ \\
\hline Arch length & $\begin{array}{l}\text { Dial/vernier } \\
\text { callipers }\end{array}$ & $\begin{array}{l}\text { Distance from the apex of the lower mandible arch to } \\
\text { the distalmost throat feathers. }\end{array}$ \\
\hline Head length & $\begin{array}{l}\text { Dial/vernier } \\
\text { callipers }\end{array}$ & $\begin{array}{l}\text { Distance from the front curve of upper mandible to the } \\
\text { supraoccipital. }\end{array}$ \\
\hline Tarsus length & $\begin{array}{l}\text { Dial/vernier } \\
\text { callipers }\end{array}$ & $\begin{array}{l}\text { Distance from the notch between the digits and the } \\
\text { tarsometatarsus to the notch between the } \\
\text { tarsometatarsus and the tibia. }\end{array}$ \\
\hline
\end{tabular}


A

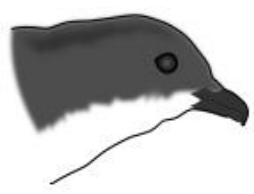

1

B

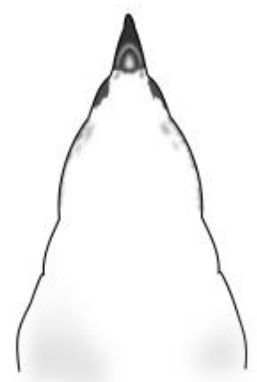

1

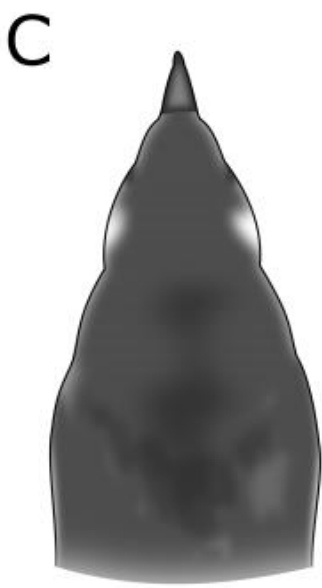

1

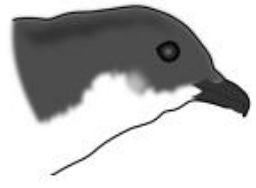

2

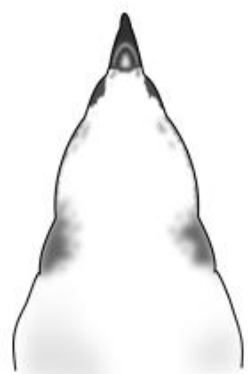

2

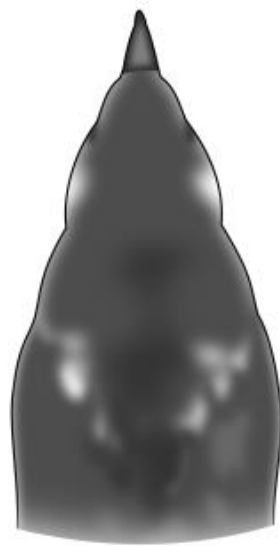

2

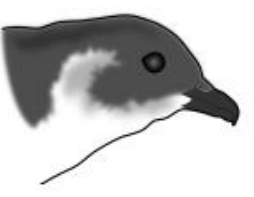

3

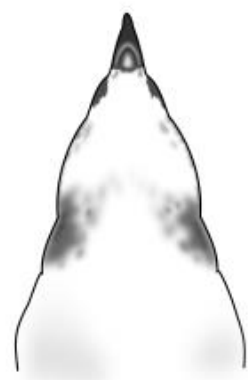

3

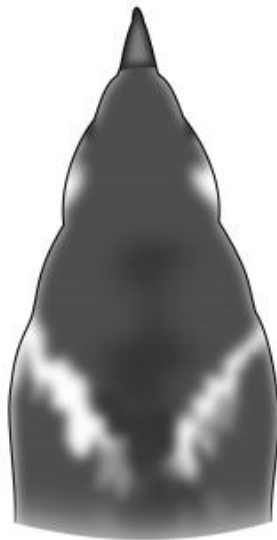

3

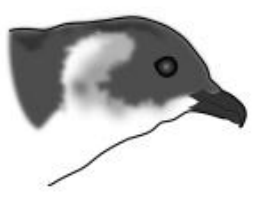

4

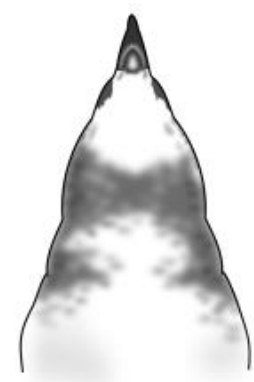

4

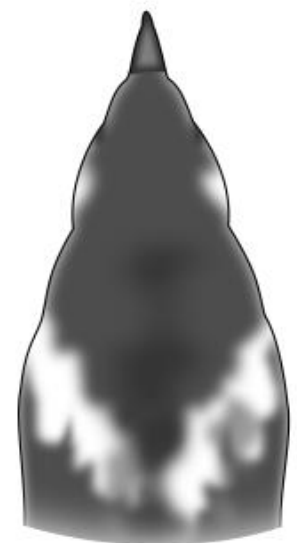

4

Figure 12. Scale of variation in plumage characters of Pelecanoides georgicus used to assess plumage scores. 11A: extent of contrasting ear coverts $(1=$ absent, $4=$ reaching over the eye). 11B: Extent of collar ( 1 = absent, 4 = fully connected). 11C: Extent of contrasting scapulars ( 1 = absent, 4 = prominent and virtually connected). 
1

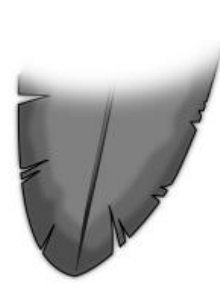

2
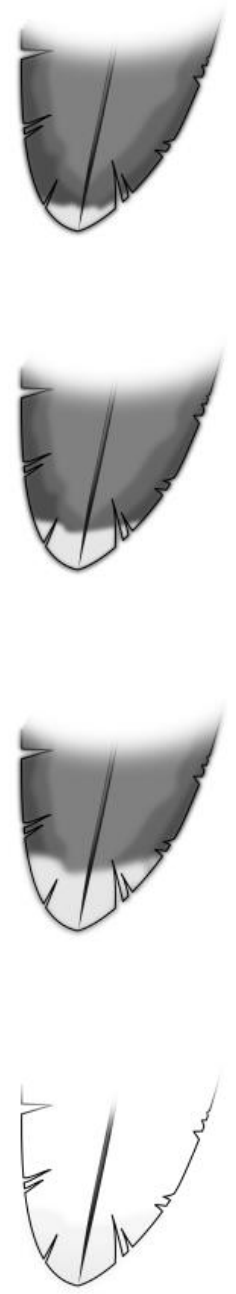

3

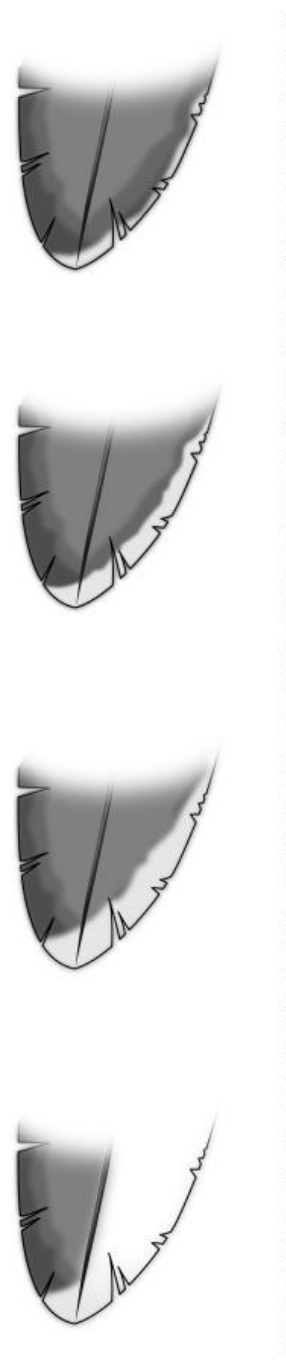

4
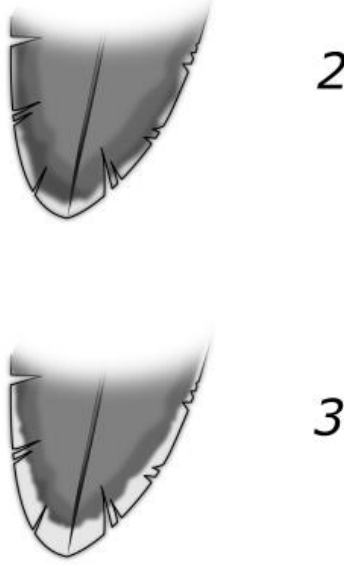

3

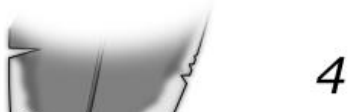

4

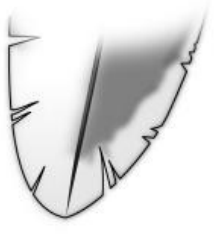

3

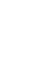

2

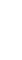

5

Figure 13. Matrix used to score variation in the shape of contrasting markings (horizontal; 1 = absent, 4 = present on tip, inner and outer vane) and extent of contrasting markings (vertical; 1 = absent, 5 = covering at least one vane entirely) on all secondaries in different Pelecanoides georgicus populations. 


\section{Data analysis}

I pooled samples of P. georgicus into three allopatric populations: South Atlantic Ocean (SAO; $n=12$ ), South Indian Ocean (SIO; $n=45$ ) and South Pacific Ocean (SPO; $\mathrm{n}=76$ ) (Onley \& Scofield 2007) (Figure 11). I then compared biometric measurements and plumage scores between these pools. I excluded all juvenile birds $(\mathrm{SAO}=0, \mathrm{SIO}=8, \mathrm{SPO}=3)$ from the analyses to account for potential biases created by incomplete feather growth/development. I also excluded T6 and T1 measurements from birds showing active tail moult $(\mathrm{SAO}=0$, SIO $=5$, SPO $=4)$. Furthermore, I accounted for potential differences between live birds and study skins (e.g., through shrinkage or fading; Kinsky \& Harper 1968, Harris 1980) by using Welch's twosample t-tests with the SPO pool as a subset (as this pool had the largest sample size). Based on results from this analysis, I excluded measurements of wing length $(t=$ 2.161, $d f=15.026, p=0.047)$ and bill height $(t=-6.149, d f=14.044, p<0.001)$ as well as plumage scores of the extent of contrasting ear-coverts $(t=-3.371, d f=12.242, p=$ $0.005)$ and collar colour $(t=2.197, d f=13.437, p=0.046)$ from live birds from subsequent analyses. As few samples were sexed, sexual dimorphism was not taken into account. I then assessed differences in biometric measurements using factorial ANOVAs and Tukey HSD tests (Collar \& Marsden 2014). I assessed differences in plumage characters with Kruskal-Wallis rank sum tests and made pair-wise comparisons with Welch's two-sample t-tests with Bonferroni corrections (Alström et al. 2015, 2016). In addition, I preformed two principal component analyses (PCA): one for biometric measurements and one for plumage scores. Missing values were replaced with the means of each pool, and data were log transformed before executing a PCA (Quinn \& Keough 2002).

I addressed the potential species status of the three allopatric populations using a species delimitation test with quantitative phenotypic criteria (Tobias et al. 2010), in which biometric, bioacoustic, plumage and behavioural/ecological characters can be scored. Characters with continuous data (e.g., biometric and bioacoustic data) were scored based on Cohen's $d$ effect sizes $(d=0.2-2.0=$ score of 1 , $d=2.0-5.0=$ score of $2, d=5.0-10.0=$ score of $3, d>10.0=$ score of 4 ). Nominal, ordinal and interval data (e.g., plumage and behavioural characters) were scored more subjectively. An "exceptional" character (e.g., a completely different colour in most of the plumage) received a score of 4, a "strong" character (e.g., a contrastingly different 
colour in most of the plumage) a score of 3, a "medium" character (e.g., a slightly different colour in a significant part of the plumage) a score of 2, and a "weak" character (e.g., a different shade in part of the plumage) a score of 1 . Three plumage, two bioacoustic, two biometric and one behavioural/ecological character can then be summed. If the sum exceeded a score of 7 , species status is warranted. Species status could not be achieved by scoring only "weak" characters. As I restricted the analysis differentiations within the P. georgicus complex to biometric and plumage characters, I summed three plumage characters, two biometric characters and added one behavioural/ecological character to address species limits within P. georgicus.

All analyses were conducted in Program R (R Development Core Team 2016) using the effsize (Torchiano 2016) package. PCAs were visualised using the ggplot2 (Wickham 2009) and ggfortify (Horikoshi \& Tang 2016) packages.

\section{RESULTS}

Univariate statistics for 10 biometric measurements and eight plumage scores from each allopatric P. georgicus population can be found in Table 12.

\section{Biometric characters}

Results of factorial ANOVAs revealed differences in wing length $\left(f_{2,39}=7.643, p=\right.$ 0.002), T6 length $\left(f_{2,92}=16.154, p<0.001\right)$, T1 length $\left(f_{2,87}=11.986, p<0.001\right)$, bill height $\left(f_{2,37}=11.827, p<0.001\right)$, head length $\left(f_{2,112}=15.994, p<0.001\right)$ and tarsus length $\left(f_{2,113}=15.626, p<0.001\right)$. Results of pairwise comparisons using Tukey HSD tests revealed two groups within $P$. georgicus that can be readily distinguished: the SAO/SIO group and the SPO group (Table 12 \& Figure 14). Results from a PCA showed that there is considerable overlap in biometric measurements between the SAO and SIO, but only limited overlap between the SAO and SPO populations and very little overlap between the SIO and SPO populations (Table 13 \& Figure 15A). 
Table 10. Mean \pm standard error of mean (minimum-maximum; $n$ ) and univariate statistics for biometric measurements (in $\mathrm{mm}$ ) and plumage scores in allopatric Pelecanoides georgicus populations $(\mathrm{SAO}=$ South Atlantic Ocean, $\mathrm{SIO}=$ Southern Indian Ocean, SPO = South Pacific Ocean). Pair-wise comparisons were conducted with Tukey HSD tests for biometric measurements and Welch two-sample t-tests with Bonferroni corrections for plumage scores. Blank indicates $p>0.05, *$ indicates $p<$ 0.05 , ${ }^{* *}$ indicates $p<0.01$ and ${ }^{* * *}$ indicates $p<0.001$.

\begin{tabular}{|c|c|c|c|c|c|c|}
\hline Character & SAO & SIO & SPO & $\begin{array}{l}\text { SAO } \\
\text { vs. } \\
\text { SIO }\end{array}$ & $\begin{array}{l}\text { SAO } \\
\text { vs. } \\
\text { SPO }\end{array}$ & $\begin{array}{l}\text { SIO } \\
\text { vs. } \\
\text { SPO }\end{array}$ \\
\hline \multicolumn{7}{|l|}{$\begin{array}{l}\text { Biometric } \\
\text { measurement }\end{array}$} \\
\hline Wing length & $\begin{array}{l}115.75 \pm 1.15 \\
(111-124 ; 12)\end{array}$ & $\begin{array}{c}116.16 \pm 0.84 \\
(109-122 ; 19)\end{array}$ & $\begin{array}{r}121.27 \pm 0.71 \\
(117-125 ; 11)\end{array}$ & & $* *$ & $* *$ \\
\hline Length of $\mathrm{T} 6$ & $\begin{array}{r}38.98 \pm 1.15 \\
(30-45 ; 12)\end{array}$ & $\begin{array}{r}36.81 \pm 0.71 \\
(32-40 ; 13)\end{array}$ & $\begin{array}{r}41.07 \pm 0.29 \\
(37-48 ; 69)\end{array}$ & & $*$ & $* * *$ \\
\hline Length of T1 & $\begin{array}{r}35.61 \pm 0.70 \\
(31-39 ; 12)\end{array}$ & $\begin{array}{r}33.90 \pm 0.57 \\
(31-37 ; 13)\end{array}$ & $\begin{array}{r}37.40 \pm 0.32 \\
(34-47 ; 65)\end{array}$ & & & $* * *$ \\
\hline Tail fork depth & $\begin{array}{l}3.37 \pm 1.24 \\
(-4-11 ; 12)\end{array}$ & $\begin{array}{r}2.66 \pm 0.36 \\
(0-5 ; 13)\end{array}$ & $\begin{array}{r}3.72 \pm 0.24 \\
(0-10 ; 65)\end{array}$ & & & \\
\hline Bill length & $\begin{array}{r}14.09 \pm 0.27 \\
(12.3-15.8 ; 12)\end{array}$ & $\begin{array}{r}14.10 \pm 0.26 \\
(11.4-17.4 ; 35)\end{array}$ & $\begin{array}{r}14.08 \pm 0.14 \\
(11.0-17.4 ; 69)\end{array}$ & & & \\
\hline Bill width & $\begin{array}{r}8.78 \pm 0.36 \\
(6.7-11.3 ; 12)\end{array}$ & $\begin{array}{r}8.42 \pm 0.08 \\
(7.6-9.5 ; 35)\end{array}$ & $\begin{array}{r}8.56 \pm 0.05 \\
(7.8-10.0 ; 69)\end{array}$ & & & \\
\hline Bill height & $\begin{array}{r}7.50 \pm 0.12 \\
(6.9-8.2 ; 11)\end{array}$ & $\begin{array}{r}7.74 \pm 0.16 \\
(6.7-9.5 ; 19)\end{array}$ & $\begin{array}{r}8.71 \pm 0.20 \\
(7.8-9.4 ; 10)\end{array}$ & & $* * *$ & $* * *$ \\
\hline Arch length & $\begin{array}{l}5.80 \pm 0.24 \\
(5.0-6.9 ; 7)\end{array}$ & $\begin{array}{r}5.24 \pm 0.15 \\
(3.8-6.2 ; 18)\end{array}$ & $\begin{array}{r}5.55 \pm 0.22 \\
(4.3-6.5 ; 10)\end{array}$ & & & \\
\hline Head length & $\begin{array}{r}49.49 \pm 0.62 \\
(46.4-53.4 ; 11)\end{array}$ & $\begin{array}{r}49.33 \pm 0.52 \\
(36.7-56.5 ; 35)\end{array}$ & $\begin{array}{r}51.73 \pm 0.19 \\
(45.1-55.5 ; 69)\end{array}$ & & $* * *$ & $* * *$ \\
\hline Tarsus length & $\begin{array}{r}23.63 \pm 0.84 \\
(19.3-27.2 ; 12) \\
\end{array}$ & $\begin{array}{r}24.36 \pm 0.18 \\
(22.0-26.1 ; 35) \\
\end{array}$ & $\begin{array}{r}25.60 \pm 0.14 \\
(22.9-28.6 ; 69) \\
\end{array}$ & & $* * *$ & $* * *$ \\
\hline \multicolumn{7}{|l|}{ Plumage score } \\
\hline $\begin{array}{l}\text { Contrasting ear } \\
\text { covert extent (1-4) }\end{array}$ & $\begin{array}{r}3.42 \pm 0.19 \\
(2-4 ; 12)\end{array}$ & $\begin{array}{r}3.19 \pm 0.15 \\
(2-4 ; 21)\end{array}$ & $\begin{array}{r}3.18 \pm 0.18 \\
(2-4 ; 11)\end{array}$ & & & \\
\hline Collar extent (1-4) & $\begin{array}{r}2.58 \pm 0.22 \\
(2-4 ; 12)\end{array}$ & $\begin{array}{r}3.48 \pm 0.18 \\
(2-4 ; 21)\end{array}$ & $\begin{array}{r}1.69 \pm 0.08 \\
(1-3 ; 58)\end{array}$ & $* *$ & $* *$ & $* * *$ \\
\hline $\begin{array}{l}\text { Contrasting } \\
\text { scapular extent (1- } \\
\text { 4) }\end{array}$ & $\begin{array}{r}2.33 \pm 0.23 \\
(1-4 ; 12)\end{array}$ & $\begin{array}{r}2.00 \pm 0.16 \\
(1-4 ; 21)\end{array}$ & $\begin{array}{r}3.16 \pm 0.09 \\
(2-4 ; 62)\end{array}$ & & $* *$ & $* * *$ \\
\hline $\begin{array}{l}\text { Contrasting } \\
\text { secondary marking } \\
\text { extent }(1-5)\end{array}$ & $\begin{array}{l}2.17 \pm 11 \\
(2-3 ; 12)\end{array}$ & $\begin{array}{r}2.00 \pm 0.10 \\
(1-3 ; 21)\end{array}$ & $\begin{array}{r}3.11 \pm 0.10 \\
(2-5 ; 62)\end{array}$ & & $* * *$ & $* * *$ \\
\hline $\begin{array}{l}\text { Contrasting } \\
\text { secondary marking } \\
\text { shape (1-4) }\end{array}$ & $\begin{array}{r}3.08 \pm 0.15 \\
(2-4 ; 12)\end{array}$ & $\begin{array}{r}3.75 \pm 0.16 \\
(1-4 ; 20)\end{array}$ & $\begin{array}{r}4.00 \pm 0.00 \\
(4-4 ; 62)\end{array}$ & $* *$ & $* * *$ & \\
\hline $\begin{array}{l}\text { Contrasting ear } \\
\text { covert colour (1-5) }\end{array}$ & $\begin{array}{r}3.08 \pm 0.19 \\
(2-4 ; 12)\end{array}$ & $\begin{array}{r}3.24 \pm 0.10 \\
(3-4 ; 21)\end{array}$ & $\begin{array}{r}2.65 \pm 0.06 \\
(2-4 ; 63)\end{array}$ & & & $* * *$ \\
\hline Collar colour (1-5) & $\begin{array}{r}2.75 \pm 0.13 \\
(2-3 ; 12)\end{array}$ & $\begin{array}{r}3.00 \pm 0.00 \\
(3-3 ; 21)\end{array}$ & $\begin{array}{r}2.45 \pm 0.28 \\
(1-3 ; 11)\end{array}$ & & & \\
\hline Flank colour (1-5) & $\begin{array}{r}1.83 \pm 0.31 \\
(2-3 ; 6) \\
\end{array}$ & $\begin{array}{r}2.50 \pm 0.12 \\
(2-3 ; 18) \\
\end{array}$ & $\begin{array}{r}1.92 \pm 0.08 \\
(1-3 ; 52) \\
\end{array}$ & & & $* * *$ \\
\hline
\end{tabular}



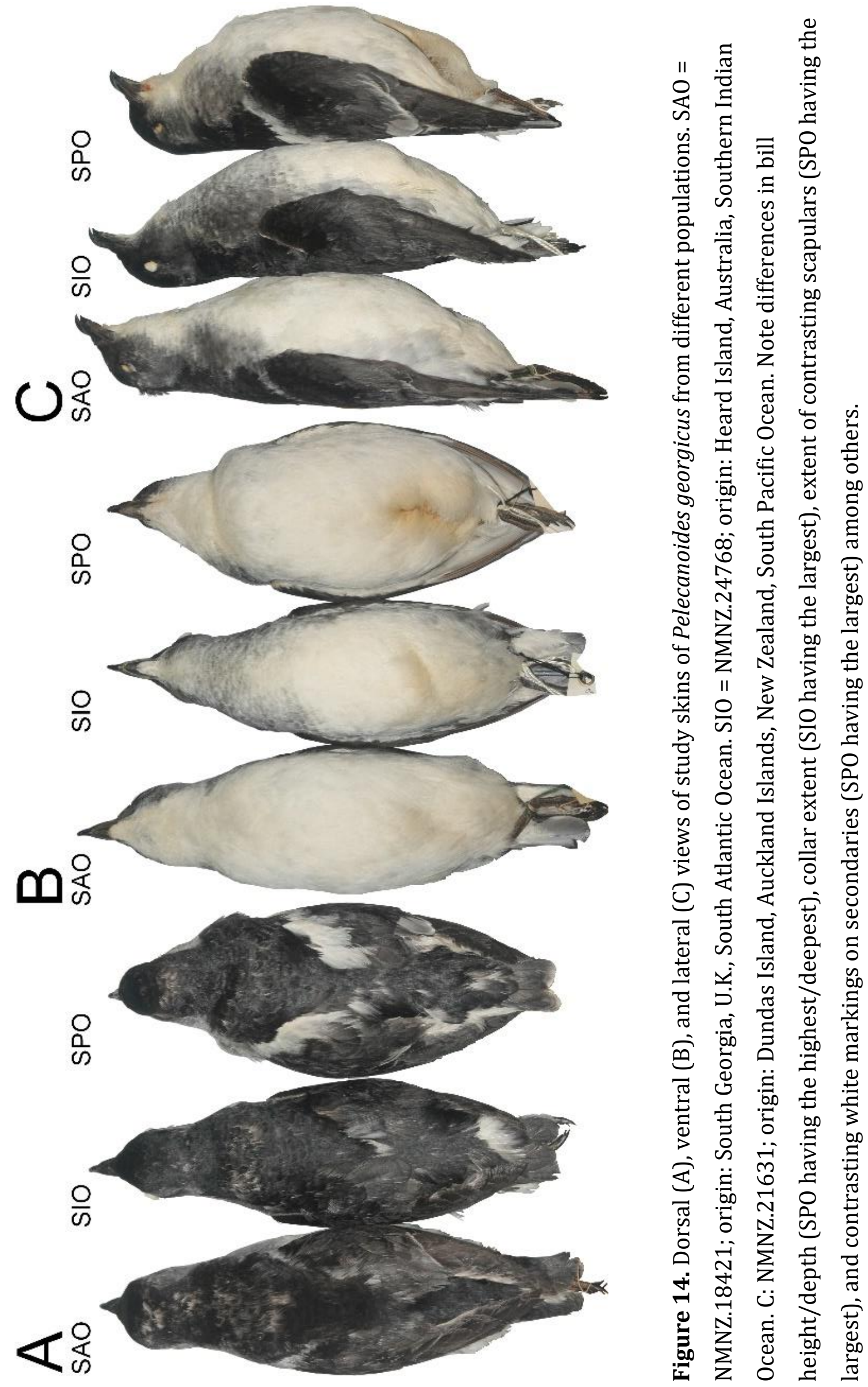

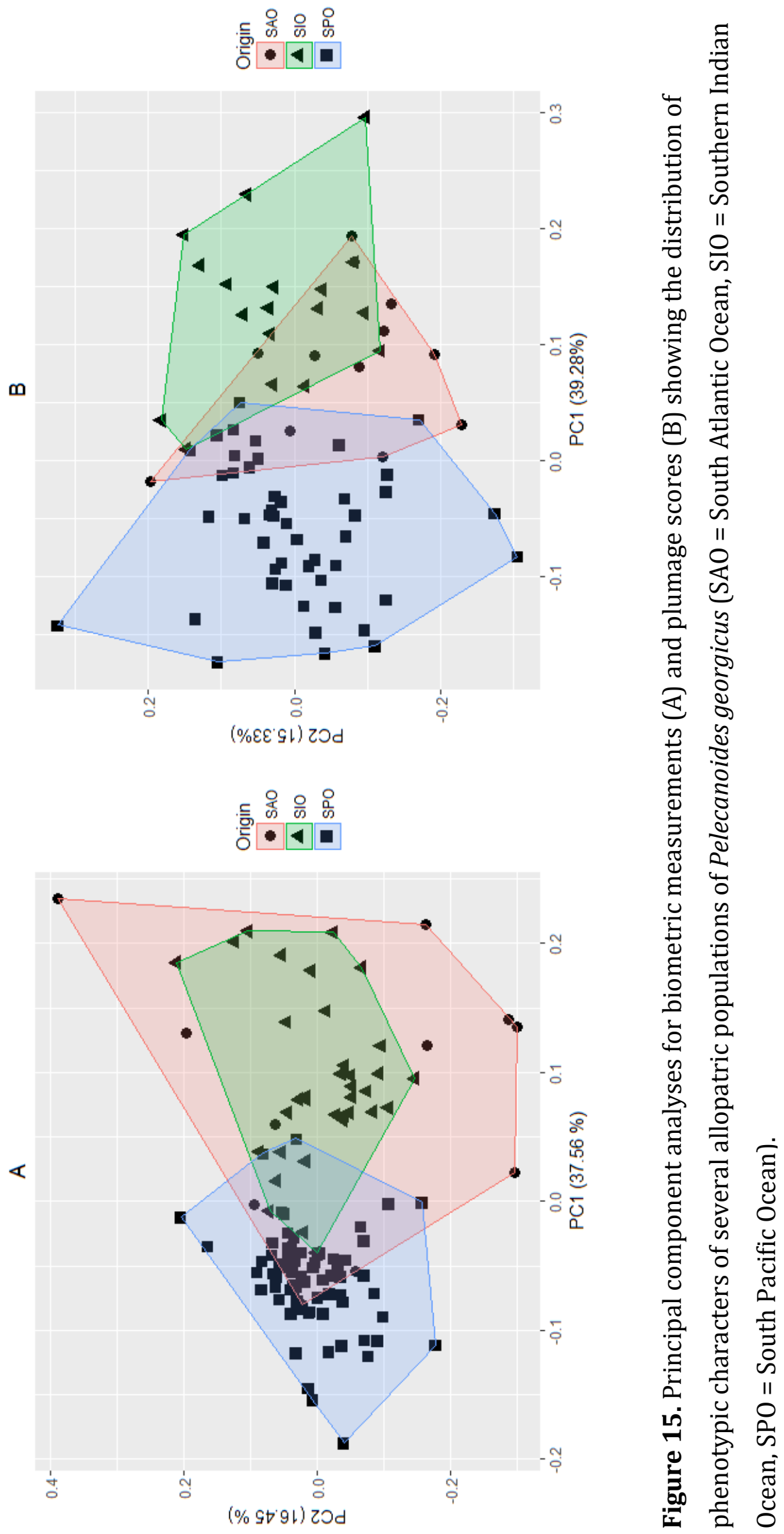
Table 11. Principal component analysis (PCA) loadings on PC1 and PC2 axes for biometric measurements in allopatric Pelecanoides georgicus populations (Figure $15 A)$.

\begin{tabular}{lcr}
\hline Variable & PC1 & PC2 \\
\hline Wing length & -0.450 & 0.128 \\
Length of T6 & -0.423 & -0.285 \\
Length of T1 & -0.396 & 0.110 \\
Tail fork depth & -0.140 & -0.508 \\
Bill length & -0.065 & 0.452 \\
Bill width & -0.106 & -0.516 \\
Bill height & -0.437 & 0.037 \\
Arch length & -0.195 & -0.069 \\
Head length & -0.301 & 0.211 \\
Tarsus length & -0.327 & 0.332 \\
\hline
\end{tabular}

Table 12. Principal component analysis (PCA) loadings on PC1 and PC2 axes for plumage scores in allopatric Pelecanoides georgicus populations (Figure 15B).

\begin{tabular}{lrr}
\hline Variable & PC1 & PC2 \\
\hline Contrasting ear covert extent & 0.195 & -0.608 \\
Collar extent & 0.462 & -0.110 \\
Contrasting scapular extent & -0.379 & -0.328 \\
Contrasting secondary marking extent & -0.425 & -0.182 \\
Contrasting secondary marking shape & -0.256 & 0.287 \\
Contrasting ear covert colour & 0.337 & 0.174 \\
Collar colour & 0.410 & -0.364 \\
Flank colour & 0.275 & 0.481 \\
\hline
\end{tabular}




\section{Plumage characters}

Results of Kruskal-Wallis rank sum tests revealed differences in collar extent $\left(\chi^{2}=\right.$ 43.685, $p<0.001)$, extent of contrasting scapulars $\left(\chi^{2} 2_{2}=30.993, p<0.001\right)$, extent of secondary markings $\left(\chi^{2}{ }^{2}=41.157, p<0.001\right)$, shape of secondary markings $\left(\chi^{2}{ }^{2}=\right.$ $56.870, p<0.001)$, ear-covert colour $\left(\chi^{2} 2=18.400, p<0.001\right)$, collar colour $\left(\chi^{2}{ }^{2}=\right.$ 11.223, $p=0.004)$ and flank colour $\left(\chi^{2} 2=12.094, p=0.002\right)$. Results of pairwise comparisons with Welch's two-sample t-tests with Bonferroni corrections showed that all three pools can be readily distinguished from each other (Table 12 \& Figure 14). Results from a PCA revealed that there is limited overlap between the SAO population and the SIO population as well as between the SAO population and the SPO population and very limited overlap between the SIO population and the SPO population (Table 14 \& Figure 15B).

\section{Phenotypic species delimitation test}

The SAO population differed from the SIO population only in plumage characters: collar extent (reasonably prominent in SAO, while extensive in SIO; score =2) and the shape of contrasting secondary markings (present on both inner and outer vane in SIO and limited to inner vane in SAO; score =1). The SPO population differed from the SAO population through: longer wings $(d=1.380$; score $=1)$, a longer T6 $(d=0.771$; score $=1)$, deeper bills $(d=2.324$; score $=2)$, longer heads $(d=1.340$; score $=1)$ and longer tarsi $(d=1.289$; score $=1)$. Plumage scores when comparing the SPO population to the SAO population were the following: collar extent (very limited in SPO, while reasonably prominent in SAO; score $=2$ ), contrasting scapulars extent (very prominent in SPO, while limited in SAO; score $=2$ ), contrasting secondary marking extent (large and prominent in SPO, while limited in SAO; score = 1), shape of contrasting secondary markings (present on both inner and outer vane in SPO and limited to inner vane in SAO; score $=1$ ). The SPO population differed from the SIO population through: longer wings $(d=1.566$; score $=1)$, a longer T6 $(d=1.756$; score $=1)$ and T1 $(d=1.391$; score $=1)$, deeper bills $(d=1.453$; score $=1)$, longer heads $(d$ $=1.087$; score $=1)$ and longer tarsi $(d=1.099$; score $=1)$. Plumage scores when comparing SPO to SIO were the following: collar extent (very limited in SPO, while extensive in SIO; score = 3), contrasting scapulars extent (very prominent in SPO, while limited in SIO, score $=2$ ), contrasting secondary marking extent (large and 
prominent in SPO, while limited in SIO; score = 1), ear covert colour (light grey in SPO, while grey in SIO; score = 1) and flank colour (light grey in SPO, while grey in SIO; score $=1$ ). In addition, one behavioural/ecological character was scored. The SPO population specialises in breeding in foredunes at sea level (Chapter 3), while the SIO and SAO populations breeds in scree and scoria at high altitudes (Payne \& Prince 1979, Marchant \& Higgins 1990; score = 1). When summing the scores of the phenotypic species delimitation test, the SAO and the SIO population both scored a maximum of 3, while the SPO population scored a maximum of 9.

\section{DISCUSSION}

The SPO P. georgicus population is distinct from both the SAO and SIO populations and exhibits both biometric and plumage characters that are (at least in combination) diagnostic. The SAO population is very similar to the SIO population with only limited differentiation in plumage characters. Results of the quantitative phenotypic species delimitation test showed that the SPO population warrants species status (Tobias et al. 2010). Neither the SAO nor the SIO populations merit species status.

Despite providing evidence for the distinctiveness of the SPO P. georgicus population, this analysis of differences between $P$. georgicus populations is not exhaustive yet. I have not included bioacoustics, nor osteological characters, nor moulting strategies in my analysis. Results of a preliminary bioacoustic analysis indicate considerable differences, at least between the SIO and SPO populations (calls from birds from South Georgia and the Crozet Islands are audibly coarser than calls from birds from Codfish Island; Payne \& Prince 1979, Fischer unpub. data). An extensive bioacoustic analysis may provide further insights on the differentiation of the SPO population and differences between the SIO and SAO populations. Furthermore, an analysis of moulting strategies between the three populations could be informative, for different moulting strategies can also provide clues on the species status of cryptic taxa (Robb et al. 2008).

My results indicate that $P$. georgicus from the SPO is a distinct species, but biometric and plumage characters overlap between P. georgicus populations. All species within Pelecanoides are very similar in both biometrics and plumage 
(Bretagnolle 1993, Onley \& Scofield 2007) and thus, the documented amount of overlap in biometric and plumage characters was to be expected.

An assessment of the specimens from Macquarie Island would be most valuable. Mathews hypothesised in 1935 that an undescribed taxon was present on Macquarie Island and proposed to name it P. georgicus novus (Gill et al. 2010). The extinct Macquarie Island colony (Marchant \& Higgins 1990) was likely an easternmost outlier of the SIO population, as Macquarie Island is devoid of sand dunes. On the other hand, the Macquarie Island colony may have been a westernmost outlier of the SPO population. Alternatively, Macquarie Island hosted yet another undescribed taxon within the P. georgicus complex.

Even though several species have been described based on solely phenotypic characters (e.g., van Balen et al. 2011, Sangster et al. 2013, Eaton \& Collar 2015, Sangster et al. 2016), a thorough molecular analysis of P. georgicus would provide useful insights. Such an analysis would provide further information on the status of the SIO and SAO populations and would also complement the preliminary results by Paterson et al. (2000). Moreover, I suggest such investigations to extend beyond the P. georgicus complex and include the Common Diving Petrel (P. urinatrix) complex or even all Pelecanoides species.

Despite the various shortcomings of the analysis presented here, the SPO population warrants species status based on the criteria of diagnosability and degree of differentiation. Diagnosability was the most frequently applied species criterion in a review of species criteria in avian taxonomy studies (Sangster 2014). The SPO population of P. georgicus exhibits eight phenotypic characters that are, at least in combination, diagnostic. The second most commonly applied criterion was the degree of differences (Sangster 2014). The results of the phenotypic species delimitation test (Tobias et al. 2010) suggest that the SPO population of P. georgicus differs too much from other populations to be treated as subspecies. Other criteria frequently applied in avian taxonomic studies include different adaptive zones and monophyly (Sangster et al. 2014). The SPO populations may qualify as a distinct species under these criteria as well. Differences in breeding habitat may indicate that the SPO population occupies a niche different to the other P. georgicus populations (Marchant \& Higgins 1990, Chapter 3). In addition, the preliminary molecular analysis by Paterson et al. (2000) illustrated that the SPO population has been separated from other P. georgicus 
populations for several 100,000 years. Given the common use of diagnosability and degree of difference as species criterion (Sangster 2014) and the recent broad and international coverage of the applied phenotypic species delimitation test (Tobias et al. 2014) in assessing species limits (del Hoyo et al. 2014, IUCN 2016), I conclude that the SPO P. georgicus population merits species status. I propose to name this species: Pelecanoides taylorii sp. nov.

It should be noted that the following species description should not be seen as a finalised formal description, but as an exercise in taxonomy, part of this thesis.

\section{Diagnosis}

P. taylorii differs from both P. georgicus populations in the SAO and SIO through: 1) longer wings, 2) longer outermost tail feathers, 3) longer heads, 4) longer tarsi and 5) higher (deeper) bills. In addition, P. taylorii differs from the SIO P. georgicus population in having longer innermost tail feathers (Table 12 \& Figure 14).

The biometric differentiation of $P$. taylorii may be indicative of different ecological or behavioural traits of this taxon. For example, wing length is often related to travel distances to and from foraging areas (Shaffer et al. 2001) and foraging behaviour (Hertel \& Balance 1999). Therefore P. taylorii may travel further during breeding seasons or migrate farther non-breeding seasons than the SAO and SIO populations of P. georgicus. In addition, bill morphology is often adapted to feeding ecology (Imber 1981). The different bill height of $P$. taylorii may be linked to different foraging strategies or prey species. Furthermore, tarsus length may be related to burrowing behaviour, as diving petrels (Pelecanoides ssp.) dig their burrows using their legs. P. taylorii on Codfish Island have comparatively long burrows (up to $2 \mathrm{~m}$ deep), while P. georgicus on Crozet Island have comparatively short burrows $(\bar{x}=0.8$ m; Marchant \& Higgins 1990). Alternatively, tarsus length may be related to swimming behaviour (Marchant \& Higgins 1990).

P. taylorii differs from P. georgicus of both SAO and SIO populations through several well developed and more contrasting plumage characters: 1) the very limited collar that is only visible on the breast sides, 2) well defined and prominent, contrasting white scapulars and, 3) large contrasting white markings on secondaries. 
In addition, $P$. taylorii differs from the SAO P. georgicus through contrasting markings on both inner and outer vanes of the secondaries. Furthermore, P. taylorii differs from SIO P. georgicus through lighter grey ear coverts and flanks (Table 12 Figure 14).

The different plumage traits of $P$. taylorii may be indicative of different life history traits. Procellariiformes with paler plumages forage in colder waters at higher latitudes (Bretagnolle 1993). Therefore, it is likely that the contrasting, pale plumage characters, diagnostic of $P$. taylorii, have developed due to more southerly foraging areas than P. georgicus. Furthermore, plumage colouration may also be related to high inshore predation pressure, which potentially drives crypsis in small Procellariiformes (Bretagnolle 1993). The more conspicuous P. taylorii may thus feed further off shore than the duller P. georgicus.

\section{Generic placement}

P. taylorii clearly belongs in Pelecanoides, Lacepédè 1799, (family: Pelecanoididae, order: Procellariiformes) rather than any other genus within Procellariiformes based on a combination of short, paddle-like wings, short tail, small and compact build and bill morphology (short, broad based bill with hooked tip and throat pouch) (Onley \& Scofield 2007, Gill et al. 2010).

\section{Etymology}

The scientific name honours GA Taylor, one of New Zealand's leading seabird scientist, who dedicates his life to the preservation of New Zealand's seabird diversity (e.g., Taylor 2000) and is actively involved in the conservation of the New Zealand Storm Petrel (Paeleornis maoriana; e.g., Rayner et al. 2015), Chatham Petrel (Pteroroma axillaris; e.g., Gummer et al. 2015), Chatham Island Taiko (Pterodroma magentae; e.g., Taylor et al. 2012) and P. taylorii (e.g., Taylor \& Cole 2002, Taylor 2013) among many others. I propose the following common species name: Dunehaunter. This name refers to the distinct preference exhibited by this species for breeding in coastal dune systems, as well as the nocturnal habits of the species. 


\section{Holotype}

NMNZ.21631 (adult female), collected at Dundas Island, Auckland Islands, New Zealand, on 28 October 1943 by RA Falla (Figure 14). Previously assigned to $P$. georgicus.

\section{Paratypes}

The following 11 specimens were all previously assigned to P. georgicus and used in the species description of P. taylorii: BMNH.1842.12.16.41 (sex and age unknown), collected at Enderby Island, Auckland Islands, New Zealand, by RA Falla. NMNZ.21057 (adult male) and NMNZ.21058 (adult female), both collected at Codfish Island, New Zealand, on 22 September 1978 by MJ Imber. NMNZ.21070 (female) and NMNZ.21071 (adult female), both collected at Codfish Island, New Zealand, on 17 November 1978 by PC Harper. NMNZ.27537 (adult male), NMNZ.27538 (adult male), NMNZ.27539 (adult female), NMNZ.27540 (adult female) and NMNZ.27541 (adult male), all collected at Codfish Island, New Zealand, in September/October 2003 by the New Zealand Department of Conservation (DOC).

\section{Description of the holotype}

HEAD: the forehead and crown are glossy black. The nape is glossy black, but feather bases are light grey. The lores are black. The cheeks and ear coverts are mottled and light grey, creating a prominent and contrasting pattern. A small dark grey patch above the eye gives the appearance of a restricted brow/supercilium (Figure 14AC).

UPPERPARTS: The mantle feathers have light grey bases and glossy black tips. The scapulars are pure white, prominent, contrasting and almost connected above the rump. The rump and back are glossy black, but feather bases are white. The uppertail coverts have broad white bases and glossy black tips (Figure 14A).

UNDERPARTS: The chin, throat and upper breast are dirty white, while the lower breast, belly and undertail coverts are pure white. The breast and neck sides are mottled light grey, resulting in a small collar. The flanks are smudged light grey (Figure 14B).

WING: The upperwing coverts (both primary and secondary) and tertails are glossy black with a brown hue and glossy black tips. Dorsally, the primaries are dull black with a brown hue. Ventrally, the primaries have dirty white inner vanes and 
light grey outer vanes. The third outermost primaries are the longest. The secondaries are dull black on the outer vane dorsally and dark grey ventrally, while the inner vane is light grey (both dorsally and ventrally). The secondaries have broad white tips extending towards the base on both inner and outer vanes. The secondary feather tips are fringed outwards. The underwing coverts (both primary and secondary) are pure white, while the axillaries are light grey (Figure 14 AC).

TAIL: The retrices are dull black dorsally and dark grey ventrally, apart from the outermost pair, which is light grey on the inner vane. The two outer retrices (T6 \& T5) are longer than the inner retrices (T4-T1; T1 being the shortest), resulting in a shallow tail fork (Figure 14A).

BARE PARTS: the bill is black, with a hooked tip, a broad base and convergent bill sides. The lower mandible arch is pointed and sides are dull brown, suggesting a faded colour (live birds have sky blue lower mandible arch sides). The nostrils (nasal tubes) are black, parallel and facing upwards with a medial paraseptal process. The gular pouch is dark grey. The legs and webbed feet are dull brown, suggesting a faded colour (live birds have cobalt blue legs), with a hint of a black line on the back of the tarsus. The claws are black and flattened.

\section{Variation in type series}

NMNZ.21058 (adult female) differs from holotype through: 1) a black brow, and 2) grey outer retrices. NMNZ.21070 (female) differs from holotype through: 1) a black brow, 2) black cheeks, 3) grey ear coverts, 4) small contrasting ear patch extent, and 5) small extent of contrasting white scapulars. NMNZ.21071 (adult female) differs from holotype through: 1) a black brow, 2) grey ear coverts, and 3) a more prominent collar. NMNZ.27539 (adult female) differs from holotype through: 1) grey ear coverts, 2) black cheeks, and 3) pure white flanks. NMNZ.27540 (adult female) differs from the holotype through: 1) a black brow, 2) black cheeks, 3) grey ear coverts, 4) grey outer retrices, 5) pure white flanks, and 6) small amount contrasting white markings on secondaries.

NMNZ.21057 (adult male) differs from holotype through: 1) a black brow, and 2) grey ear coverts. NMNZ.27537 (adult male) differs from holotype through: 1) a black brow, 2) black cheeks, 3) grey ear coverts, and 4) a more prominent collar. NMNZ.27538 (adult male) differs from holotype through: 1) pure white flanks, and 2) 
black cheeks. NMNZ.27541 (adult male) differs from holotype through: 1) a black brow, 2) black cheeks, 3) grey ear coverts, 4) a more prominent collar, and 5) grey outer retrices.

BMNH.1842.12.16.41 (sex unknown) differs from holotype through: 1) a black brow, 2) grey ear coverts, and 3) a more extensive grey collar.

\section{Identification at sea}

Diving Petrels are notoriously difficult to identify at sea (Onley \& Scofield 2007). For example, distinguishing P. urinatrix from P. georgicus is close to impossible, unless very clear photographs are obtained. Even high resolution photographs are unlikely to clearly depict the subtle differences between P. georgicus and P. taylorii. As it is currently unknown whether ranges overlap, albeit unlikely, it appears impossible to positively identify P. taylorii at sea.

\section{Distribution}

All known specimens of $P$. taylorii originate from either Dundas Island, Enderby Island (Auckland islands, New Zealand), or Codfish Island, New Zealand (Figure 1). P. taylorii remains extant only on Codfish Island only, where it breeds in a minute (20 x $900 \mathrm{~m})$ strip of coastal sand dunes in the Sealers Bay (Chapter $3 \& 4$ ). The historic distribution of P. taylorii in New Zealand encompassed the Otago Peninsula on the South Island, Mason's Bay on Stewart Island, Enderby and Dundas Islands on the Auckland Islands and Chatham Islands (Worthy 1998, Taylor 2000, Holdaway et al. 2003, Wood \& Briden 2008). The historic presence of $P$. taylorii on Macquarie Island remains uncertain. The offshore distribution of $P$. taylorii also remains unknown. Some evidence indicates that the species forages on the edge of the continental shelf during the breeding season (Imber \& Nilsson 1980). Future studies investigating offshore distribution during breeding and non-breeding season of P. taylorii (and P. georgicus from the SAO and SIO populations) are encouraged.

\section{Habitat \& biology}

P. taylorii breeds in long burrows in coastal sand dunes. It prefers foredunes (0-20 meter from spring tide line) with steep, seaward-facing slopes, high sand flux and 5080\% plant cover (Chapter 3). P. taylorii appears to be tolerant to the current suite of 
invasive plants at Codfish Island. P. taylorii presumably returns to Codfish Island from its unknown wintering grounds in October (Taylor 2013). Eggs hatch in late November. Chicks fledge in mid to late January (Taylor 2013, Fischer unpub. data). Nocturnal change-over rates of adults are approximately four days during incubation and one day during chick rearing (Taylor \& Cole 2002, Taylor 2013, Fischer unpub. data). Information on prey items remains equally anecdotal, with two specimens having eusphausiids, small fish and small squids in their stomachs (Imber \& Nilsson 1980).

\section{Conservation implications}

P. georgicus is currently considered Least Concern by the IUCN (2016). The proposed split of $P$. georgicus would not change the conservation status for the SAO and SIO $P$. georgicus populations. Both still number in the millions, both have a large range, and there are no indications of any current population declines (Marchant \& Higgins 1990, Brooke 2004).

However, $P$. taylorii is at extremely high risk of extinction. The range of $P$. taylorii has decreased dramatically in the past and the species has been extirpated throughout its range, most likely due to introduced predators (Worthy 1998, Taylor 2000, Holdaway et al. 2003, Wood \& Briden 2008). P. taylorii is now restricted to Codfish Island and the population size is estimated at 150 adults (Taylor 2013). The DOC therefore, considers this taxon Nationally Critical (Robertson et al. 2013). Therefore, I propose to list P. taylorii as Critically Endangered on the IUCN Red List. When applying the IUCN (2012) criteria to P. taylorii, it qualifies for listing as Critically Endangered, based on criteria B2ab (ii, iii) and C2a (ii). P. taylorii has an extremely limited area of occupancy during the breeding season (20 x $900 \mathrm{~m})$ at only a single location. Its habitat is degrading due to storms and storm surges, which reduce the area of occupancy (Taylor \& Cole 2002, Cole 2004, Chapter 3). Furthermore, the estimated population size is very small (approx. 150 adults; Taylor 2013), all individuals are part of this one population and a decline is expected due to the impact of storms and storm surges during breeding seasons (Chapter 3). Moreover, competition with P. urinatrix for nest sites may be a minor threat to P. taylorii (Chapter 4). Critically Endangered is indicative of an extremely high risk of extinction 
(IUCN 2012), and thus underlines the need of conservation prioritization for $P$. taylorii.

\section{CONCLUSION}

Here, I provide evidence of the distinctiveness of the Dunehaunter (Pelecanoides taylorii sp. nov.; previously part of the South Georgian Diving Petrel P. georgicus complex), which is a Critically Endangered taxon. The conservation status of this species has remained "hidden" to global conservation panels due to the inclusion in a polytypic "species". New Zealand maintains a national threat classification system (Robertson et al. 2013) and therefore, the dire situation of the P. taylorii has been acknowledged within New Zealand. Consequently, national threat classification systems that complement global threat classification systems should be advocated, as they may classify and protect taxa for which the taxonomy is still unclear. In addition, taxonomists are advised to focus on polytypic species that are likely to include threatened taxa (Sangster et al. 2016), for conservation efforts depend on species being a clear and single ecological unit. 
Chapter 6 


\section{Chapter 6.}

\section{GENERAL CONCLUSION}

I

N CHAPTER 2, I illustrated that small Procellariiformes in New Zealand are most often threatened onshore by invasive predators, but additional other terrestrial threats exist, which can fall under both the small and the declining population paradigm (Caughley 1994). This predicament is illustrated by the New Zealand population of the South Georgian Diving Petrel (Pelecanoides georgicus; SGDP). In Chapter 5, I provided evidence granting this population species status, based on the criteria of diagnosability and degree of difference (Sangster 2014). In Chapter 3, I demonstrated that this potential Codfish Island (Whenua Hou) endemic is under considerable threat from stochastic events, such as storms, causing erosion of the preferred breeding habitat (i.e. fragile foredunes). Moreover, in Chapter 4, I argued that competition for nest-sites with the Common Diving Petrel (P. urinatrix; CDP) may form a minor additional risk for this SGDP population.

To effectively address the small population paradigm in the SGDP in New Zealand, a translocation might be considered to conserve this highly-threatened population. This population depends on steep, seaward-facing foredunes with mobile soils for breeding (Chapter 3) and evidence suggests that stochastic events, such as storms and storm surges, will continue to threaten the its colony during the breeding season by eroding these foredunes (Cole 2004, Blair 2007, Hennessy et al. 2007). Based on these results, I conclude that environmental stochasticity is the most pressing known threat to this species, which falls under the small population paradigm (Caughley 1994). Yet any investment in storm protection (e.g., a storm wall) is unlikely to result in a population increase, as the distinct preference of this species for fragile foredunes may not change. A translocation however, may render this species less vulnerable to stochastic events and catastrophes, enable SGDPs to recolonize other areas of their historic distribution in New Zealand, and allow the SGDP population to increase. In addition, recolonizing New Zealand's dune systems with SGDPs would reinstate historic dune ecosystem functioning. 
Procellariiformes tend not to recolonize extirpated colonies due to their high philopatry (Miskelly et al. 2009). Therefore, translocations are a common tool to restore lost colonies and render Procellariiform species less vulnerable (Miskelly \& Taylor 2004, Miskelly et al. 2009). However, seabird translocation techniques depend on detailed information on breeding biology and activity, as pre-fledging chicks are used in translocations and thus, techniques need to be tailored to mimic the natural breeding biology of the target species (Miskelly \& Taylor 2004, Miskelly et al. 2009). Methods developed to translocate CDPs could form a guideline for a SGDP translocation (Miskelly \& Taylor 2004). Yet, ideally data from the target species should be used to design translocation strategies. Non-invasive methods used to study the breeding biology and activity patterns of the SGDP on Codfish Island proved to be suboptimal (Chapter 4). Consequently, the placement of study burrows should be considered to study the breeding biology of the species more in-depth and thus provide the data necessary to structure a future translocation.

The population of the SGDP is extremely small (approx. 150 individuals; Taylor $2000,2013)$, a translocation of this species has never been attempted and consequently, the development of a species-specific population dynamics model using data from the Codfish Island population is advisable. This would allow for future SGDP translocations to be tested in a theoretical framework. A population modelling approach would enable for a translocation to be planned and structured while minimizing the impact on the source population in the long-term (Armstrong \& McLean 1995). It seems advisable to include effects from environmental stochasticity and catastrophes into such models (Armstrong \& Reynolds 2012), due to the susceptibility of the species to storms during the breeding season (Chapter 3). Furthermore, the CDP population within the SGDP colony on Codfish Island should be further monitored and its long-term impact on the species quantified (Chapter 4). A competition parameter could then also be included in the population dynamics model to further assess SGDP (and CDP) population trends. Finally, a trial translocation within Codfish Island would allow for assessment of the potential success rate and thus further fine-tuning of the population dynamics model and SGDP translocation techniques. Only after these necessary steps, it seems advisable to attempt a translocation of this species to other islands and thus, mitigate the current risks of the 
small population paradigm to the New Zealand population of the South Georgian Diving Petrel on Codfish Island. 


\section{REFERENCES}

Abraham ER \& Thompson FN. 2011. Summary of the capture of seabirds, marine mammals, and turtles in New Zealand commercial fisheries, 1998-99 to 200809. New Zealand Aquatic Environment and Biodiversity Report No. 80. Ministry of Fisheries, Wellington, New Zealand.

Abraham ER, Thompson FN \& Berkenbusch K. 2013. Estimated capture of seabirds in New Zealand trawl and longline fisheries, 2002-03 to 2010-11. Final Research Report for Ministry for Primary Industries project PR02010-01. Ministry of Primary Industries, Wellington, New Zealand.

Alström P, Rasmussen PC, Zhao C, Xu J, Dalvi S, Cai T, Guan Y, Zhang R, Kalyakin MV, Lei F \& Olsson U. 2016. Integrative taxonomy of the Plain-backed Thrush (Zoothera mollimissima) complex (Aves, Turdidae), reveals cryptic species, including a new species. Avian Research 7: 1-39.

Alström P, Xia C, Rasmussen PC, Olsson U, Dai B, Zhao J, Leader PJ Carey GJ, Dong Y, Cia T, Holt P, Manh HL Song G, Liu Y, Zhang Y \& Lei F. 2015. Integrative taxonomy of the Russet Bush Warbler Locustella mandelli complex reveals a new species from central China. Avian Research 6: 1-33.

Armstrong DP \& McLean IG. 1995. New Zealand translocations: theory and practice. Pacific Conservation Biology 2: 39 - 54.

Armstrong DP \& Reynolds MH. 2012. Modelling reintroduced populations: The state of the art and future directions. In: Ewen JG, Armstrong DP, Parker KA \& Seddon PJ (eds.). Reintroduction Biology. John Wiley \& Sons Ltd., Oxford, U.K.

van Balen S, Eaton JA, Rheindt FE. 2011, Biology, taxonomy and conservation of the Short-tailed Green Magpie Cissa [t.] thalassina from Java. Bird Conservation International 23: 91-109.

Bartoń K. 2016. MuMIn: R package for model selection and multi-model inference (version 1.15.6). https://CRAN.R-project.org/package=MuMIn.

Beers TW, Dress PE \& Wensel LC. 1966. Aspect transformation in site productivity research. Journal of Forestry 64: 691-692. 
Bell BD, Daugherty CH, Hitchmough RA. 1998. The taxonomic identity of a population of terrestrial Leiopelma (Anura: Leiopelmatidae) recently discovered in the northern King Country, New Zealand. New Zealand Journal of Zoology 25: 139146.

Bell M, Bell BD \& Bell EA. 2005. Translocation of Fluttering Shearwater (Puffinus gavia) chicks to create a new colony. Notornis 52: 11-15.

Black A. 2005. Light induced seabird mortality on vessels operating in the Southern Ocean: incidents and mitigating measures. Antarctic Science 17: 67-68.

Blackmer AL, Ackerman JT \& Nevitt GA. 2004. Effects of investigator disturbance on hatching success and nest-site fidelity in a long-lived seabird, Leach's Storm Petrel. Biological Conservation 116: 141-148.

Blair F. 2007. How vulnerable is New Zealand to the impacts of climate change? New Zealand Geographer 63: 160-168.

Bretagnolle V. 1993. Adaptive significance of seabird coloration: the case of Procellariiforms. The American Naturalist. 142: 141-173.

Brooke M. 2004. Albatrosses and petrels across the world. Oxford University Press, Oxford, U.K.

Brooks TM, Mittermeier RA, da Fonseca GAB, Gerlach J, Hoffmann M, Lamoreux JF, Mittermeier CG, Pilgrim JD \& Rodrigues ASL. 2006. Global biodiversity conservation priorities. Science 313: 58-61.

Burnham KP \& Anderson DA. 2002. Model selection and multi-model inference: a practical information-theoretic approach. Springer, New York, U.S.A.

Bushnell Outdoor Technology. 2011. Bushnell Trophy Cam ${ }^{\mathrm{TM}}$ instruction manual (model \#s: 119436/119446/119456). Bushnell Outdoor Products, Kansas, U.S.A.

Butchart SHM, Stattersfield AJ, Bennun LA, Shutes SM, Akçakaya RH, Baillie JEM, Stuart SN, Hilton-Taylor C \& Mace GM. 2004. Measuring global trends in the status of biodiversity: Red list indices for birds. PloS Biology e383. DOI: http://dx.doi.org/10.1371/journal.pbio.0020383.

Buxton RT, Anderson D, Moller H, Jones CJ \& Lyver PO. 2015. Release of constraints on nest-site selection in burrow-nesting petrels following invasive rat eradication. Biological Invasions 17: 1453-1470. 
Buxton RT, Currey CA, Lyver PO \& Jones CJ. 2013. Incidence of plastic fragments among burrow-nesting seabird colonies on offshore islands in northern New Zealand. Marine Pollution Bulletin 74: 420-424.

Cassini MH. 2013. Distribution ecology: From individual habitat use to species biogeographical range. Springer, New York, U.S.A.

Caughley G. 1994. Directions in conservation biology. Journal of Animal Ecology 63: $215-244$

Cheke A \& Hume PJ. 2010. Lost land of the Dodo: the ecological history of Mauritius, Réunion and Rodrigues. Bloomsbury Publishing, London, U.K.

Chu S, Wang J, Leong G, Lee A, Letcher RJ \& Li QX. 2015. Perfluoroalkyl sulfonates and carboxylic acids in liver, muscle and adipose tissues of Black-footed Albatross (Phoebastria nigripes) from Midway Island, North Pacific Ocean. Chemosphere 138: 60-66.

Cieraad E, Walker S, Price R \& Barringer J. 2015. An updated assessment of indigenous cover remaining and legal protection in New Zealand's land environments. New Zealand Journal of Ecology 39: 309-315.

Cohen LB \& Dearborn DC. 2004. Great Frigatebirds, Fregata minor, choose mates that are genetically similar. Animal behaviour 68: 1229-1236.

Cole R. 2004. Summary of South Georgian Diving Petrel field observations for 2003/04, Codfish Island/Whenua Hou. Department of Conservation, Invercargill, New Zealand.

Collar NJ \& Marsden SJ. 2014. The subspecies of Yellow-crested Cockatoo Cacatua sulphurea. Forktail 30: 23-27.

Croxall JP, Butchart SHM, Lascelles B, Stattersfield AJ, Sullivan B, Symes A \& Taylor P. 2012. Seabird conservation status, threats and priority actions: a global assessment. Bird Conservation International 22: 1-34.

Diamond J. 1984. "Normal” extinctions of isolated populations. In: Nitecki MH (ed.). Extinctions. University of Chicago Press, Chicago, U.S.A.

Dilley BJ, Davies D, Bond AL \& Ryan PG. 2015. Effects of mouse predation on burrowing petrel chicks at Gough Island. Antarctic Science 27: 543-553.

Domencich TA \& McFadden D. 1975. Urban travel demand- a behavioural analysis. North-Holland Publishing, Oxford, U.K. 
Duncan RP \& Blackburn TM. 2004. Extinctions and endemism in the New Zealand avifauna. Global Ecology and Biogeography 13: 509-517.

Eaton JA \& Collar NJ. 2015. The taxonomic status of Pycnonotus bimaculatus snouckaerti. Forktail 31: 107-110.

Entwistle A \& Dunstone N. 2000. Priorities for conservation of mammalian diversity: has the panda had its day? (Vol. 3). Cambridge University Press, Cambridge, U.K.

Falla RA. 1960. Oceanic birds as dispersal agents. Proceedings of the Royal Society of London. Series B, Biological Sciences 152: 655-659.

Farrimond M, Elliott GP \& Clout MN. 2006. Growth and fledging of Kakapo. Notornis 53: $112-115$.

Fernandez-Duque E \& Claudia Vallegia C. 2010. Meta-analysis: a valuable tool in conservation research. Conservation Biology 8: 555-561.

Fraser M, Henderson G, Robertson CJR \& Scofield P. 2011. Population dynamics of the Chatham Mollymawk at The Pyramid, 19 November - 2 December 2010. Ministry of Primary Industries, Wellington, New Zealand.

French K. 2012. Competition strength of two significant invasive species in coastal dunes. Plant Ecology 213: 1667-1673.

Friesen MR, James RR, Mainland M \& Gaskin CP. 2016. First record of a petrel species killed by penguins: outcome of competition for artificial nesting boxes. Notornis 63: $112-115$

Fry DM, Fefer SI \& Sileo L. 1987. Ingestion of plastic debris by Laysan Albatrosses and Wedge-tailed Shearwaters in the Hawaiian Islands. Marine Pollution Bulletin 18: $339-343$

Furness RW \& Camphuysen CJ. 1997. Seabirds as monitors of the marine environment. ICES Journal of Marine Science 54: 726-737.

Gardner P \& Wilson KJ. 1999. Chatham Petrel (Pterodroma axillaris) studies - breeding biology and burrow blockading. Department of Conservation, Wellington, New Zealand.

Gaze P. 2000. The response of a colony of Sooty Shearwater (Puffinus griseus) and Flesh-footed Shearwater (P. carneipes) to the cessation of harvesting and the eradication of Norway rats (Rattus norvegicus). New Zealand Journal of Zoology 27: 375-379. 
Gill BJ, Bell BD, Chambers BD, Medway DG, Palma RI, Scofield RP, Tennyson AJD \& Worthy TH. 2010. Checklist of the birds of New Zealand, Norfolk and Macquarie Islands, and Ross Dependency, Antarctica (4th edition). Te Papa Press, Wellington, New Zealand.

Griffiths GCD. 1974. On the foundations of biological systematics. Acta Biotheoretica 23: 85-131.

Gummer H, Taylor G, Wilson K-J \& Rayner MJ. 2015. Recovery of the endangered Chatham Petrel (Pterodroma axillaris): A review of conservation management techniques from 1990 to 2010. Global Ecology and Conservation. 3: 310-323.

Harrel FE. 2016. Hmisc Harrel Miscellaneous (version 3.17-4). https://CRAN.Rproject.org $/$ package $=$ Hmisc .

Harris MP. 1980. Post-mortem shrinkage of wing and bill of Puffins. Ringing \& Migration 3: 60-61.

Haw JM \& Clout MN. 1999. Diet of Morepork (Ninox novaeseelandiae) through New Zealand by analysis of stomach contents. Notornis 46: 333-345.

Hawke DJ \& Holdaway RN. 2005. Avian assimilation and dispersal of carbon and nitrogen brought ashore by breeding Westland Petrels (Procellaria westlandica): a stable isotope study. Journal of Zoology 266: 419-426.

Hay JM, Sarre SD, Lambert DM, Allendorf FW \& Daugherty CH. 2010. Genetic diversity and taxonomy: a reassessment of species designation in tuatara (Sphenodon: Reptilia). Conservation Genetics 11: 1063-1081.

Heather BD \& Robertson, HA. 2015. The field guide to the birds of New Zealand. Penguin Random House, Auckland, New Zealand.

Hennessy K, Fitzharris B, Bates BC, Harvey N, Howden M, Hughes L, Salinger J \& Warrick R. 2007. Australia and New Zealand. In: Parry ML, Canziani OF, Palutikof JP, Hanson CE \& van der Linden P (eds.). Climate change 2007: Impacts, adaptation and vulnerability. Contribution of working Group II to the fourth assessment report of the intergovernmental panel on climate Change, Chapter 11, pp. 507-540. Cambridge University Press, Cambridge, U.K.

Hertel F \& Balance LT. 1999. Wing ecomorphology of seabirds from Johnston Atoll. The Condor 101: 549-566.

Hesp PA. 1999. The beach backshore and beyond. In: Short A (ed.). Handbook of beach and shoreface morphodynamics. John Wiley \& Sons Ltd., Chichester, U.K. 
Higham JES. 1998. Tourists and albatrosses: the dynamics of tourism at the Northern Royal Albatross colony, Taiaroa Head, New Zealand. Tourism Management 19: 521-531.

Hirokoshi M \& Tang Y. 2016. ggfortify: Data visualization tools for statistical analysis (version 0.2.0). https://CRAN.R-project.org/package=ggfortify.

Hoffmann M, Hilton-Taylor C, Angulo A, Böhm M, Brooks TM, Butchart SM, Carpenter KE, Chanson J, Collen B, Cox NA, Darwall WRT, Dulvy NK, Harrison LR, Katariya V, Pollock CM, Quader S, Richman NI, Rodrigues ASL, Tognelli MF, Vié J-C, Aguiar JM, Allen DJ, Allen GR, Amori G, Ananjeva NB, Andreone F, Andrew P, Ortiz ALA, Baillie JEM, Baldi R, Bell BD, Biju SD, Bird JP, Black-Decima P, Blanc JJ, Bolaños F, Bolivar-G. W, Burfield IJ, Burton JA, Capper DR, Castro F, Catullo G, Cavanagh RD, Channing A, Chao NL, Chenery AM, Chiozza F, Clausnitzer V, Collar NJ, Collett LC, Collette BB, Fernandez CFC, Craig MT, Crosby MJ, Cumberlidge N, Cuttelod A, Derocher AE, Diesmos AC, Donaldson JS, Duckworth JW, Dutson G, Dutta SK, Emslie RH, Farjon A, Fowler S, Freyhof J, Garshelis DL, Gerlach J, Gower DJ, Grant TD, Hammerson GA, Harris RB, Heaney LR, Hedges SB, Hero J-M, Hughes B, Hussain SA, Icochea JM, Inger RF, Ishii N, Iskandar DT, Jenkins RKB, Kaneko Y, Kottelat M, Kovacs KM, Kuzmin SL, La Marca E, Lamoreux JF, Lau MWN, Lavilla EO, Leus K, Lewison RL, Lichtenstein G, Livingstone SR, Lukoschek V, Mallon DP, McGowan PJK, McIvor A, Moehlman PD, Molur S, Alonso AM, Musick JA, Nowell K, Nussbaum RA, Olech W, Orlov NL, Papenfuss TJ, Parra-Olea G, Perrin WF, Polidoro BA, Pourkazemi M, Racey PA, Ragle JS, Ram M, Rathbun G, Reynolds RP, Rhodin AGJ, Richards SJ, Rodríguez LO, Ron SR, Rondinini C, Rylands AB, de Mitcheson YS, Sanciangco JS, Sanders KL, Santos-Barrera G, Schipper J, SelfSullivan C, Shi Y, Shoemaker A, Short FT, Sillero-Zubiri C, Silvano DL, Smith KG, Smith AT, Snoeks J, Stattersfield AJ, Symes AJ, Taber AB, Talukdar BK, Temple HJ, Timmins R, Tobias JA, Tsytsulina K, Tweddle D, Ubeda C, Valenti SV, van Dijk PP, Veiga LM, Veloso A, Wege DC, Wilkinson M, Williamson EA, Xie R, Young BE, Akçakaya HR, Bennun L, Blackburn TM, Boitani L, Dublin HT, da Fonseca GAB, Gascon C, Lacher TE, Mace GM, Mainka SA, McNeely JA, Mittermeier RA, Reid GM, Rodriguez PJ, Rosenberg AA, Samways MJ, Smart J, Stein BA \& Stuart SN. 2010. The impact of conservation on the status of the world's vertebrates. Science 330: 1503-1509. 
Holdaway RN, Jones MD, \& Athfield NRB. 2003. Establishment and extinction of a population of South Georgian diving petrel (Pelecanoides georgicus) at Mason Bay, Stewart Island, New Zealand, during the late Holocene. Journal of the Royal Society of New Zealand 33: 601-622.

del Hoyo J, Collar NJ, Christie DA, Elliott A \& Fishpool DC. 2014. HBW and BirdLife International Illustrated Checklist of Birds of the World. Volume 1: Nonpasserines. Lynx edicions, Barcelona, Spain.

del Hoyo J, Elliott A, Sargatal J, Christie DA \& de Juana E (eds.). 2015. Handbook of the Birds of the World Alive. Lynx Edicions, Barcelona. (retrieved from http://www.hbw.com/ on 01 August 2015).

Imber MJ \& Nilsson RJ. 1980. South Georgian Diving Petrels (Pelecanoides georgicus) breeding on Codfish Island. Notornis 27: 325 - 330.

Imber MJ. 1981. Diets of storm petrels Pelagodroma and Garrodia and prions Pachyptila (Procellariiformes) ecological separation and bill morphology. In: Cooper J (ed.). Proceedings of the symposium on birds of the sea and shore 1979. African Seabird Group, Cape Town, South Africa.

Ismar, SMH, Baird KA, Gaskin CP, Taylor GA, Tennyson AJD, Rayner MJ, Bettesworth D, Fitzgerald N, Landers TJ \& Imber MJ. 2014. A case of natural recovery after the removal of invasive predators - community assemblage changes in the avifauna of Burgess Island. Notornis 61: 188-195.

IUCN. 2012. IUCN Red List categories and criteria: Version 3.1. Second edition. Gland, Switzerland and Cambridge, U.K.

IUCN. 2016. IUCN Red list of threatened species. Version 2016.2. www.iucnredlist.org. Downloaded 06 September 2016.

Johnson DH. 1980. The comparison of usage and availability measurements for evaluating resource preference. Ecology 61:65-71.

Johnston RB, Bettany SM, Ogle RM, Aikman HA, Taylor GA \& Imber MJ. 2003. Breeding and fledging behaviour of the Chatham Taiko (Magenta Petrel) Pterodroma magentae and predator activity at burrows. Marine Ornithology 31: 193-197.

Jones HP, Holmes, ND, Butchart SHM, Tershy BR, Kappes PJ, Corkery I, Aguirre-Munoz A, Armstrong DP, Bonnaud E, Burbidge AA, Campbell K, Courchamp F, Cowan PE, Cuthbert RJ, Ebbert S, Genovesi P, Howald GR, Keitt BS, Kress SW, Miskelly CM, Oppel S, Poncet S, Rauzon MJ, Rocamora G, Russel JC, Samaniego-Herrera A, 
Seddon PJ, Spatz DR, Towns DR. \& Croll DA. 2016. Invasive mammal eradication on island results in substantial conservation gains. Proceedings of the National Academy of Science of the United States of America 113: 4033-4038.

Jones HP, Tershy BR, Zavaleta ES, Croll DA, Keitt BS, Finkelstein ME \& Howald GR. 2007. Severity of the effects of invasive rats on seabirds: A global review. Conservation Biology 22: 16-26.

Kays RW \& Slauson KM. 2008. Remote Cameras. In: Long RA, MacKay P, Zielinski WJ \& Ray JC (eds.). Noninvasive survey methods for carnivores. Island Press, London, U.K.

Keitt BS, Wilcox C, Tershy BR, Croll DA \& Donlan CJ. 2002. The effect of feral cats on the population viability of Black-vented Shearwaters (Puffinus opisthomelas) on Natividad Island, Mexico. Animal Conservation 5: 217-223.

Kinsky FC \& Harper PC. 1968. Shrinkage of bill width in skins of some Pachyptila species. Ibis 110: 100-102.

Lacepédè BGE. 1799. Tableaux méthodiques des mammifères et des oiseaux. Premières edition, 3ème partie, Tablue des sous-classes, divisions,sousdivisions, orders et genres des oiseaux. Paris, France.

Le S, Josse J \& Husson F. 2008. FactoMineR: An R Package for Multivariate Analysis. Journal of Statistical Software 25: 1-18.

Lloyd BD \& Powlesland RG. 1993. The decline of Kakapo Strigops habroptilus and attempts at conservation by translocation. Biological Conservation 69: 75-85.

Manly BFJ, McDonald LL, Thomas DL, McDonald TL \& Erickson WP. 2002. Resource selection by animals; Statistical design and analysis for field studies. Second Edition. Springer, Dordrecht, Netherlands.

Marchant S \& Higgins PJ. 1990. Handbook of Australian, New Zealand \& Antarctic birds. Volume 1, ratites to ducks, part A, ratites to petrels. Oxford University Press, Melbourne, Australia.

Maree BA, Wanless RM, Fairweather TP, Sullivan BJ \& Yates 0. 2014. Significant reductions in mortality of threatened seabirds in a South African trawl fishery. Animal Conservation 17: 520-529.

Markwell TJ \& Daugherty CH. 2002. Invertebrate and lizard abundance is greater on seabird-inhabited islands than on seabird-free islands in the Marlborough Sounds, New Zealand. Ecoscience 9: 293-299. 
May RM. 1990. Taxonomy as destiny. Nature 347: 129-130.

Middleton A. 2007. Two hundred years on Codfish Island (Whenuahou). Department of Conservation, Invercargill, New Zealand.

Miskelly CM \& Taylor GA. 2004. Establishment of a colony of Common Diving Petrels (Pelecanoides urinatrix) by chick transfers and acoustic attraction. Emu 104: 205-211.

Miskelly CM (ed.). 2013. New Zealand Birds Online.www.nzbirdsonline.org.nz (downloaded on 24 September 2015).

Miskelly CM, Taylor GA, Gummer H \& Williams R. 2009. Translocations of eight species of burrow-nesting seabirds (genera Pterodroma, Pelecanoides, Pachyptila and Puffinus: Family Procellaridae). Biological Conservation 142: 1965 - 1980.

Moller H, Frampton C, Hocken AG, McLean IG, Saffer V \& Sheridan L. 2000. The importance of seabird research for New Zealand. New Zealand Journal of Zoology 27: 255-260.

Moore P \& Davis A. 2004. Marram grass Ammophila arenaria removal and dune restoration to enhance nesting habitat of Chatham Island Oystercatcher Haematopus chathamensis, Chatham Islands, New Zealand. Conservation evidence 1: 8-9.

Mougeot F \& Bretagnolle V. 2000. Predation risk and moonlight avoidance in nocturnal seabirds. Journal of Avian Biology 31: 376-386.

Moyle RG, Oliveros CH, Andersen MJ, Hosner PA, Benz BW, Manthey JD, Travers SL, Brown RM \& Faircloth BC. 2016. Tectonic collision and uplift of Wallacea triggered the global songbird radiation. Nature Communications 7.

Murphy AL, Silberbauer RB, Streeter RE, Smiley DR, Smith AR, Darling S, van Essen PR \& Rapson GL. 2012. An unusual climbing dune, Big Hellfire Pass, Stewart Island, New Zealand: Exploration through environment, vegetation and trait patterns. New Zealand Journal of Botany 50: 233-256.

Murphy RC \& Harper F. 1916. Two new diving petrels. Bulletin of the American Museum of Natural History 35: 65-68.

Myers N, Mittermeier RA, Mittermeier CG, Gustavo AB, DA Fonseca GA \& Kent J. 2000. Biodiversity hotpots for conservation priorities. Nature 403: 853-858. 
Onley D \& Scofield P. 2007. Albatrosses, Petrels and Shearwaters of the world. Helm Field Guides. Bloomsbury Publishing, London, U.K.

Paleczny M, Hammill E, Karpouzi V \& Pauly D. 2015. Population trend of the world's monitored seabirds, 1950-2010. PLoS ONE 10(6): e0129342. doi: 10.1371/journal.pone.0129342.

Paterson AM, Wallis LJ \& Wallis GP. 2000. Preliminary molecular analysis of Pelecanoides georgicus (Procellariiformes: Pelecanoididae) Whenua Hou (Codfish Island): implications for its taxonomic status. New Zealand Journal of Zoology 27: 415 - 423.

Payne MR \& Prince PA. 1979. Identification and breeding biology of the diving petrels Pelecanoides georgicus and P. urinatrix exsul at South Georgia. New Zealand Journal of Zoology 6: 299-318.

Phillips RA. 2010. Eradications of invasive mammals from islands: why, where, how and what next? Emu 110: 1-7.

Penhallurick J \& Wink M. 2004. Analysis of the taxonomy and nomenclature of the Procellariiformes based on complete nucleotide sequences of the mitochondrial cytochrome b gene. Emu 104: 125-147.

Pimm SL, Russell GJ, Gittleman JL \& Brooks TM. 1995. The future of biodiversity. Science 269: 347-350.

Quinn G \& Keough M. 2002. Experimental design and data analysis for biologists. Cambridge University Press, Cambridge, U.K.

R Development Core Team. 2016. R: A language and environment for statistical computing. Vienna, Austria, R Foundation for Statistical Computing (version 3.2.4). http://www.Rproject.org/.

Rawlence NJ, Scofield RP, Spencer HG, Lalas C, Easton LJ, Tennyson AJD, Adams M, Pasquet E, Fraser C, Waters JM \& Kennedy M. 2016. Genetic and morphological evidence for two species of Leucocarbo shag (Aves, Pelecaniformes, Phalacrocoracidae) from southern South Island of New Zealand. Zoological Journal of the Linnean Society 177: 676-694.

Rayner MJ, Gaskin CP, Fitzgerald NB, Baird KA, Berg MM, Boyle D, Joyce L, Landers TJ, Loh GG, Maturin S, Perrimen L, Scofield RP, Simm J, Southey I, Taylor GA, Tennyson AJD, Robertson BC, Young M, Walle R \& Ismar SMH. 2015. Using 
miniaturised radiotelemetry to discover the breeding grounds of the endangered New Zealand Storm Petrel Fregetta maoriana. Ibis 157: 754-766.

Rayner MJ, Parker KA \& Imber MJ. 2008. Population census of Cook's Petrel Pterodroma cookii breeding on Codfish Island (New Zealand) and the global conservation status of the species. Bird Conservation International 18: 211-218.

Rheindt FE \& Austin JJ. 2005. Major analytical and conceptual shortcomings in a recent taxonomic revision of the Procellariiformes - a reply to Penhallurick and Wink (2004). Emu 105: 181-186.

Robb M, Mullarney K \& The Sound Approach. 2008. Petrels night and day. A Sound Approach Guide. The Sound Approach, Dorset, U.K.

Robertson HA, Dowding JE, Elliott GP, Hitchmough RA, Miskelly CM, O’Donnel CFJ, Powlesland RG, Sagar PM, Scofield RP \& Taylor GA. 2013. Conservation status of New Zealand birds, 2012. Department of Conservation. Wellington, New Zealand.

Rodrigues P, Aubrecht C, Gil A, Longcore T \& Elvidge C. 2012. Remote sensing to map influence of light pollution on Cory's Shearwater in Sao Miguel Island, Azores Archipelago. European Journal of Wildlife Restoration 58: 147-155.

Rodriguez A, Garcia D, Rodriguez B, Cardona E, Parpal L \& Pons P. 2015. Artificial lights and seabirds: is light pollution a threat for the threatened Balearic Petrels? Journal of Ornithology 156: 893-902.

Rollinson DP, Dilley BJ \& Ryan PG. 2014. Diving Behaviour of White-Chinned Petrels and its relevance for mitigating longline bycatch. Polar Biology 37: 1301-1308.

Rothstein HR, Sutton AJ \& Borenstein M (eds.). 2006. Publication bias in meta-analysis - Prevention, assessment and adjustments. John Wiley \& Sons Ltd., Chichester, U.K.

Sagar RL, Dunphy BJ, Stanley MC \& Rayner MJ. 2016. Nobody suspects the teal: mortality events in burrow nesting seabird chicks as a result of attacks by Campbell Island Teal. Poster presentation, Birds NZ Conference 2016, Napier, New Zealand.

Sangster G, King BF, Verbelen P \& Trainor CR. 2013. A new owl species of the genus Otus (Aves: Strigidae) from Lombok, Indonesia. PLoS ONE 8: e53712. doi:10.1371/journal.pone.0053712. 
Sangster G, Rodríguez-Godoy F, Roselaar CS, Robb MS \& Luksenburg JA. 2016. Integrative taxonomy reveals Europe's rarest songbird species, the Gran Canaria Blue Chaffinch Fringilla polatzeki. Journal of Avian Biology 47: 159-166.

Sangster G. 2014. The application of species criteria in avian taxonomy and its implications for the debate over species concepts. Biological Reviews 89: 199214.

Satterthwaite WH \& Mangel M. 2012. Behaviour models as a common framework to predict impacts of environmental change on seabirds and fur seals. Deep sea research part II: Topical studies in oceanography 65: 304-315.

Scofield P \& Stephenson B. 2013. Birds of New Zealand: A photographic guide. Auckland University Press, Auckland, New Zealand.

Seddon PJ, Griffiths CJ, Soorae PS \& Armstrong DP. 2014. Reversing defaunation: Restoring species in a changing world. Science 345: 406-412.

Sekercioglu CG, Daily CD \& Ehrlich PR. 2004. Ecosystem consequences of bird declines. Proceedings of the National Academy of Science of the United States of America 101: 18042-18047.

Shaffer SA, Weimerskirch H \& Costa DP. 2001. Functional significance of sexual dimorphism in Wandering Albatrosses, Diomedea exulans. Functional Ecology 15: 203-210.

Steiner UK \& Gaston AJ. 2005. Reproductive consequences of natal dispersal in a highly philopatric seabird. Behavioral Ecology 16: 634-639.

Sullivan W \& Wilson KJ. 2001. Use of burrow flaps to minimise interference to Chatham Petrel (Pterodroma axillaris) chicks by Broad-Billed Prions (Pachyptila vittata). New Zealand Journal of Ecology 25: 71-75.

Swann DE, Kawanashi K \& Palmer J. 2011. Evaluating types and features of camera traps in ecological studies: A guide for researchers. In: O'Connel AF, Nichols JD \& Karanth KU. (eds.). Camera traps in animal ecology; methods and analysis. Springer, Tokyo, Japan.

Sykes MT \& Wilson JB. An experimental investigation into the response of New Zealand sand dune species to different depths of sand burial. Acta Botanica Neerlandica 39: 171-181. 
Taylor G \& Cole R. 2002. South Georgian Diving Petrel (Pelecanoides georgicus) survey, Codfish Island/Whenua Hou. Department of Conservation, Wellington, New Zealand.

Taylor G, Cockburn S, Palmer D \& Liddy P. 2012. Breeding activity of Chatham Island Taiko (Pterodroma magantae) using PIT tag recorders. New Zealand Journal of Ecology 36: 425-432.

Taylor GA. 2000. Action Plan for Seabird Conservation in New Zealand. Department of Conservation, Wellington, New Zealand.

Taylor GA. 2013. South Georgian diving petrel. In: Miskelly CM (ed.). New Zealand Birds Online. www.nzbirdsonline.org.nz (downloaded on 20 May 2016).

Tennyson AJD, Cooper JH \& Shepherd LD. 2015. A new species of extinct Pterodroma petrel (Procellariiformes: Procellariidae) from the Chatham Islands, New Zealand. Bulletin of the British Ornithologists' Club 135: 267-277.

Tobias JA, Seddon N, Spottiswoode CE, Pilgrim JD, Fishpool LDC \& Collar NJ. 2010. Quantitative criteria for species delimitation. Ibis 152: 724-746.

Torchiano M. 2016. effsize: Efficient Effect Size Computation (version 0.6.2). https://CRAN.R-project.org/package=effsize.

Towns DR \& Broome KG. 2003. From small Maria to massive Campbell: forty years of rat eradications from New Zealand islands. New Zealand Journal of Zoology 30: 377-398.

Trainor S. 2008. Codfish Island South Georgian Diving Petrel: a summary of field observations 2004-2007 and recommendations for future management. Department of Conservation, Invercargill, New Zealand.

Trainor S. 2009. South Georgian Diving Petrel: a summary of field observations 20072009 on Codfish Island. Department of Conservation, Invercargill, New Zealand.

Tuck GN, Polacheck T \& Bulman CM. 2003. Spatio-temporal trends of longline fishing effort in the Southern Ocean and implications for seabird bycatch. Biological Conservation 114: 1-27.

Warham J. 1996. The behaviour, population biology and physiology of the petrels. Academic Press, London, U.K.

Watanuki Y. 1986. Moonlight avoidance behavior in Leach's Storm-Petrels as a defence against Slaty-Backed Gulls. The Auck 103: 14-22. 
Waugh SM, Barbraud C, Adams L, Freeman AND, Wilson KJ, Wood G, Landers TJ \& Baker GB. 2015. Modelling the demography and population dynamics of a subtropical seabird, and the influence of environmental factors. The Condor 117: $147-164$.

West J \& Imber MJ. 1989. Surveys of South Georgian Diving Petrels (Pelecanoides georgicus) on Codfish Island. Notornis 36: 157-158.

Wickes C \& Rance R. 2010. Sealers Bay - Whenua Hou Dune restoration pest plant review. Department of Conservation, Invercargill, New Zealand.

Wickham H. 2009. ggplot2: Elegant graphics for data analysis. Springer, New York, U.S.A.

Wilcox C, van Sebille E \& Hardesty BD. 2015. Threat of plastic pollution to seabirds is global, pervasive, and increasing. Proceedings of the National Academy of Science of the United States of America 112: 11899-11904.

Wilson H. 2009. Field guide: Stewart Island plants. Manuka Press. Cromwell, New Zealand.

Wood JR \& Briden S. 2008. South Georgian Diving Petrel (Pelecanoides georgicus) bones from a Maori midden in Otago Peninsula, New Zealand. Notornis 55: 4647.

Wood JR, Lawrence HA, Scofield R, Taylor GA, Lyver PO \& Gleeson DM. 2016. Morphological, behavioural, and genetic evidence supports reinstatement of full species status for the Grey-faced Petrel, Pterodroma macroptera gouldi (Procellariiformes, Procellariidae). Zoological Journal of the Linnean Society. DOI: $10.1111 /$ zoj.12432.

Worthy, TH. 1998. Fossils indicate Pelecanoides georgicus had large colonies at Mason Bay, Stewart Island, New Zealand. Notornis 45: 229-246.

Zangmeister JL, Hausmann MF, Cerciara J \& Mauck RA. 2009. Incubation failure and nest abandonment by Leach's Storm-petrels detected using PIT tags and temperature loggers. Journal of Field Ornithology 80: 373-379. 


\section{APPENDICES}

Appendix 1. References used to construct databases on threats and conservation actions of New Zealand's Procellariiformes (Appendix 2 \& 3).

1. Abraham ER \& Thompson FN. 2011. Estimated capture of seabirds in New Zealand trawl and longline fisheries, 2002-03 to 2008-09. New Zealand Aquatic Environment and Biodiversity Report No. 79. Ministry of Fisheries, Wellington, New Zealand.

2. Abraham ER \& Thompson FN. 2011. Summary of the capture of seabirds, marine mammals, and turtles in New Zealand commercial fisheries, 1998-99 to 2008-09. New Zealand Aquatic Environment and Biodiversity Report No. 80. Ministry of Fisheries, Wellington, New Zealand.

3. Anonymous. 2006. Predator control key to Chatham seabird success. World Birdwatch 28: 4.

4. Anonymous. 2007. Chatham Albatross slaughter. World Birdwatch 29: 3.

5. Anonymous. 2007. New shearwater colony for Kaikoura. Forest and Bird: 10.

6. Baird SJ \& Smith MH. 2007. Incidental capture of seabird species in commercial fisheries in New Zealand waters, 2003-2004 and 2004-2005. New Zealand Aquatic Environment and Biodiversity Report (9). Ministry of Fisheries, Wellington, New Zealand.

7. Baker GB, Double MC, Gales R, Tuck GN, Abbott CL, Ryan PG, Petersen SL, Robertson CJR \& Alderman R. 2007. A global assessment of the impact of fisheries-related mortality on shy and white-capped Albatrosses: Conservation implications. Biological Conservation 137: 319-333.

8. Bell E. 2002. Grey Petrels (Procellaria cinerea) on Antipodes Island, New Zealand: research feasibility, April-June 2001. Department of Conservation, Wellington, New Zealand.

9. Bell EA, Sim JL \& Scofield P. 2007. Demographic parameters of the Black Petrel (Procellaria parkinsoni). Department of Conservation, Wellington, New Zealand. 
10. Bell EA, Sim JL \& Scofield P. 2009. Population parameters and distribution of the Black Petrel (Procellaria parkinsoni), 2005/06. Department of Conservation, Wellington, New Zealand.

11. Bell EA, Sim JL \& Scofield P. 2011. Population parameters and distribution of the Black Petrel (Procellaria parkinsoni) on Great Barrier Island (Aotea Island), 2007/08. Department of Conservation, Wellington, New Zealand.

12. Bell M, Bell BD \& Bell EA. 2005. Translocation of Fluttering Shearwater (Puffinus gavia) chicks to create a new colony. Notornis 52: 11-15.

13. BirdLife International. 2004. Tracking ocean wanderers: the global distribution of albatrosses and petrels. BirdLife International, Cambridge, U.K.

14. Booth AM, Minot EO, Imber MJ \& Fordham RA. 2000. Aspects of the breeding ecology of the North Island Little Shearwater Puffinus assimilis haurakiensis. New Zealand Journal of Zoology 27: 335-345.

15. Booth AM, Minot EO, Fordham RA \& Imber MJ. 2008. Co-ordinated food provisioning in the Little Shearwater Puffinus assimilis haurakiensis: a previously undescribed foraging strategy in the Procellariidae. Ibis 142: 144146.

16. Broekhuizen N, Stahl JC \& Sagar PM. 2003. Simulating the distribution of Southern Buller's Albatross using an individual-based population model. Journal of Applied Ecology 40: 678-691.

17. Buxton RT, Anderson D, Moller H, Jones CJ \& Lyver PO. 2015. Release of constraints on nest-site selection in burrow-nesting petrels following invasive rat eradication. Biological Invasions 17: 1453-1470.

18. Buxton RT, Currey CA, Lyver PO \& Jones CJ. 2013. Incidence of plastic fragments among burrow-nesting seabird colonies on offshore islands in northern New Zealand. Marine Pollution Bulletin 74: 420-424.

19. Buxton RT, Jones CJ, Moller H \& Lyver PO. 2015. One method does not suit all: variable settlement responses of three procellariid species to vocalisation playbacks. Emu 115: 126-136.

20. Childerhouse S, Robertson C, Hockly W \& Gibbs N. 2003. Royal Albatross (Diomedea epomophora) on Enderby Island, Auckland Islands. Department of Conservation, Wellington, New Zealand. 
21. Christopher JJ, Lyver PO, Macleod CJ, Whitehead AL \& Forrester GJ. 2015. Variation in productivity of Grey-faced Petrels (Pterodroma gouldi) with local burrow density and breeding island. Emu 115: 20-28.

22. Clucas RJ, Fletcher DJ \& Moller H. 2008. Estimates of adult survival rate for three colonies of Sooty Shearwater (Puffinus griseus) in New Zealand. Emu 108: 237-250.

23. Cole R. 2004. Summary of South Georgian Diving Petrel field observations for 2003/04, Codfish Island/Whenua Hou. Department of Conservation, Invercargill, New Zealand.

24. Corkery I, Bell BD \& Nelson NJ. 2015. Is the breeding behaviour of nesting seabirds influenced by the presence of a predatory reptile-the tuatara? Journal of the Royal Society of New Zealand 45: 21-30.

25. Cuthbert R \& Davis LS. 2002. Adult survival and productivity of Hutton's Shearwaters. Ibis 144: 423-432.

26. Cuthbert R \& Sommer E. 2002. Home range, territorial behaviour and habitat use of stoats (Mustela erminea) in a colony of Hutton's Shearwater (Puffinus huttoni), New Zealand. New Zealand Journal of Zoology 29: 149160.

27. Cuthbert R, Fletcher D \& Davis LS. 2001. A sensitivity analysis of Hutton's Shearwater: prioritizing conservation research and management. Biological Conservation 100: 163-172.

28. Cuthbert R. 2001. Conservation and ecology of Hutton's Shearwater (Puffinus huttoni). Department of Conservation, Wellington, New Zealand.

29. Department of Conservation. 2002. Conservation Services Levy compendium: monitoring Wandering Albatrosses at Auckland and Antipodes Islands, 1995/96-2001/02. Department of Conservation, Wellington, New Zealand.

30. Department of Conservation. 2004. National plan of action to reduce the incidental catch of seabirds in New Zealand fisheries. Department of Conservation, Wellington, New Zealand.

31. Department of Conservation. 2007. A World first: Chatham Island Taiko fledge from predator-proof site. Department of Conservation, Wellington, New Zealand. 
32. Deppe L, McGregor KF, Tomasetto F, Briskie JV \& Scofield RP. 2014. Distribution and predictability of foraging areas in breeding Chatham Albatrosses Thalassarche eremita in relation to environmental characteristics. Marine Ecology Progress Series 498: 287-301.

33. Dunphy BJ, Taylor GA, Landers TJ, Sagar RL, Chilvers BL, Ranjard L \& Rayner MJ. 2015. Comparative seabird diving physiology: first measures of haematological parameters and oxygen stores in three New Zealand Procellariiformes. Marine Ecology Progress Series 523: 187-198.

34. Fallwell C. 2010. Home away from home. Forest and Bird 338: 16-18.

35. Francis RICC \& Bell EA. 2010. Fisheries risks to population viability of Black Petrel (Procellaria parkinsoni). Ministry of Primary Industries, Wellington, New Zealand.

36. Francis RICC \& Sagar PM. 2012. Modelling the effect of fishing on Southern Buller's Albatross using a 60-year dataset. New Zealand Journal of Zoology 39: 3-17.

37. Fraser M, Henderson G, Robertson CJR \& Scofield P. 2011. Population dynamics of the Chatham Mollymawk at The Pyramid, 19 November - 2 December 2010. Ministry of Primary Industries, Wellington, New Zealand.

38. Freeman AND \& Wilson KJ. 2002. Westland Petrels and hoki fishery waste: opportunistic use of a readily available resource? Notornis 49: 139-144.

39. Freeman AND, Wilson KJ \& Nicholls DG. 2001. Westland Petrels and the hoki fishery: determining co-occurrence using satellite telemetry. Emu 101: 47-56.

40. Freeman R, Dennis T, Landers T, Thompson D, Bell E, Walker M \& Guildford T. 2010. Black Petrels (Procellaria parkinsoni) patrol the ocean shelf-break: GPS tracking of a vulnerable Procellariiform seabird. PLoS ONE 5: e9236. doi: 10.1371/journal.pone.0009236.

41. Gangloff B \& Wilson KJ. 2004. Feeding frequency, meal size and chick growth in Pycroft's Petrel (Pterodroma pycrofti): preparing for chick translocations in Pterodroma species. Notornis 51: 26-32.

42. Gardner-Gee R, Rayner M \& Beggs JR. 2008. Monitoring Grey-faced Petrels (Pterodroma macroptera gouldi) in a restoration project on Motuora Island, Hauraki Gulf. Notornis 55: 184-190. 
43. Gaskin CP. 2011. Seabirds of the Kermadec region: their natural history and conservation. Department of Conservation, Wellington, New Zealand.

44. Gaze P. 2000. The response of a colony of Sooty Shearwater (Puffinus griseus) and Flesh-footed Shearwater (P. carneipes) to the cessation of harvesting and the eradication of Norway rats (Rattus norvegicus). New Zealand Journal of Zoology 27: 375-379.

45. Gummer H, Taylor G, Wilson KJ \& Rayner MJ. 2015. Recovery of the endangered Chatham Petrel (Pterodroma axillaris): A review of conservation management techniques from 1990 to 2010. Global Ecology and Conservation 3: 310-323.

46. Gummer H. 2003. Chick translocation as a method of establishing new surfacenesting seabird colonies: a review. Department of Conservation, Wellington, New Zealand.

47. Gummer H. 2005. Chatham Petrel (Pterodroma axillaris) management guidelines. Department of Conservation, Chatham Islands.

48. Imber M, Harrison M \& Harrison J. 2000. Interactions between petrels, rats and rabbits on Whale Island, and effects of rat and rabbit eradication. New Zealand Journal of Ecology 24: 153-160.

49. Imber MJ \& Stephenson BM. 2008. Sightings and capture of Kermadec Storm Petrels (Pelagodroma marina albiclunis), off Haszard Island and the Meyer Islets, Kermadec Islands, in 2004. Notornis 55: 166-170.

50. Imber MJ, Harrison M, Wood SE \& Cotter RN. 2003. An estimate of numbers of Grey-faced Petrels (Pterodroma macroptera gouldi) breeding on Moutohora (Whale Island), Bay of Plenty, New Zealand, during 1998-2000. Notornis 50: 23-26.

51. Imber MJ, McFadden I, Bell EA \& Scofield RP. 2003. Post-fledging migration, age of first return and recruitment, and results of inter-colony translocation of Black Petrels (Procellaria parkinsoni). Notornis 50: 183-190.

52. Imber MJ, Taylor GA, Tennyson AJD, Aikman HA, Scofield RP, Ballantyne J \& Crockett DE. 2005. Non-breeding behaviour of Magenta Petrels Pterodroma magentae at Chatham Island, New Zealand. Ibis 147: 758-763.

53. Imber MJ, West JA \& Cooper WJ. 2003. Cook's Petrel (Pterodroma cookii): historic distribution, breeding biology and effects of predators. Notornis 50 : 221-230. 
54. Imber MJ. 2005. Status of Kermadec Petrels (Pterodroma neglecta) on the Meyer Islets, and prospects for their re-colonisation of Raoul Island, Kermadec Group. Notornis 52: 168-169.

55. Ismar SMH, Baird KA, Gaskin CP, Taylor GA, Tennyson AJD, Rayner MJ, Bettesworth D, Fitzgerald N, Landers TJ \& Imber MJ. 2014. A case of natural recovery after the removal of invasive predators - community assemblage changes in the avifauna of Burgess Island. Notornis 61: 188-195.

56. Ismar SMH, Baird KA, Savell E \& Hauber ME. 2010. Patterns of offspring sexratio of a re-establishing population of Black-winged Petrels (Pterodroma nigripennis). Emu 110: 104-108.

57. Ismar SMH, Taylor G, Gaskin CP \& Rayner MJ. 2012. First breeding report of Black-winged Petrel (Pterodroma nigripennis) on Burgess Island, Mokohinau Group, Hauraki Gulf. Notornis 59: 167-170.

58. Jamieson SE \& Waugh SM. 2015. An assessment of recent population trends of Flesh-footed Shearwaters (Puffinus carneipes) breeding in New Zealand. Notornis 62: 8-13.

59. Jones C. 2000. Sooty Shearwater (Puffinus griseus) breeding colonies on mainland South Island, New Zealand: evidence of decline and predictors of persistence. New Zealand Journal of Zoology 27: 327-334.

60. Landers TJ, Rayner MJ, Phillips RA \& Hauber ME. 2011. Dynamics of seasonal movements by a trans-pacific migrant, the Westland Petrel. The Condor 113: 71-79.

61. Lawrence HA, Millar CD, Taylor GA, Macdonald LD \& Lambert DM. 2008. Excess of unpaired males in one of the world's most endangered seabirds, the Chatham Island Taiko Pterodroma magentae. Journal of Avian Biology 39: 359363.

62. Lyver PO, Davis J, Ngamane L, Anderson A \& Clarkin P. 2008. Hauraki Maori Matauranga for the conservation and harvest of titi, Pterodroma macroptera gouldi. Papers and Proceedings of the Royal Society of Tasmania 142: 149-159.

63. MacLeod CJ, Adams J \& Lyver P. 2008. At-sea distribution of satellitetracked Grey-faced Petrels, Pterodroma macroptera gouldi, captured on the Ruamaahua (Aldermen) Islands, New Zealand. Papers and Proceedings of the Royal Society of Tasmania 142: 73-88. 
64. Ministry of Primary Industries. 2013. National Plan of Action - 2013 to reduce the incidental catch of seabirds in New Zealand Fisheries. Ministry for Primary Industries, Wellington, New Zealand.

65. Mischler CP, Robertson CJR \& Bell EA. 2015. Gender and geographic variation in morphometrics of White-chinned Petrels (Procellaria aequinoctialis) in New Zealand and their foraging activities as determined from fisheries bycatch. Notornis 62: 63-70.

66. Miskelly CM \& Gummer H. 2013. Attempts to anchor pelagic Fairy Prions (Pachyptila turtur) to their release site on Mana Island. Notornis 60: 29-40.

67. Miskelly CM \& Taylor GA. 2004. Establishment of a colony of Common Diving Petrels (Pelecanoides urinatrix) by chick transfers and acoustic attraction. Emu 104: 205 - 211.

68. Miskelly CM, Bester AJ \& Bell M. 2006. Additions to the Chatham Islands' bird list, with further records of vagrant and colonising bird species. Notornis 53: 215-230.

69. Miskelly CM, Taylor GA, Gummer H \& Williams R. 2009. Translocations of eight species of burrow-nesting seabirds (genera Pterodroma, Pelecanoides, Pachyptila and Puffinus: Family Procellariidae). Biological Conservation 142: 1965-1980.

70. Moller H, Fletcher D, Johnson PN, Bell BD, Flack D, Bragg C, Scott D, Newman J, McKechnie S \& Lyver PO. 2000. Changes in Sooty Shearwater (Puffinus griseus) abundance and harvesting on the Rakiura Titi Islands. New Zealand Journal of Zoology 36: 325-341.

71. Moore PJ \& Bettany SM. 2005. Band recoveries of Southern Royal Albatrosses (Diomedea epomophora) from Campbell Island, 1943-2003. Notornis 52: 195205.

72. Moore PJ, Burg TM, Taylor GA \& Millar CD. 2001. Provenance and sex ratio of Black-browed Albatross, Thalassarche melanophrys, breeding on Campbell Island, New Zealand. Emu 101: 329-334.

73. Moore PJ, Charteris M \& Larsen EJ. 2008. Notes on New Zealand mammals 8. Predation on nesting Southern Royal Albatrosses Diomedea epomophora by a New Zealand sea lion Phocarctos hookeri. New Zealand Journal of Zoology 35: 201-204. 
74. Moore PJ, Larsen EJ, Charteris M \& Pryde M. 2012. Southern Royal Albatross on Campbell Island/Motu Ihupuku - solving a band injury problem and population survey, 2004-2008. Department of Conservation, Wellington, New Zealand.

75. Moore PJ. 2004. Abundance and population trends of mollymawks on Campbell Island. Department of Conservation, Wellington, New Zealand.

76. Muir DCG, Jones PD, Karlsson H, Koczansky K, Stern GA, Kannan K, Ludwig JP, Reid H, Robertson CJR \& Giesy JP. 2002. Toxaphene and other persistent organochlorine pesticides in three species of albatrosses from the north and south Pacific Ocean. Environmental Toxicology and Chemistry 21: 413-423.

77. Nicholls DG \& Robertson CJR. 2007. Assessing flight characteristics for the Chatham Albatross (Thalassarche eremita) from satellite tracking. Notornis 54: 168-179.

78. Nicholls DG, Robertson CJR \& Naef-Daenzer B. 2005. Evaluating distribution modelling using kernel functions for Northern Royal Albatrosses (Diomedea sanfordi) at sea off South America. Notornis 52: 223-235.

79. Pierce RJ. 2002. Kiore (Rattus exulans) impact on breeding success of Pycroft's Petrels and Little Shearwaters. Departement of Conservation, Wellington, New Zealand.

80. Rayner MJ, Clout MN, Stamp RK, Imber MJ, Brunton DH \& Hauber ME. 2007. Predictive habitat modelling for the population census of a burrowing seabird: a study of the endangered Cook's Petrel. Biological Conservation 138: 235-247.

81. Rayner MJ, Dunphy BJ \& Landers TJ. 2009. Grey-faced Petrel (Pterodroma macroptera gouldi) breeding on Little Barrier Island, New Zealand. Notornis 56: 222-223.

82. Rayner MJ, Gaskin CP, Fitzgerald NB, Baird KA, Berg MM, Boyle D, Joyce L, Landers TJ, Loh GG, Maturin S, Perrimen L, Scofield RP, Simm J, Southey I, Taylor GA, Tennyson AJD, Robertson BC, Young M, Walle R \& Ismar SMH. 2015. Using miniaturized radiotelemetry to discover the breeding grounds of the endangered New Zealand Storm Petrel Fregetta maoriana. Ibis 157: 754-766.

83. Rayner MJ, Gaskin CP, Stephenson BM, Fitzgerald NB, Landers TJ, Robertson BC, Scofield RP, Ismar SMH \& Imber MJ. 2013. Brood patch and sex-ratio 
observations indicate breeding provenance and timing in New Zealand Stormpetrel Fregetta maoriana. Marine Ornithology 41: 107-111.

84. Rayner MJ, Hartill BW, Hauber ME \& Phillips RA. 2010. Central place foraging by breeding Cook's Petrel Pterodroma cookii: foraging duration reflects range, diet and chick meal mass. Marine Biology 157: 2187-2194.

85. Rayner MJ, Hauber ME \& Clout MN. 2007. Breeding habitat of the Cook's Petrel (Pterodroma cookii) on Little Barrier Island (Hauturu): implications for the conservation of a New Zealand endemic. Emu 107: 59-68.

86. Rayner MJ, Hauber ME, Clout MN, Seldon MS, Van Dijken S, Bury S \& Phillips RA. 2008. Foraging ecology of the Cook's Petrel Pterodroma cookii during the austral breeding season: a comparison of its two populations. Marine Ecology Progress Series 370: 271-284.

87. Rayner MJ, Hauber ME, Steeves TE, Lawrence HA, Thompson DR, Sagar PM, Bury SJ, Landers TJ, Phillips, RA, Ranjard L \& Shaffer SA. 2011. Contemporary and historic separation of transhemispheric migration between two genetically distinct seabird populations. Nature Communications 2 .

88. Rayner MJ, Parker KA \& Imber MJ. 2008. Population census of Cook's Petrel Pterodroma cookii breeding on Codfish Island (New Zealand) and the global conservation status of the species. Bird Conservation International 18: 211218.

89. Rayner MJ, Taylor GA, Gummer HD, Phillips RA, Sagar PM, Shaffer SA \& Thompson DR. 2012. The breeding cycle, year-round distribution and activity patterns of the endangered Chatham Petrel (Pterodroma axillaris). Emu 112: 107-116.

90. Rayner MJ, Taylor GA, Thompson GR, Torres LG, Sagar PM \& Shaffer SA. 2011. Migration and diving activity in three non-breeding Flesh-footed Shearwaters Puffinus carneipes. Journal of Avian Biology 42: 266-270.

91. Richard Y \& Abraham ER. 2013. Risk of commercial fisheries to New Zealand seabird populations. New Zealand Aquatic Environment and Biodiversity Report No. 109. Ministry of Fisheries, Wellington, New Zealand.

92. Robertson CJR \& Bell EA. 2002. Autopsy report for seabirds killed and returned from New Zealand fisheries, 1 October 1998 to 30 September 1999: Birds 
returned by Ministry of Fisheries observers to the Department of Conservation. Department of Conservation, Wellington, New Zealand.

93. Robertson CJR, Bell D \& Scofield P. 2003. Population assessment of the Chatham Mollymawk at The Pyramid, December 2001. Department of Conservation, Wellington, New Zealand.

94. Robertson CJR, Bell EA, Sinclair N \& Bell BD. 2003. Distribution of seabirds from New Zealand that overlap with fisheries worldwide. Department of Conservation, Wellington, New Zealand.

95. Robertson CJR, Bell EA \& Scofield P. 2003. Autopsy report for seabirds killed and returned from New Zealand fisheries, 1 October 2000 to 30 September 2001: birds returned by Ministry of Fisheries observers to the Department of Conservation. Department of Conservation, Wellington, New Zealand.

96. Robertson CJR, Bell EA \& Scofield P. 2004. Autopsy report for seabirds killed and returned from New Zealand fisheries, 1 October 2001 to 30 September 2002: birds returned by Ministry of Fisheries observers to the Department of Conservation. Department of Conservation, Wellington, New Zealand.

97. Robertson CJR. 2000. Autopsy report for seabirds killed and returned from New Zealand fisheries, 1 January 1998 to 30 September 1998. Department of Conservation, Wellington, New Zealand.

98. Robertson G, McNeill M, Smith N, Wienecke B, Candy S \& Olivier F. 2006. Fast sinking (integrated weight) longlines reduce mortality of White-chinned Petrels (Procellaria aequinoctialis) and Sooty Shearwaters (Puffinus griseus) in demersal longline fisheries. Biological Conservation 132: 458-471.

99. Sagar PM \& Stahl JC. 2005. Increases in the numbers of breeding pairs in two populations of Buller's Albatross (Thalassarche bulleri bulleri). Emu 105: 4955.

100. Sagar PM, Amey J, Scofield RP \& Robertson CJR. 2015. Population trends, timing of breeding and survival of Salvin's Albatross (Thalassarche salvini) at Proclamation Island, Bounty Islands, New Zealand. Notornis 62: 21-29.

101. Sagar PM, Charteris, MR, Carroll JWA \& Scofield RP. 2011. Population size, breeding frequency and survival of Salvin's Albatrosses (Thalassarche salvini) at the Western Chain, The Snares, New Zealand. Notornis 58: 57-63. 
102. Sagar PM, Molloy J, Weimerskirch H \& Warham J. 2000. Temporal and agerelated changes in survival rates of Southern Buller's Albatrosses (Thalassarche bulleri bulleri) at The Snares, New Zealand, 1948-1997. Auk 117: 699-708.

103. Sagar RL, Leseberg A, Hunt K, Nakagawa K, Dunphy K \& Rayner MJ. 2015. Optimising translocation efforts of Mottled Petrels (Pterodroma inexpectata): growth, provisioning, meal size and the efficacy of an artificial diet for chicks. Emu 115: 137-145.

104. Sawyer SL \& Fogle SR. 2010. Acoustic attraction of Grey-faced Petrels (Pterodroma macroptera gouldi) and Fluttering Shearwaters (Puffinus gavia) to Young Nick's Head, New Zealand. Notornis 57: 166-168.

105. Scofield RP \& Christie D. 2002. Beach patrol records indicate a substantial decline in Sooty Shearwater (Puffinus griseus) numbers. Notornis 49: 158-165.

106. Shaffer SA, Tremblay Y, Weimerskirch H, Scott D, Thompson DR, Sagar PM, Moller H, Taylor GA, Foley DG, Block BA \& Costa DP. 2006. Migratory shearwaters integrate oceanic resources across the Pacific Ocean in an endless summer. Proceedings of the National Academy of Sciences of the United States of America 103: 12799-12802.

107. Söhle IS, Robertson CJR, Nicholls DG, Mouritsen H, Frost B \& Moller H. 2007. Satellite tracking of Sooty Shearwaters (Puffinus griseus) during their prelaying "exodus" and incubation. Notornis 54: 180-188.

108. Sommer E, Bell M, Bradfield P, Dunlop K, Gaze P, Harrow G, McGahan P, Morriset M, Walford M \& Cuthbert R. 2009. Population trends, breeding success and predation rates of Hutton's Shearwater (Puffinus huttoni): a 20 year assessment. Notornis 56: 144-153.

109. Stahl JC \& Sagar PM. 2000. Foraging strategies of southern Buller's Albatrosses Diomedea b. bulleri breeding on the Snares, New Zealand. Journal of the Royal Society of New Zealand 30: 299-318.

110. Stephenson B. 2006. First transmitters fitted to New Zealand Storm Petrels. Southern Bird: 8-9.

111. Stephenson B. 2006. Good news for Taiko. Forest and Bird 319: 15.

112. Stephenson B. 2006. New Zealand Storm-petrels captured in the Hauraki Gulf. Forest and Bird 319: 7. 
113. Stephenson BM, Flood R, Thomas B \& Saville S. 2008. Rediscovery of the New Zealand Storm Petrel (Pealeornis maoriana Mathews 1932): two sightings that revised our knowledge of storm petrels. Notornis 55: 77-83.

114. Sullivan W \& Wilson KJ. 2001. Differences in habitat selection between Chatham Petrels (Pterodroma axillaris) and Broad-billed Prions (Pachyptila vittata): implications for management of burrow competition. New Zealand Journal of Ecology 25: 65-69.

115. Sullivan W \& Wilson KJ. 2001. Use of burrow flaps to minimise interference to Chatham Petrel (Pterodroma axillaris) chicks by Broad-billed Prions (Pachyptila vittata). New Zealand Journal of Ecology 25: 71-75.

116. Taylor G \& Cole R. 2002. South Georgian Diving Petrel (Pelecanoides georgicus) survey, Codfish Island/Whenua Hou. Department of Conservation, Wellington, New Zealand.

117. Taylor G, Cockburn, S, Palmer D \& Liddy P. 2012. Breeding activity of Chatham Island Taiko (Pterodroma magentae) monitored using PIT tag recorders. New Zealand Journal of Ecology 36: 425-432.

118. Taylor GA. 2000. Action plan for seabird conservation in New Zealand. Department of Conservation, Wellington, New Zealand.

119. Taylor GA. 2008. Maximum dive depths of eight New Zealand Procellariiformes including Pterodroma species. Papers and Proceedings of the Royal Society of Tasmania 142: 189-198.

120. Tennyson AJD, Scofield RP \& Bell BD. 2003. Confirmation of Kermadec Petrels breeding on the southern Kermadec Islands. Notornis 50: 236-237.

121. Thomas B, Minot EO \& Holland JD. 2010. Fledging behaviour of juvenile Northern Royal Albatrosses (Diomedea sanfordi): a GPS tracking study. Notornis 57: 135-147.

122. Thompson D. 2010. Autopsy report for seabirds killed and returned from New Zealand fisheries, 1 October 2006 to 30 September 2007: birds returned by Ministry of Fisheries observers to the Department of Conservation. Department of Conservation, Wellington, New Zealand.

123. Thompson D. 2010. Autopsy report for seabirds killed and returned from New Zealand fisheries, 1 October 2007 to 30 September 2008: birds returned by 
Ministry of Fisheries observers to the Department of Conservation. Department of Conservation, Wellington, New Zealand.

124. Thompson D. 2010. Autopsy report for seabirds killed and returned from New Zealand fisheries, 1 October 2008 to 30 September 2009: birds returned by Ministry of Fisheries observers to the Department of Conservation. Department of Conservation, Wellington, New Zealand.

125. Torres LG, Thompson DR, Bearhop S, Votier S, Taylor GA, Sagar PM \& Robertson BC. 2011. White-capped Albatrosses alter fine-scale foraging behaviour patterns when associated with fishing vessels. Marine Ecology Progress Series 428: 289-301.

126. Trainor S. 2008. Codfish Island South Georgian Diving Petrel: a summary of field observations 2004-2007 and recommendations for future management. Department of Conservation, Invercargill, New Zealand.

127. Trainor S. 2009. South Georgian Diving Petrel: a summary of field observations 2007-2009 on Codfish Island. Department of Conservation, Invercargill, New Zealand.

128. Troup C, Sixtus CR \& Paterson AM. 2004.The long commute: Southern Royal Albatross (Diomedea epomophora) foraging trips during incubation. MSc. Thesis. Lincoln University, New Zealand.

129. Veitch CR, Miskelly CM, Harper GA, Taylor GA \& Tennyson AJD. 2004. Birds of the Kermadec Islands, south-west Pacific. Notornis 51: 61-90.

130. Wakefield ED, Phillips RA, Trathan PN, Arata J, Gales R, Huin N, Robertson G, Waugh SM, Weimerskirch H \& Matthiopoulos J. 2011. Habitat preference, accessibility, and competition limit the global distribution of breeding Blackbrowed Albatrosses. Ecological Monographs 81: 141-167.

131. Walker K \& Elliott G. 2005. Population changes and biology of the Antipodean Wandering Albatross (Diomedea antipodensis). Notornis 52: 206-214.

132. Walker K \& Elliott G. 2006. At-sea distribution of Gibson's and Antipodean Wandering Albatrosses, and relationships with longline fisheries. Notornis 53: 265-290.

133. Was N, Sullivan W \& Wilson KJ. 2000. Burrow competition between Broadbilled Prions (Pachyptila vittata) and the endangered Chatham Petrel (Pterodroma axillaris). Department of Conservation, Wellington, New Zealand. 
134. Waugh S, Troup C, Filippi D \& Weimerskirch H. 2002. Foraging zones of Southern Royal Albatrosses. Condor 104: 662-667.

135. Waugh SM, Barbraud C, Adams L, Freeman AND, Wilson KJ, Wood G, Landers TJ \& Baker GB. 2015. Modelling the demography and population dynamics of a subtropical seabird, and the influence of environmental factors. The Condor 117: 147-164.

136. Waugh SM, Cabrera H Jr, Wood GC \& Davis LS. 2003. Burrow occupancy in Westland Petrels (Procellaria westlandica). Notornis 50: 123-127.

137. Waugh SM, Doherty PF, Freeman AND, Adams L, Woods GC, Bartle JA \& Hedley GK. 2006. Demography of Westland Petrels (Procellaria westlandica), 19952003. Emu 106: 219-226.

138. Waugh SM, MacKenzie DI \& Fletcher D. 2008. Seabird bycatch in New Zealand trawl and longline fisheries 1998-2004. Papers and Proceedings of the Royal Society of Tasmania 142: 45-66.

139. Whitehead AL, Lyver PO, Jones CJ, Bellingham PL, MacLeod CJ, Coleman M, Karl BJ, Drew K, Pairman D, Gormley AM \& Duncan RP. 2014. Establishing accurate baseline estimates of breeding populations of a burrowing seabird, the Greyfaced Petrel (Pterodroma macroptera gouldi) in New Zealand. Biological Conservation 169: 109-116.

140. Wickes C \& Rance R. 2010. Sealers Bay - Whenua Hou Dune Restoration Pest Plant Review. Department of Conservation, Invercargill, New Zealand.

141. Wiltshire A \& Hamilton S. 2003. Population estimate for Northern Giant Petrel (Macronectes halli) on Antipodes Island, New Zealand. Notornis 50: 128-132.

142. Wiltshire AJ \& Scofield RP. 2000. Population estimate of breeding Northern Giant Petrels Macronectes halli on Campbell Island, New Zealand. Emu 100: 186-191.

143. Wood GC \& Otley HM. 2013. An assessment of the breeding range, colony sizes and population of the Westland Petrel (Procellaria westlandica). New Zealand Journal of Zoology 40: 186-195.

144. Young M \& Adams NJ. 2010. Plastic debris and seabird presence in the Hauraki Gulf, New Zealand. New Zealand Journal of Marine and Freshwater Research 44: 167-175. 
145. Young M. 2013. The breeding biology of Northern White-faced Storm Petrels (Pelagodroma marina maoriana) and a feeding trial in preparation for translocation, New Zealand. MSc. thesis, Massey University, New Zealand. 

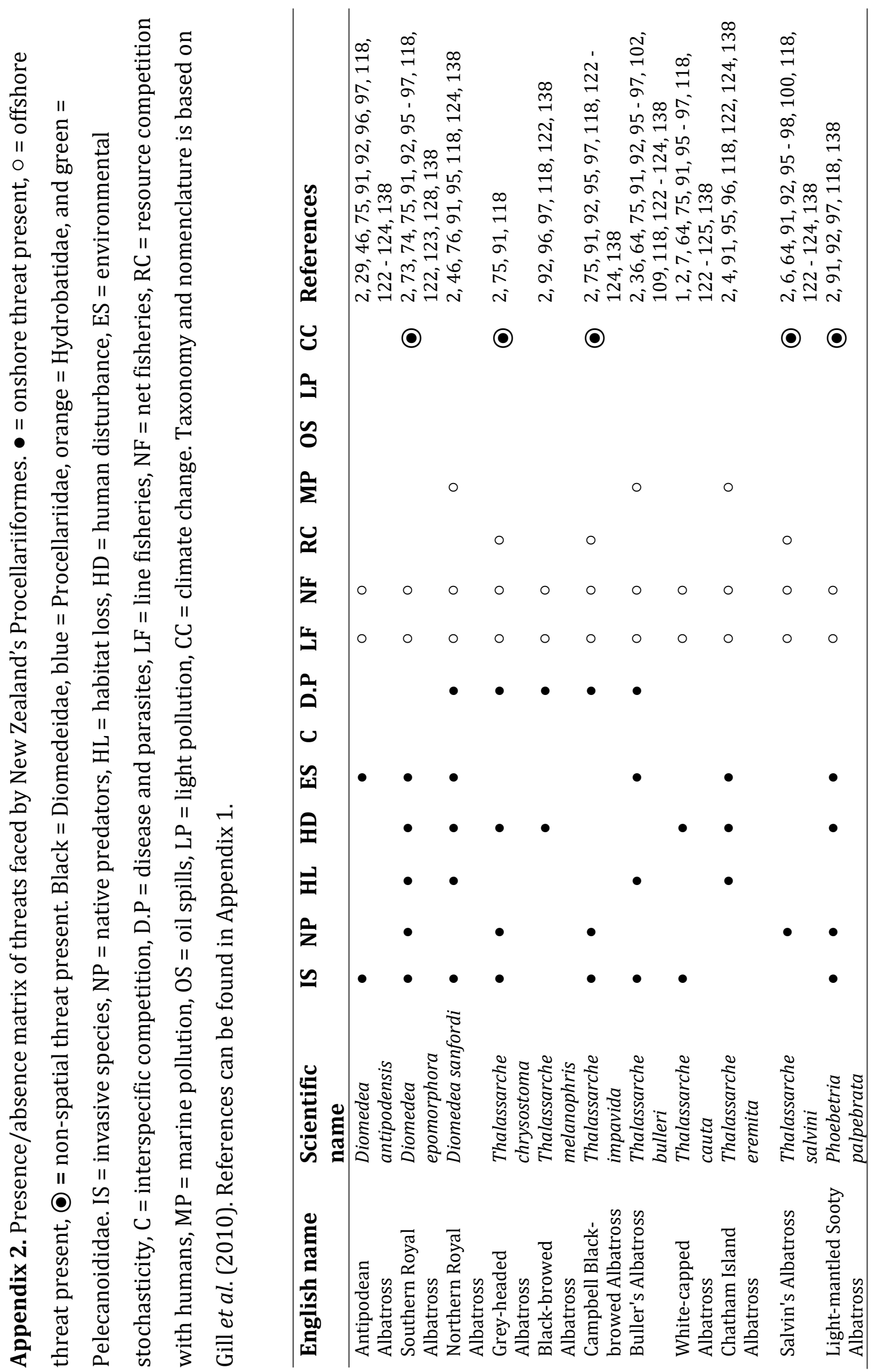


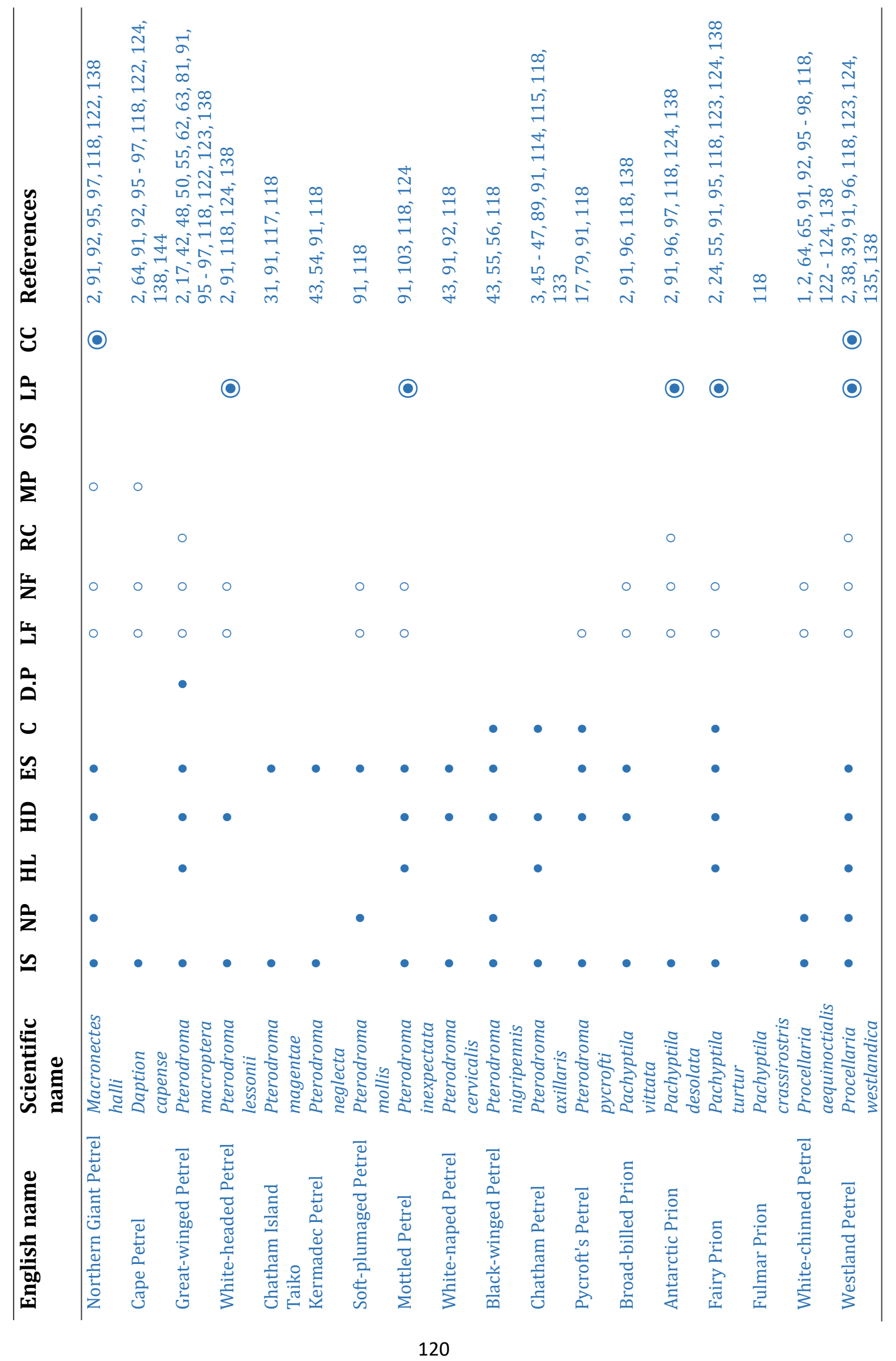




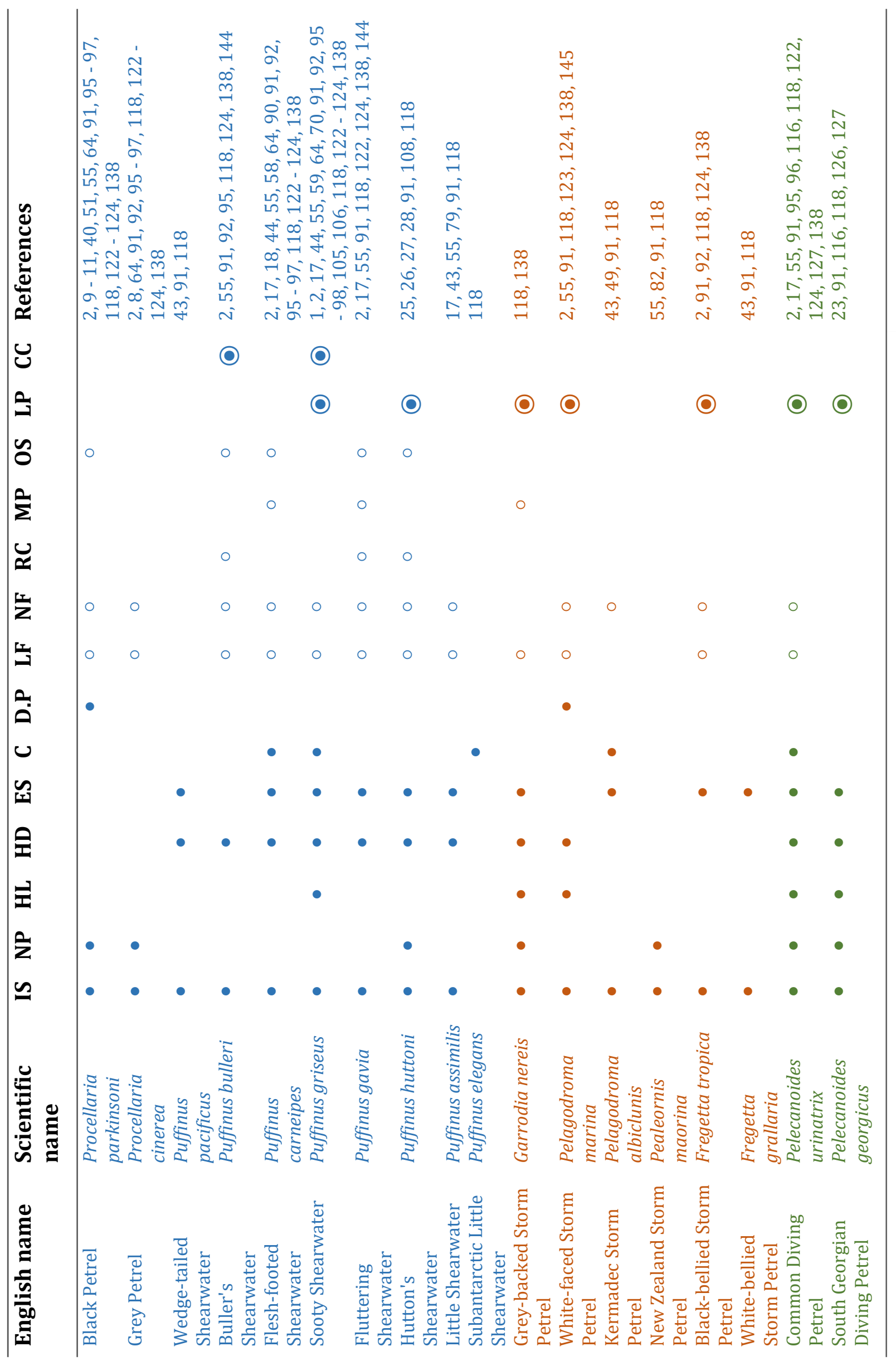



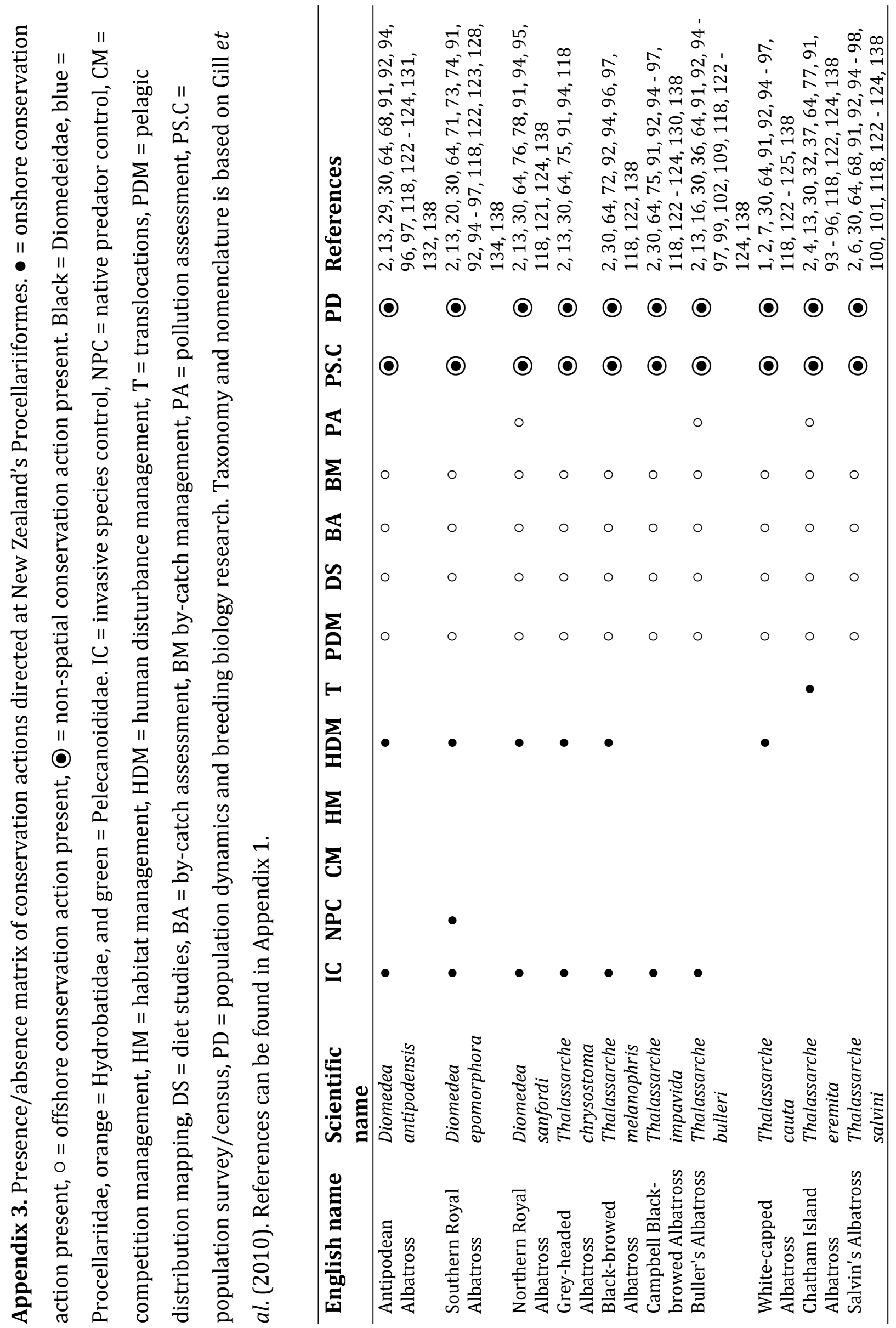


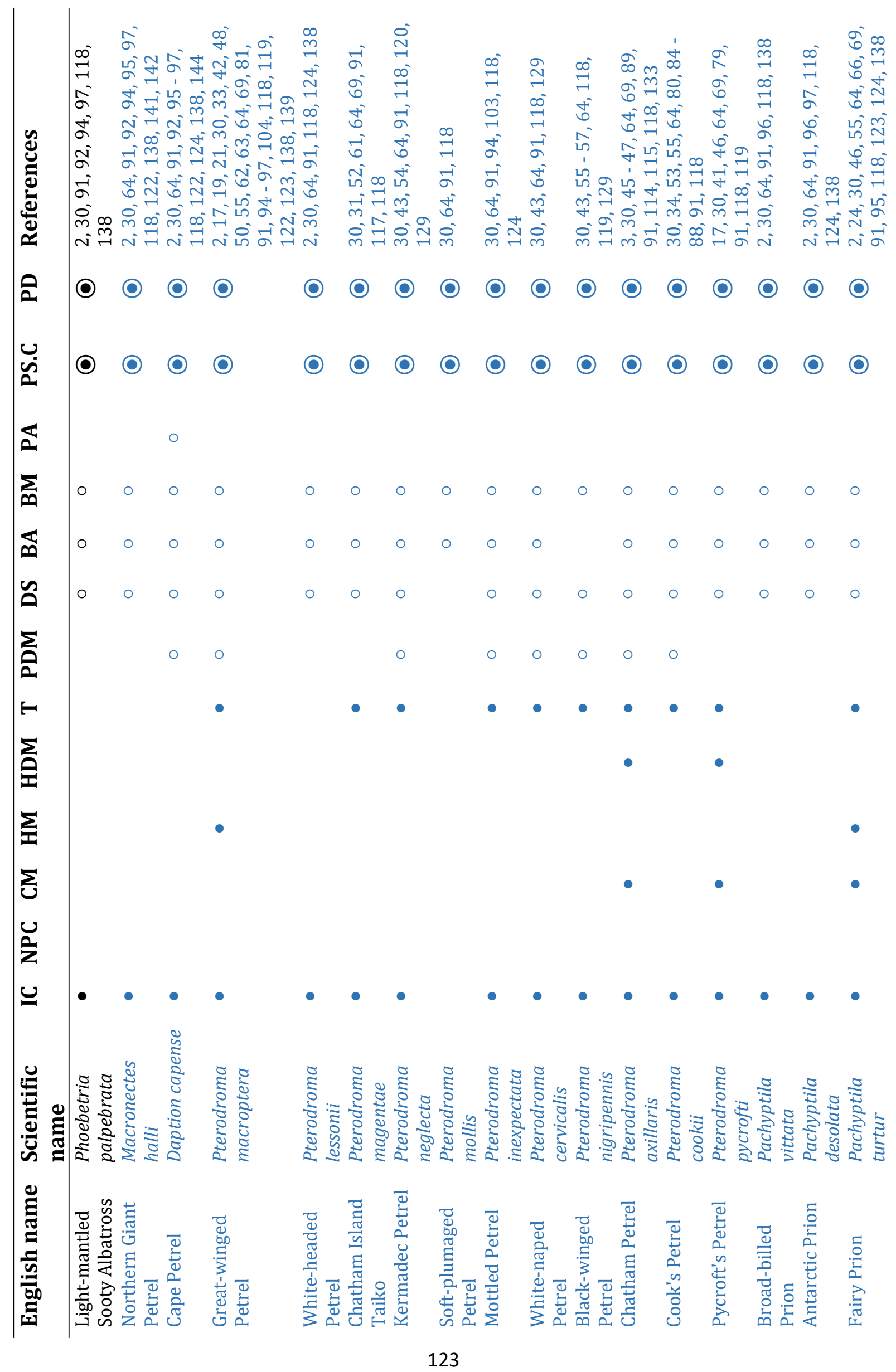




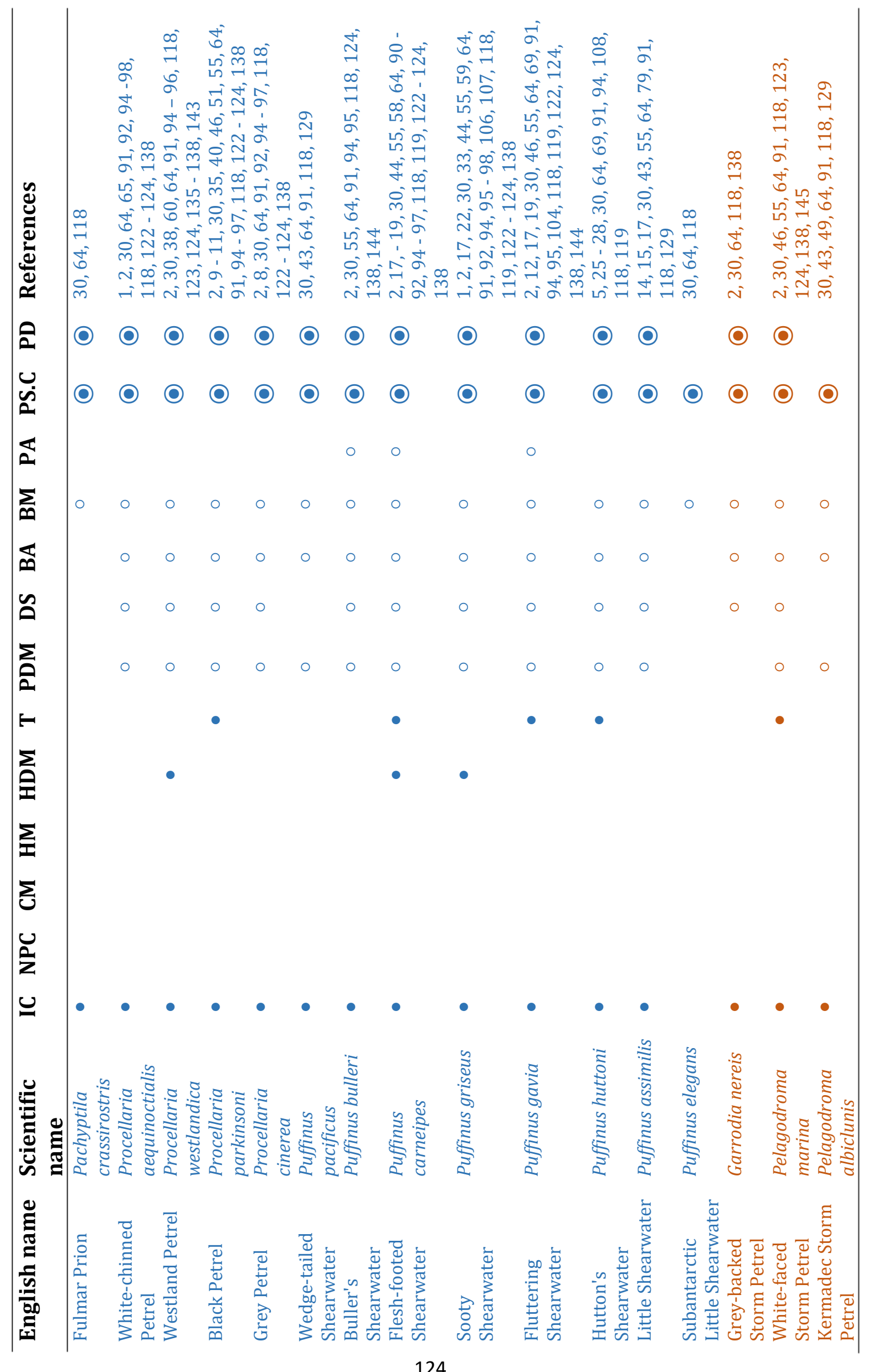




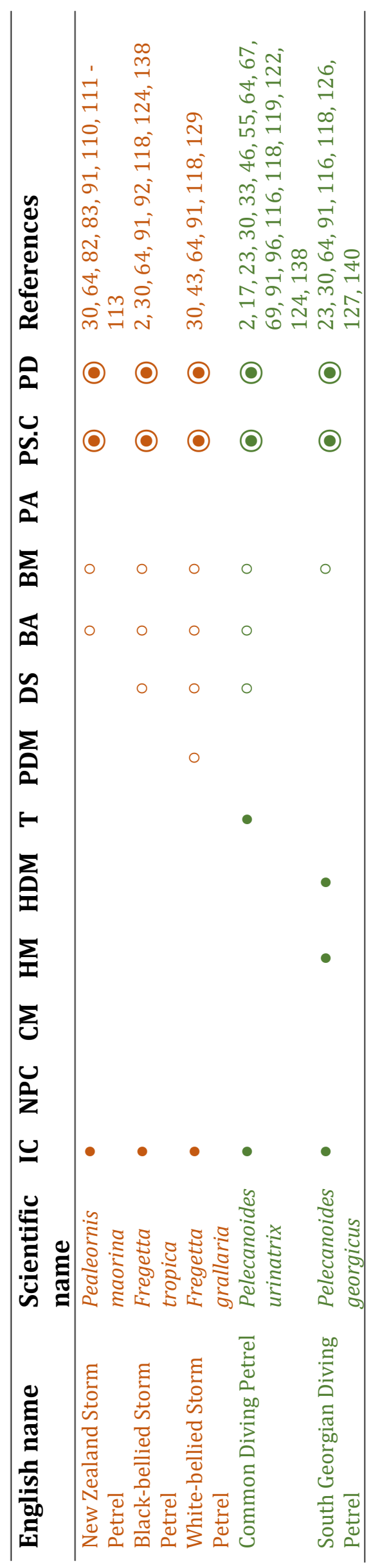




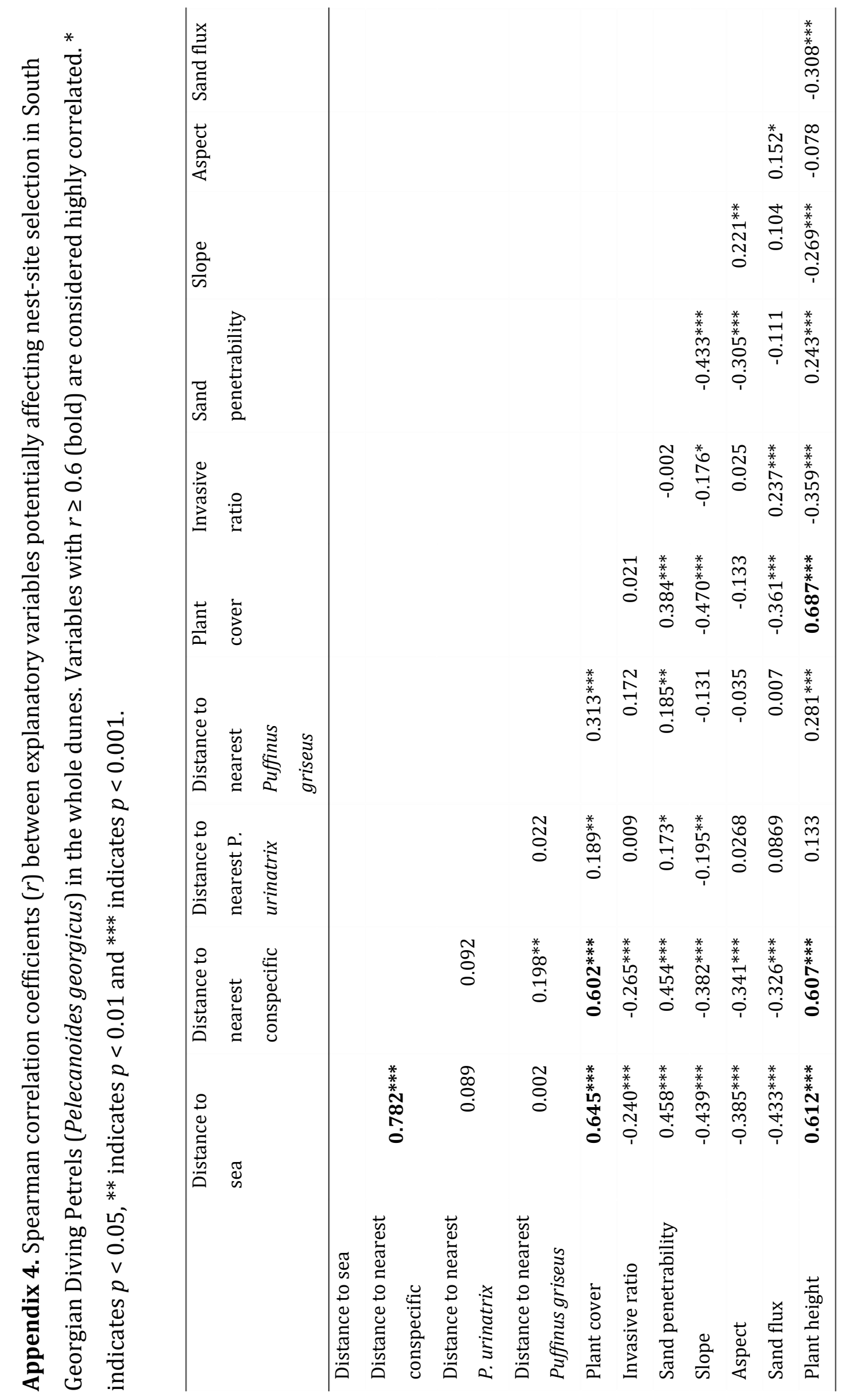




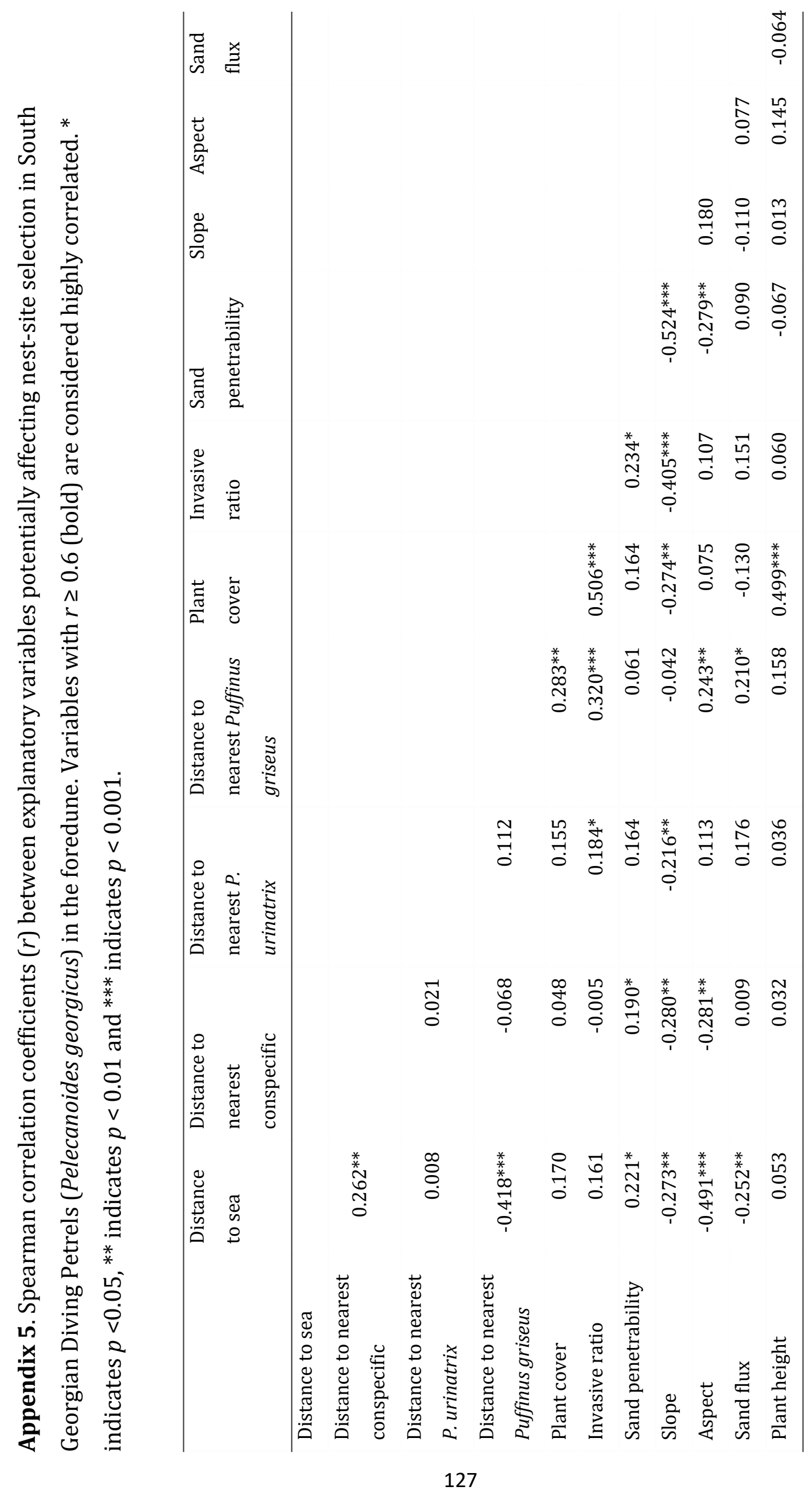

